

UNIVERSIDADE DE BRASÍLIA- UnB

Centro de Estudos Avançados Multidisciplinares - CEAM

Programa de Pós-Graduação em Desenvolvimento, Sociedade e Cooperação Internacional - PPGDSCI

Ana Beatriz Pinto de Almeida Vasconcellos

OS CAMINHOS DA SEGURANÇA ALIMENTAR E NUTRICIONAL NO BRASIL: UM ESTUDO SOBRE A IMPLEMENTAÇÃO DO SISTEMA NACIONAL DE SEGURANÇA ALIMENTAR 2004-2014

Tese apresentada ao Programa de Pós-Graduação em Desenvolvimento, Sociedade e Cooperação Internacional do Centro de Estudos Avançados Multidisciplinares da Universidade de Brasília como requisito parcial para obtenção do título de doutor em Desenvolvimento, Sociedade e Cooperação Internacional.

Orientadora: Prof. Dra. Leides Barroso de Azevedo Moura 
UNIVERSIDADE DE BRASÍLIA- UnB

Centro de Estudos Avançados Multidisciplinares - CEAM

Programa de Pós-Graduação em Desenvolvimento, Sociedade e Cooperação Internacional PPGDSCI

Ana Beatriz Pinto de Almeida Vasconcellos

\title{
OS CAMINHOS DA SEGURANÇA ALIMENTAR E NUTRICIONAL NO BRASIL: UM ESTUDO SOBRE A IMPLEMENTAÇÃO DO SISTEMA NACIONAL DE SEGURANÇA ALIMENTAR 2004-2014
}

\begin{abstract}
Tese apresentada ao Programa de Pós-Graduação em Desenvolvimento, Sociedade e Cooperação Internacional do Centro de Estudos Avançados Multidisciplinares da Universidade de Brasília como requisito parcial para obtenção do título de doutor em Desenvolvimento, Sociedade e Cooperação Internacional.
\end{abstract}

Banca Examinadora:

Profa Dra Leides Barroso Azevedo Moura (Orientadora, PPGDSCI/UnB)

Prof Dr. Umberto Euzébio (Membro Titular Interno, PPGDSCI/UnB)

Dra. Michele Lessa (Membro Titular Externo, Ministério da Saúde)

Profa Dra Denise Bontempo (Membro Titular Externo, UnB)

Profa Dra Danielle Cabrini Mattos (Membro Titular Externo, UnB)

Prof Dra Ana Maria Nogales Vasconcelos (Suplente) 
Dedico esta tese às minhas queridas filhas Thaís e Alice, e minhas netas Maria Fernanda e Helena, estrelas guias durante esta caminhada. 


\section{AGRADECIMENTOS}

Agradeço aos meus amados pais, Fernando e Ruth Vasconcellos, pelo gosto de estudar, conhecer, e duvidar sempre.

Agradeço às minhas queridas filhas, pelo amor e compreensão que demostraram sempre e que em muito me impulsionaram a seguir adiante na difícil tarefa de construir esta tese.

Agradeço as minhas amigas por estarem sempre presentes com conversas despretensiosas e alegres, que em muito me ajudaram a esfriar a cabeça, refletir e prosseguir.

Agradeço, especialmente, a amiga Carmem Laura Teixeira, pela atuação solidária e afetuosa, a qual possibilitou a minha inscrição e participação no Programa de Pós-Graduação de Desenvolvimento, Sociedade e Cooperação Internacional.

Agradeço às inúmeras colegas, parceiras eventuais e amigas que fiz durante a minha trajetória profissional na área da nutrição em saúde pública, que muito me ensinaram sobre as relações dos movimentos sociais com o Estado e com a academia e que me fizeram amar a nutrição em sua dimensão política e social.

Agradeço à minha orientadora Professora Leides Barroso de Azevedo Moura pela paciência e estimulo e à colega Rebeca Souza pelas perguntas instigantes e pela transmissão de energia positiva, característica de sua juventude.

Agradeço à minha sempre presente Professora Denise Bomtempo, pela confiança e pelo continuado incentivo que me fez adentrar na difícil esfera acadêmica.

Agradeço ao CEAM e toda sua equipe de professores por oferecer oportunidades aos projetos de pesquisa desafiadores que a perspectiva multidisciplinar do Programa de Pós-Graduação em Desenvolvimento, Sociedade e Cooperação abarca.

Agradeço à Universidade de Brasília, por ter aberto as portas à minha formação acadêmica e pessoal, e para onde sempre retorno com certeza de encontrar colegas, professores e amigos que me inspiram e motivam. 


\section{RESUMO}

A tese traçou o processo de implementação do Sistema Nacional de Segurança Alimentar e Nutricional - SISAN, reconstruindo sua trajetória no período de 2004 a 2014. Adotando referenciais teóricos da análise de políticas públicas como ciclo e com forte influência das ideias e instituições que conformam a política de segurança alimentar e nutricional no país, a pesquisa objetivou analisar o processo de implementação do SISAN em sua dimensão institucional com vistas a identificar os limites e as potencialidades dos mecanismos adotados pelo governo central para efetivar a SAN. Estudo de abordagem mista que utilizou método de revisão narrativa e integrativa de literatura, dados secundários da base de dados ESTADIC/MUNIC 2014 e dados primários por intermédio de entrevistas em profundidade com atores de SAN. O referencial teórico demonstrou que os mecanismos institucionais advêm de modelos de sistemas de políticas sociais anteriores e da aprendizagem de atores sociais e agentes do Estado em operar tais mecanismos, configurando sua trajetória dependente. A revisão integrativa identificou os antecedentes históricos da questão alimentar brasileira e sua inserção na agenda pública governamental, a construção conceitual que alicerçou o sistema, os atores e instituições envolvidas e sistema político que alavancou a Segurança Alimentar e Nutricional, os números referentes a sua descentralização e a percepção dos atores sobre sua configuração institucional. Ao descrever os antecedentes históricos e trajetória da Política de SAN e do SISAN, o reconhecimento de uma trajetória vitoriosa que encontrou eco no contexto político partidário vigente, ao assumir projeção na agenda de governo federal pós-eleições de 2002. A revisão narrativa de literatura evidenciou a construção positiva do SISAN reforçando os conteúdos de participação social e a intersetorialidade como elementos constitutivos do SISAN. A análise dos dados secundários da Pesquisa ESTADIC/MUNIC, conduzida pelo IBGE no período de 2014-2015, revelou uma baixa adesão aos critérios de adesão ao SISAN com apenas $1,7 \%$ dos municípios brasileiros estruturados para gestão da política de SAN. Com base nas entrevistas realizadas com atores de SAN foram analisadas as fragilidades que o SISAN enfrenta em adaptar os mecanismos federais de coordenação, articulação, participação e produção de consensos ao nível local, sendo que o propósito de SAN alicerçados em um projeto político partidário foi identificado como risco a expansão do sistema na medida em que dificulta a adesão de gestores locais mais distantes ou mesmo contrários a orientação do sistema. Conclui-se que a institucionalidade adotada reflete um modelo de desenvolvimento e de governança solidário, voltado a produzir transformações na base social, por intermédio de forte participação e inclusão social. Intercala-se entre as etapas de formulação e implementação, reflexões sobre o conteúdo abrangente da política e seus efeitos na pratica institucional do Estado Brasileiro, de conformação democrática liberal e não homogêneo, para o qual os mecanismos selecionados previamente são positivos, mas inacabados e insuficientes para dar completude ao SISAN.

Palavras Chaves: Política Pública, Implementação, Institucionalidade, Sistema Nacional de Segurança Alimentar e Nutricional. 
The thesis outlined the process of implementation of the National System for Food and Nutritional Security - SISAN, rebuilding your trajectory in the period 2004 to 2014. Adopting theoretical references of public policy analysis cycle and with strong influence of ideas and institutions that make up the food and nutritional security SAN policy in the country, the research aimed to analyze the process of implementation of the institutional dimension in your SISAN in order to identify the limits and potential of the mechanisms adopted by the Federal Government to implement the SAN. It was used mixed methods, cross-sectional research approach based on integrative and narrative literature review, data from the ESTADIC/MUNIC 2014, and in-depth interview. The theoretical framework has shown that institutional mechanisms arising from systems models of previous social policies and learning of social actors and State agents in operating such mechanisms, configuring your path dependent. The integrative review identified at the historical background of the Brazilian food issue, your insertion in government public agenda, conceptual construction builds the system, the actors and the actors and institutions involved, and political system that leveraged the food and nutritional security, the figures relating to decentralization and your perception of the actors on your institutional setting. When describing the historical background and the Political trajectory of SAN and SISAN, a victorious trajectory who found eco in the current partisan political context, to take projection in post-election federal government agenda of 2002. The bibliography consulted stressed the positive construction of System reinforcing the contents of social participation and intersectoral approach as constituent parts of SISAN. The theoretical analysis demonstrated that institutional mechanisms arising from systems models of previous social policies and learning of social actors and agents of the State to operate such mechanisms by setting your path dependent. Secondary data analysis Research ESTADIC/MUNIC, conducted by the IBGE in period 2014-2015, revealed a low adherence to membership criteria with only $1,7 \%$ of Brazilian municipalities structured of managing the SAN policy. Based on the interviews carried out with SAN actors, the weaknesses that SISAN faced in adapting the federal mechanisms of coordination, articulation, participation and consensus production at the local level were analyzed, and the purpose of SAN based on a party political project was identified as a risk to the expansion of the system insofar as it makes it more difficult for local managers to be more distant or even contrary to the orientation of the system.It was concluded that the institutions adopted reflects a model of development and solidarity governance, destined to produce transformations in social base through strong participation and social inclusion. Intercalate between the steps of design and implementation, reflections on the comprehensive content of the policy and its effects on institutional practice of the Brazilian State, democratic liberal and not forming homogeneous, for which the mechanisms selected previously are positive, but unfinished and insufficient to give completeness to SISAN.

Key words: Public policies, Implementation, Institutionally, Food and Nutrition Security System. 


\section{LISTA DE QUADROS}

Quadro 01 - Dimensões Institucionais da PNSAN/SISAN

Quadro 02 - Modelo Aplicado Para Revisão integrativa.

Quadro 03 - Classificação da Produção Cientifica Nacional Selecionada de acordo com Eixo Temático de SAN, 2004 - 2014.

Quadro 04 - Relação de Documentos, Leis, Decretos e Resoluções Analisadas.

Quadro 05 - Arcabouço Institucional e Propósitos do Sistema Nacional de Segurança Alimentar e Nutricional

Quadro 06 - Orçamento empenhado para cada programa da Segurança Alimentar e Nutricional (SAN) de acordo com o PPA (2012-2015).

Quadro 07. Relação Temática das Exposições de Motivos elaboradas pelo CONSEA $2004-2014$

Quadro 08 - Resoluções emitidas pela CAISAN, por assunto no período de 2009 a 2014.

Quadro 09 - Evolução temática, ideias, conceitos e categorias dos documentos das Conferências Nacionais de SAN - 2004-2015.

Quadro 10 - Detalhamento das Ideias e Síntese das Categoriais e conceitos analisados a partir das Conferências Nacionais de SAN - 2004 -2015 


\section{LISTA DE TABELAS}

Tabela 01. Estrutura de SAN no nível estadual segundo vinculação. Brasil e região. ESTADIC, 2014.

Tabela 02. Número de estados com órgão gestor, segundo a secretaria /setor que está associada ou subordinada por regiões e Brasil - 2014

Tabela 03. Número e Percentual de Estados que informam a existência de conselho, câmara e plano de SAN simultaneamente. Por regiões e Brasil. ESTADIC, 2014.

Tabela 04. Número de Estados Por Ação Desenvolvida Com Recurso Próprio. Região e Brasil - ESTADIC 2014.

Tabela 05. Relação de Secretaria e ou Setor ao qual a SAN se encontra vinculada, em número absoluto e percentual. Por municípios, região e Brasil. 2014* . 


\section{LISTA DE GRAFICOS}

Gráfico 1 - Distribuição das Notas Conferidas aos Princípios e Diretrizes do SISAN 


\section{LISTA DE SIGLAS E ABREVIATURAS}

CAISAN - Câmara Intersetorial de Segurança Alimentar e Nutricional CIAN - Comissão Interministerial de Alimentação e Nutrição

CNS - Conselho Nacional de Saúde

CNSAN - Conferência Nacional de Segurança Alimentar e Nutricional

CONSEA - Conselho Nacional de Segurança Alimentar e Nutricional

CSA - Comitê de Segurança Alimentar da FAO

DHAA - Direito Humano à Alimentação Adequada

FAO - Food and Agriculture Organization of the United Nations

FBSAN - Fórum Brasileiro de Segurança Alimentar e Nutricional FIOCRUZ

- Fundação Oswaldo Cruz

IBASE - Instituto Brasileiro de Análises Sociais e Econômicas

IBGE - Instituto Brasileiro de Geografia e Estatística

INAN - Instituto Nacional de Alimentação e Nutrição

IPEA - Instituto de Pesquisa Econômica Aplicada

LOAS - Lei orgânica de Assistência Social

LOSAN - Lei Orgânica de Segurança Alimentar e Nutricional

MAPA - Ministério da Agricultura, Pecuária e Abastecimento

MDA - Ministério do Desenvolvimento Agrário

MDS - Ministério do Desenvolvimento Social e Combate à Fome

MEC - Ministério da Educação

MESA - Ministério Extraordinário de Segurança Alimentar

MS - Ministério da Saúde

MUNIC/ESTADIC - Pesquisa de Informações Estaduais e Municipais

ONU - Organização das Nações Unidas

OXFAM - Organização Não Governamental de Defesa de Direitos de Grupos e Minorias

PAA - Programa de Aquisição de Alimentos

PAT - Programa de Alimentação do Trabalhador

PBC - Programa de Prestação de Benefício Continuada PBF - Programa

Bolsa Família

PIB - Produto Interno Bruto

PFZ - Programa Fome Zero

PLANSAN - Plano Nacional de Segurança Alimentar e Nutricional

PNAB - Política Nacional de Atenção Básica

PNAE - Programa Nacional de Alimentação Escolar

PNAN - Política Nacional de Alimentação e Nutrição

PNPS - Política Nacional de Promoção da Saúde

PNSAN - Política Nacional de Segurança Alimentar e Nutricional

PPA - Plano Plurianual

PRONAN - Programa Nacional de Alimentação e Nutrição

SAN - Segurança Alimentar e Nutricional

SISAN - Sistema Nacional de Segurança Alimentar e Nutricional

SISVAN - Sistema de Vigilância Alimentar e Nutricional

SUAS - Sistema Único de Assistência Social

SUS - Sistema Único de Saúde 


\section{Sumário}

Introdução ...................................................................................................13

Pergunta e Objetivos que orientam a Tese .............................................................19

Aproximações Conceituais e Estrutura da Tese ...................................................19

Capitulo 1 - Pressupostos Teóricos e Metodológicos.............................22

1.1. Abordagens Teóricas Sobre Análise de Políticas Publicam ......................22

1.2 Implementação e Desafios Analíticos da Política Brasileira de SAN .......30

1.3. O Referencial Neoinstitucional na Análise de Políticas Públicas ............39

1.4. Procedimentos Metodológicos e Instrumentos de Coleta.........................48

1.4.1. Delineamento da Pesquisa ................................................................................48

1.4.2. Etapas da Pesquisa..................................................................................................48

1.4.2.1. Revisão Narrativa e Revisão Integrativa de Literatura .......................49

1.4.2.1. A Pesquisa Documental e a Análise de Dados Secundários ................52

1.4.2.3 Entrevistas em Profundidade .........................................................................57

1.5. Instrumentos para Coleta de Dados..............................................................58

Capítulo 2 - Trajetória da Segurança Alimentar e Nutricional no

Brasil: uma revisão narrativa de literatura .....................................59

2.1. Antecedentes Históricos da Segurança Alimentar e Nutricional .............59

2.2. Contexto Político para Formação do SISAN................................................63

2.3. Desenho Institucional do SISAN ....................................................................65

2.4. Estado da Arte da Segurança Alimentar e Nutricional no Brasil ...........69

Capitulo 3 - Um Panorama da Descentralização do SISAN ............82

3.1. Panorama Estadual de Implantação do SISAN ............................................83

3.2. Panorama Municipal de Implantação do SISAN........................................89

3.3. Olhares Cruzados ..........................................................................................92

Capítulo 4 - Percepção dos Atores Sobre a Construção do SISAN 
4.3. Organização das Entrevistas

4.4. A Construção do SISAN - Virtudes e Fragilidades da Participação Social e da Articulação 109

4.5. A Visão Sobre A Federação. 129

4.6. Questões sobre Gestão, Orçamento e Financiamento.

4.7. Decifrando os Significados do Monitoramento

4. 8. Uma leitura de conjunto da ópera: considerações acerca dos resultados a partir das categorias

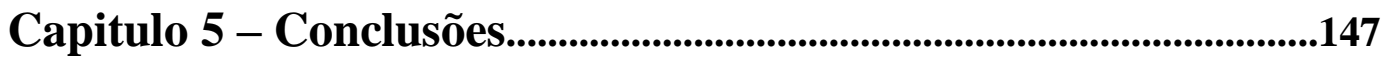

Limites da Pesquisa ...........................................................................151

Referências Bibliográficas.....................................................................152

Anexo 1 - Roteiro de Entrevista Semiestruturada.........................................166

Anexo 2 - Plano Avaliativo das Entrevistas ..............................................169 


\section{Introdução}

O título escolhido para esta tese reflete não só o objeto de trabalho, mas o próprio percurso que segui na minha na vida profissional como nutricionista e por muitos anos técnica e gestora de políticas da área da nutrição. A complexidade com que a questão alimentar é percebida e tratada pelo aparelho estatal sempre me despertou interesse, seja pelos seus muitos sentidos ou pelo acumulo de situações que necessitam ser enfrentadas.

A partir das oportunidades que tive de participar de processos que levaram a construção de programas e de políticas, mantendo a convivência com burocratas, especialistas, estudiosos, militantes e por algumas vezes com setores contrários a qualquer avanço do governo nesse campo, a ideia desta tese surgiu quase que naturalmente.

A constituição do Sistema Nacional de Segurança Alimentar e Nutricional, que busca traduzir institucionalmente um conceito multidimensional da questão alimentar e nutricional, abriu as portas para que eu pudesse tirar a ideia do papel e refletir sobre o conjunto de etapas e contextos que uma política pública engloba desde sua origem como problema social até seu ganho como agenda de governo e posterior implantação.

Assim, descrever sua trajetória, decifrar as ideias e os interesses que se colocaram em curso e elaborar um quadro analítico, que pudesse ser explicativo dos desafios enfrentados na implantação da política, foram fatores que motivaram o presente estudo. Questiona- se a suficiência dos mecanismos institucionais que o SISAN adota na expansão e consolidação de um sistema abrangente como pretendido em suas referências legais. Acerca de sua expansão, indaga-se até que ponto o SISAN existe como sistema descentralizado, onde regionalmente se mostra mais ou menos descentralizado, em que bases se organiza e quais as estruturas reproduz. Para estudar as ideias que orientaram a concepção e fundamentou sua institucionalidade, foram ouvidos atores relevantes do processo na tentativa de investigar os conteúdos explícitos e implícitos que contornam a formação do SISAN

Para situar a Segurança Alimentar e Nutricional (SAN) é preciso registrar que ela é o termo adotado internacionalmente pela Organização das Nações Unidas para Alimentação e Agricultura (FAO) para explicar, no nível global e local, a 
dimensão social que relaciona a produção agrícola e o acesso aos alimentos por parte dos países e das pessoas.

O conceito de "segurança alimentar", estabelecido no pós-guerra, evoluiu nas últimas décadas, refletindo as mudanças de paradigmas presentes na interpretação da questão da fome como fenômeno social e do acesso aos alimentos. Passando da necessidade de dispor de excedentes agrícolas para enfrentar crises e períodos de guerra, para a noção de alimento como desenvolvimento, fundamentou as ajudas alimentares dos países ricos aos demais países, até alcançar uma versão múltipla de significados onde a noção do global e nacional, do acesso individual e familiar, de indicadores objetivos para uma percepção subjetiva da fome e da falta de acesso de alimentos, encontram-se interligados, adensando a complexidade do conceito.

O termo segurança nutricional, por sua vez, aparece internacionalmente, somente nos anos noventa, enfatizando o papel do consumo individual e familiar como componente da questão alimentar, disseminando o conceito de segurança alimentar e nutricional, mundialmente, na perspectiva de consolidar, por meio do conceito reformulado, a abrangência com que a esfera da alimentação e nutrição se manifesta na vida humana (SHETY, 2015).

Interessante observar que na análise de Carolan (2014) acerca da evolução do conceito de SAN, são demarcadas categorias que sinalizam para o entendimento de como o problema alimentar mundial foi tratado no decorrer dos anos. De um período marcado pela "calorização" da segurança alimentar, cuja solução passava simplesmente pela necessidade da agricultura de produzir mais, vivenciou-se, em seguida, a "neoliberalização" da segurança alimentar, com a disseminação da ideia de que os países não precisavam produzir de tudo na esfera alimentar, uma vez que o comercio internacional, por si só garantiria a oferta de alimentos a todos. Concomitantemente chegou-se ao ápice do modelo alimentar do mundo contemporâneo, com o surgimento das grandes indústrias de alimentos multinacionais como detentoras da capacidade de prover segurança alimentar ao mundo.

De acordo com autor, a partir da constatação de que tais etapas não necessariamente corresponderam ao bem-estar da sociedade, e pelo contrário, levaram os países mais pobres a uma extrema insegurança alimentar, os organismos internacionais liderados pela FAO e OMS buscaram novas alternativas 
para a questão da segurança alimentar associando parâmetros de bem-estar nutricional e sustentabilidade social e ambiental no trato da SAN.

No Brasil, o reflexo da adoção de tal modelo internacional e a ausência de solução histórica para a questão da desigualdade e da fome, trouxe para o centro da agenda de governo, a SAN, em uma perspectiva multidimensional, colocando a SAN como uma política estratégica para o desenvolvimento nacional, interligando setores de governo e sociedade na realização do direito dos brasileiros à alimentação adequada.

O conceito adotado no Brasil $^{1}$ expressa diversas dimensões da questão alimentar e traz implicações para o desenho das políticas econômicas e sociais, na medida em que estabelece a inter-relação destas para o alcance da integralidade em SAN. Sua concepção está alicerçada nos princípios do direito humano, da universalidade, da equidade, da participação social, da sustentabilidade, da descentralização e da intersetorialidade (MALUF, 2006).

$\mathrm{O}$ conceito incluiu a garantia do direito ao acesso universal aos alimentos provenientes de produção agrícola sustentável, a fim de favorecer práticas saudáveis e referenciadas culturalmente, como ações organizadas politicamente e nacionalmente por meio de um sistema, com pressupostos de participação social e descentralização e intersetorialidade. Um conceito que abarca a soma de múltiplos elementos na sua concretização.

O Sistema Nacional de Segurança Alimentar e Nutricional (SISAN) instituído por meio da Lei Orgânica de SAN (LOSAN), publicada em 15 de setembro de 2006, é o arcabouço institucional criado para que o poder público com a participação da sociedade civil possa implementar políticas, planos, programas e ações destinados a garantir o direito humano à alimentação adequada. Expressa ainda a competência dos órgãos do sistema na elaboração da política e do plano nacional de SAN.

Várias interpretações orientam o propósito da construção do SISAN. Como sistema nacional ele desafia o Estado e a sociedade a construir uma teia de relações que atuem na direção de alcançar a SAN em todo o território nacional.

Como sistema que se alicerça na participação da sociedade civil e no

\footnotetext{
1 Conceito de SAN - "a realização do direito de todos ao acesso regular e permanente a alimentos de qualidade, em quantidade suficiente, sem comprometer outras necessidades essenciais tendo como base práticas alimentares promotoras de saúde que respeitem a diversidade cultural e que sejam ambientais, cultural, econômica e socialmente sustentáveis" (BRASIL, 2006).
} 
controle social por meio de conselhos e conferências o SISAN se coloca a prova na internalização das demandas sociais e nos mecanismos e estruturas de negociação que abarca. Como sistema público de proteção social não contributivo se diferencia dos demais sistemas da seguridade social por sua lógica intersetorial, conferindo uma estrutura diferenciada e impondo novas estratégias de gestão (BURLANDY2009 e NUNES et AL 2013).Nesse aspecto, se a descentralização e a ênfase na participação social fazem parte de um processo "natural" de consolidação de políticas da esfera social, dado pós 88 , a intersetorialidade precisará ser construída por meio das deliberações que alterem a forma de planejamento, de gestão e do próprio processo de trabalho das instituições (NUNES et AL, 2013).

Maluf e Reis (2013) afirmam que o SISAN deve ser compreendido como um sistema aberto, dada a sua característica de organizar e monitorar políticas de diversos setores de governo e ações de setores não governamentais. Nessa perspectiva, destacam que os limites de atuação do SISAN decorrem da menor autonomia e da maior complexidade das inter-relações quando comparado a sistemas de comando único como SUS e SUAS.

As diversas visões sobre o SISAN apontam para a noção de que sua construção nacional não é tarefa simples. O federalismo brasileiro, no qual os municípios combinam unidade e autonomia, implica para a SAN a organização de arranjos institucionais complexos para o alcance de resultados nacionais.

A trajetória brasileira referente à construção do sistema e da política de SANé considerada diferenciada desde sua origem devida a uma ativa participação da sociedade civil (BURLANDY ET AL, 2009). Ultrapassando desafios entre diferentes governos, a história mostra que o tema da alimentação e nutrição na perspectiva do direito e da cidadania esteve presente no debate de estudiosos e técnicos e em fóruns da sociedade civil como estratégia de superação da fome e das desigualdades sociais. A vitalidade dos movimentos sociais presentes no processo de redemocratização brasileira durante a elaboração da Constituição Federal de 1988 e nas décadas seguintes empurrou a agenda de SAN para o interior da agenda social do Governo produzindo importantes alterações na política pública brasileira.

A essencialidade da descentralização nas políticas sociais trazidas pela CF 1988 é reforçada na lei de criação do SISAN. Muito embora, como argumenta 
Arretche (2005), na maioria das políticas sociais prevaleçam as prerrogativas federais, como financiamento e adequação a padrões nacionais, que acabam por incidir sobre a autonomia dos entes subnacionais, conferindo certa homogeneidade às ações e programas.

Entre as principais mudanças da institucionalidade das políticas assistenciais, no Brasil pós 1988, estão à descentralização de poder e recursos e a ampliação dos mecanismos de participação (DRAIBE, 2002). Políticas mais recentes trazem, como.

Inovação, a ideia de gestão intersetorial, tratando de conferir maior efetividade a uma política quando implantada territorialmente.

A importância da descentralização, enquanto processo que define as atribuições de cada nível de governo na formulação, implementação e controle social, é destacada por Burlandy, Magalhães e Frozi (2013), sem deixarem de alertar que, muitas das questões que envolvem a SAN, não se resolvem no plano municipal, impondo assim ações das esferas estaduais e federal na redução de desigualdades locais e regionais.

Lício (2012) por sua vez, constata que o federalismo brasileiro possibilita arranjos centralizados e descentralizados na gestão da política pública social e estes dependem de processos de negociação política muito mais do que de uma decisão do nível central.

Para o SISAN, cujo foco de construção ocorreu a partir do nível central, o processo de descentralização assume características de induzir o modelo e articular institucionalmente as ações de SAN originadas nos demais níveis de governo. Tais ações realizadas muitas vezes sob a coordenação de outros setores, que respondem a sistemas próprios das políticas as quais gerenciam, demandam do governo federal uma aprimorada capacidade de negociação na busca de integração ao SISAN.

As conexões entre sistemas de políticas públicas necessárias à consecução da SAN conferem ao SISAN uma caraterística de articulação horizontal e vertical permanente muito além das estruturas centrais de escuta social. Demanda uma integração entre conselhos, câmaras e redes da sociedade civil a partir de uma interação dinâmica da participação social.

Ressalta-se que tanto a participação social como a descentralização nas políticas sociais até recentemente incluíam a ideia de participação na gestão e no controle da política pública, mediante a criação de conselhos setoriais nos três 
níveis de governo (CKAGNAZAROFF, 2009). No entanto, a criação ainda em 2014 de um sistema nacional de participação social por meio de Decreto Presidencial n ${ }^{\circ} 8243 / 2014$ buscou consolidar a participação social como mecanismo de governo. Embora controvertida, a proposta defende a participação como processo de cogestão das políticas públicas envolvendo as dimensões intragoverno federal; entre o governo federal e os outros entes da federação; entre os governos e a sociedade civil organizada (BRASIL, 2014). Procura-se ampliar não apenas os mecanismos para efetivação da política, mas também garantir a participação social em diferentes etapas das políticas públicas e dos ciclos de planejamento e orçamento público.

O modelo de participação oriundo da concepção da democracia deliberativa pode nem sempre produzir decisões consensuais, dada à tradição autoritária e concentradora de poder que ainda persiste no Brasil. Se a garantia por si só de espaços de diálogo não produz práticas democráticas, estas precisam ser construídas socialmente, por meio de formação permanente de valores de cidadania, democracia, autonomia.

Assim, a política pública participativa no âmbito da formulação e do controle amplia gradativamente seu escopo na medida em que para ela converge não só a gestão, mas também a produção e reprodução de princípios democráticos de cidadania. Ao mesmo tempo, a fragmentação de interesses e a expansão das demandas ao incidir sobre o Estado, forçam mudanças na estrutura de governo contribuindo para inclusão de espaços mais flexíveis à participação social.

Esta formulação aproxima-se da noção de sistema aberto trazida por Maluf e Reis (2013), ao retratar o SISAN, instigando a capacidade técnica e política da burocracia estatal em conduzir processos e criar mecanismos institucionais que promovam o diálogo permanente com a sociedade e a articulação das políticas setoriais.

Atribuindo ao poder público o dever de respeitar, proteger e promover o direito à alimentação, o SISAN orienta-se pela integração de órgãos e entidades da União, Estados e municípios, pela articulação de programas e pela promoção da intersetorialidade. Com tal dimensão, o resultado da política implicará tanto no alcance da SAN no nível individual e coletivo como também na produção de uma gestão democrática da política pública.

A partir da concepção trazida pela LOSAN indaga-se sobre a formação 
institucional do SISAN e a capacidade de expansão vertical e horizontal da política enfocando as diretrizes de descentralização e de intersetor alidade, mediados pelo princípio da participação social. Assim, a pergunta que se pretende responder é se os mecanismos institucionais que o Estado brasileiro lançou mão para implementar o SISAN são suficientes para expandir um sistema nacional de tamanha abrangência como previsto no conceito de SAN.

\section{Pergunta e Objetivos que orientam a Tese}

Situa-se como objetivo geral desta tese analisar o processo de implementação do SISAN, em sua dimensão institucional com vistas a identificar os limites e as potencialidades dos mecanismos adotados pelo governo central para efetivar a SAN, no período de 2004 a 2014. Demarca-se o ano de 2004 pela realização da II Conferência Nacional de Segurança Alimentar e Nutricional, cujo processo de organização representa a recuperação do tema no cenário social e político do país. Os objetivos específicos procuraram: descrever os antecedentes históricos e trajetória da Política de SAN e SISAN, segundo revisão narrativa e integrativa de literatura; explorar o perfil de descentralização do SISAN a luz dos pressupostos legais que delimitaram o SISAN; analisar o percurso do SISAN mediante os mecanismos institucionais implantados, traçando as escolhas dos marcos legais e as repercussões sobre o processo de implementação e analisar a percepção de atores relevantes acerca da implantação e consolidação do SISAN, nos últimos dez anos.

\section{Aproximações Conceituais e Estrutura da Tese}

A pesquisa adota a concepção conceitual de uma institucionalidade capaz de propiciar diálogo, relação entre instituições, criação de instrumentos de gestão e espaços decisórios participativos que além das iniciativas setoriais demanda ações e programas integrados desde sua concepção (BURLANDY ET AL, 2012; MALUF, 2010; BRONZO E VEIGA, 2010; PINHEIRO, 2009).

Se de um novo espaço de compartilhamento espera-se deliberações que em uma perspectiva participativa e equânime sejam contempladas na política, a função estruturante da intersetorialidade em SAN deve contribuir para a melhoria social como valor inerente dos processos de formulação e implementação das políticas públicas. 
Luna (2011) considera a participação como um fator importante da intersetorialidade. $\mathrm{Na}$ medida em que os setores pressionados por grupos e movimentos sociais de interesse produzem diagnósticos mais amplos e integrais do problema social a serem enfrentados, eles se tornam mais interessados a agir intersetorialmente na busca de soluções efetivas.

Ao pensar na trajetória das instituições relacionadas ao SISAN, depara-se com uma complexa rede de órgãos públicos, gestores e profissionais de diferentes especialidades, organizações da sociedade civil e entidades privadas que influenciam sua conformação.

O contexto histórico no qual emerge a política de SAN, a criação de novas instituições e o envolvimento de outras tantas na sua formulação e implantação, as regras e os dispositivos constitucionais alavancados, o processo federativo e a percepção de atores sociais relevantes são analisado para a compreensão da política de SAN.

O primeiro capitulo explora as teorias de análise de políticas públicas, utilizando-se da condensação das cinco etapas que perfazem o ciclo de políticas, a saber, montagem da agenda, formulação da política, tomada de decisão, implementação e avaliação, e refletindo sobre o papel das ideias, interesses e instituições na configuração do Sistema Nacional de Segurança Alimentar. Apresenta ainda o percurso metodológico aplicado nessa tese fundamentado na revisão integrativa de literatura, na análise documental, na análise de dados quantitativos e na análise das subjetividades apresentadas nas entrevistas com atores relevantes por intermédio do método de análise de conteúdo.

O segundo capítulo apresenta a trajetória da SAN e o desenvolvimento da temática como agenda de governo, recuperando por meio de revisão narrativa de literatura (ROTTER, 2007) uma consulta a documentos oficiais que pautam a inscrição da alimentação como direito social na Constituição Federal e seus desdobramentos como política e sistema nacional de promoção da SAN, que se quer participativo e intersetorial.

O terceiro capitulo procura traçar por meio de uma abordagem quantitativa descritiva, a partir de dados secundários, o perfil da descentralização do SISAN com base nos critérios de adesão e regras de pactuação estabelecidas pelo governo federal. Nesse sentido, explora as informações contidas na Pesquisa de Informações Municipais e Estaduais do IBGE do ano de 2014, tratando-as como 
reflexo da produção institucional da política e do sistema de SAN.

$\mathrm{O}$ quarto capitulo percorre os sentidos e subjetividades conferidos ao SISAN e a seu processo de implementação a luz de seus princípios e diretrizes. Partindo do referencial documental produzido pelas Conferências nacionais de SAN até os pressupostos e regras emanadas das leis e decretos que formalizam o SISAN, busca identificar as ideias que conformaram a política e seu direcionamento recente.

O quinto capitulo apresenta as conclusões do estudo com o intuito de contribuir para o referencial analítico das políticas públicas, traçando potenciais e fragilidades institucionais da SAN diante do Estado brasileiro, seu modelo de federalismo e sua jovem democracia.

O conjunto da tese foi desenvolvido com a expectativa de contribuir para o conhecimento acerca da construção da institucionalidade de uma política social e suas aplicações para a área da segurança alimentar e nutricional. Também se encontram entre as expectativas do estudo, analisar a atuação da sociedade civil e sua relação com o Estado na delimitação e escolha de regras e normas que embasam o SISAN e contribuir com o debate acerca da descentralização de um sistema com caraterísticas intersetoriais, em um Estado democrático e de perfil não homogêneo, como o Estado Brasileiro. Por fim, a partir da produção de casos que tratam da institucionalidade do sistema, participar da construção cientifica que alicerça o campo da SAN. 


\section{Capitulo 1 - Pressupostos Teóricos e Metodológicos}

\subsection{Abordagens Teóricas Sobre Análise de Políticas Publicam}

Historicamente, o Estado brasileiro trata a questão da alimentação e nutrição como eixo das ações de assistência social e combate à pobreza. A evolução da temática para além da esfera assistencial foi impulsionada com o realinhamento das ações do Estado em torno do conceito de segurança alimentar e nutricional. A LOSAN aprovada em 2006 inaugurou uma configuração abrangente para a questão colocando o Estado diante de uma nova institucionalidade. Com a incorporação do direito à alimentação como direito social no âmbito da Constituição Federal, completa-se um ciclo marcado pelas disputas e impasses acerca das dimensões que o tema envolve, na medida em que a alimentação é definitivamente alçada a um direito de cidadania.

A promulgação da $\mathrm{CF}$ provocou mudanças significativas nas políticas sociais brasileiras em pelo menos três direções: no campo institucional, pela descentralização político administrativa; no campo social por maior participação popular nos processos de decisão, formulação e implementação das políticas e pela mudança de patamar entre a relação entre Estado e setor privado lucrativo e entre Estado e organizações não lucrativas (MATTEI, 2012).

Não há uma única definição de políticas públicas, no entanto todas apontam "para o lócus onde embates em torno de interesses, preferências e ideias se desenvolvem, isto é, os governos "(Souza,2006; p.25). A autora concorda com Peter (1998) ao afirmar que mesmo diante dos limites impostos à atuação do Estado, decorrente do fenômeno a globalização, tais limites não inibem a capacidade deste de governar a sociedade, embora o torne mais complexo.

Segundo Lobato (2010) em termos gerais, a política social fornece um bem público, o que remete a noção de direito e dever do Estado em seu provimento. Como políticas de garantia de direitos e formadores da cidadania, estas demandam pela ação do Estado, mesmo que seu lócus de efetivação não se restrinja ao Estado e sim se encontre na interseção entre Estado e sociedade.

O conceito de esfera pública trazido por Habermas, ajuda a explicar a complexidade do Estado contemporâneo, fundado no pressuposto do Estado de direito, ao implementar políticas sociais. Para Habermas, (1992, p. 451). "Esfera 
pública é uma "estrutura intermediária" que faz a mediação entre o Estado e o sistema político e os setores privados do mundo da vida".

A evolução da esfera pública, no âmbito do Estado de direito, com a substituição de um público privado individual por um conjunto de instituições diversificadas como partidos, organizações e associações converte a atuação do Estado, transformando-o em suporte da ordem social. O Estado social para Habermas assegura a participação como direito, impactando sua atuação que passa a buscar a legitimação perante a sociedade civil, agora organizada (HABERMAS, 2003).

Considerando que as políticas sociais podem ser entendidas como Estado em ação, como informam Gobert e Muller (1987), elas representam o modelo de proteção social implementado pelo Estado e não podem ser analisadas a temporalmente e desconectadas da sociedade nas quais existem.

Segundo Schwartzman (2004) a evolução das políticas sociais passa por três estágios. A primeira geração é marcada pelas políticas de extensão de direitos; os de segunda geração têm como foco o melhor uso dos recursos públicos e as de terceira geração, são aquelas voltadas a atender integralmente os problemas sociais. No atual cenário encontram-se presentes as características de integração setorial e de conjugação de esforços, reforçando os componentes de articulação das políticas sociais.

Direcionar o Estado para alcançar o objetivo de promoção do desenvolvimento social implica em modificações na organização governamental. Para Inojosa (1998), a antiga organização administrativa do Estado baseada em parâmetros segmentados e especializados, deixou de produzir resultados efetivos ao planejar e executar as políticas públicas, sendo necessária a introdução de mecanismos de gestão específicos que favoreçam a articulação entre setores do governo e entre níveis administrativos autônomos como forma de alcançar maior efetividade no atendimento das necessidades sociais.

Surel e Muller (2004) consideram que a análise das políticas públicas deve questionar a natureza do Estado e as relações que se estabelecem entre a esfera púbica e a privada, na medida em que se produzem decisões políticas que irão afetar a sociedade em geral.

O Estado capitalista, cuja origem liberal remonta os séculos 18 e 19, a depender do enfoque teórico a partir do impacto das revoluções francesa e 
americana, se apresenta com o propósito de limitar o poder do Estado perante os indivíduos e garantir a liberdade, igualdade e legalidade.

Bobbio (1994), adotando uma perspectiva teórica histórico-crítica, afirma que o Estado moderno reúne o aparato institucional com a finalidade de organizar as relações sociais de poder por intermédio de procedimentos técnicos préestabelecidos para prevenir conflitos e com a finalidade de propiciar o alcance dos bens que a sociedade reconhece como gerais aos indivíduos. O mesmo autor já ressaltava que uma reconstrução teórica marxista do Estado sempre irá correr o risco de ser enviesada ou unilateral, uma vez que este na concepção marxista foi sendo conceituado para além de Marx e Engels.

Jessop e Poulantzas (1985) já afirmavam que o Estado é uma relação social vazada pela complexidade das forças políticas, fatores estruturais e conjunturais interpenetrados a tal ponto que sua unidade funcional é forjada nas tensões estruturais e nos conflitos políticos internos e externos.

Poulantzas (1978) ao examinar o tipo capitalista de Estado defendeu que a separação institucional entre economia e política, requereu uma teoria autônoma da política e esboçou alguns conceitos para descrever a matriz institucional do Estado capitalista: um Estado territorial soberano hierarquicamente organizado, coordenado centralizadamente, baseado no domínio da lei, combinado com a democracia burguesa. Ao assumir tal formato, o Estado vai se dirigir muito mais aos sujeitos políticos como cidadãos do que a classes distintas da sociedade, exigindo do sistema político a construção de um projeto nacional que assegure sua dominação sobre a sociedade.

Ao mostrar sua insuficiência diante das alterações do mundo do trabalho, ocorrida com a revolução industrial, a demanda popular por um Estado que se responsabilize pelo social provoca, junto com o surgimento dos ideais socialistas, a ascensão do Estado de bem-estar social. Questões como jornada e idade de ingresso ao trabalho, educação e saúde fazem parte do conjunto inicial de proteção social do Estado. Segundo Giddens (1996) a proteção social é essencial para o significado da sociedade civilizada. O desenvolvimento do Estado de bem-estar origina-se da percepção de que políticas sociais são necessárias para garantir a vida dos indivíduos que estão fora do mercado de trabalho. Em síntese, para o autor, o Estado de bem-estar, resulta dos movimentos de luta dos trabalhadores por condições dignas de vida. 
Embora não se pretenda aqui fazer um debate acerca das teorias de Estado, na abordagem marxista lato sensu, o Estado é a instituição capaz de produzir normas universalmente vinculantes que se cumprem pela coação ao mesmo tempo em que organiza a ordem social capitalista produzida pelo desenvolvimento das forças produtivas, sendo expressão dos interesses das classes sociais dominantes. Ou seja, o capital define os interesses e o Estado legitima esses interesses.

Para Marx, o Estado capitalista é marcado pela efetivação e perpetuação das ideias burguesas, sendo um aparelho de negociação a favor de tais ideais. Marx e, mais especificamente, Gramsci concebem o Estado como parte da sociedade civil e a sociedade civil como parte do Estado (SIMIONATTO, 2011).

No entanto, é a partir da construção de Gramsci sobre a atuação ampliada do Estado no capitalismo moderno, para fazer frente à complexidade dos problemas de relação de poder, que a visão de Estado como mediador dos interesses do capital e a sociedade civil se consolida teoricamente. A identificação da existência de uma sociedade política e de uma sociedade civil no âmbito do Estado marca a formulação de Gramsci sobre a atuação da sociedade civil como agente de legitimação do Estado.

\begin{abstract}
...Gramsci identifica no interior do Estado a sociedade política, composta pelo conjunto dos mecanismos por meio dos quais a classe dominante detém o monopólio legal da violência e, de outro lado, a sociedade civil, constituída pelo conjunto das organizações responsáveis pela elaboração e divulgação ideológica (escolas, igreja, partidos políticos, meios de comunicação etc.) (FERRETI, 2009, p. 117).
\end{abstract}

No capitalismo contemporâneo, o discurso é de que o poder político advém da sociedade civil, que se organiza formal ou informalmente em classes, grupos de interesse, associações e outros tipos de organização que compartilham projetos ou ideias comuns. O Estado Democrático de Direito, traduz a evolução da concepção liberal de Estado, uma vez que, mediante lutas sociais passa a reconhecer direitos não só individuais, mas também ampliando direitos coletivos e sociais. Assim, tem como tônica a legitimidade de sua atuação alcançada tanto pelo poder legitimo do voto popular como pelo conjunto material de regras e leis que a sociedade constrói.

$\mathrm{O}$ avanço da concepção neoliberal sobre a formação do Estado, tem imposto perdas sobre a proteção social dos países em geral, colocando em risco a 
cidadania social construída no último século sobre a extensão de direitos. Estes movimentos mundiais que incidem sobre o Estado, buscando retirar deste o dever de garantir direitos, afetam as políticas especialmente as da esfera social.

Na acepção de Bauman (1999), a globalização afeta diretamente as políticas de Estado e a vida do cidadão, na medida em que o espaço público torna-se privado e os territórios tornam-se campos de batalhas onde os interesses são disputados com instrumentos próprios e fora dos limites do Estado. Para o autor, o enfraquecimento do Estado, o coloca também na seara de luta para manter seu poder e sua capacidade de intervir em questões vitais para a cidadania. Nas palavras de Bauman (1999):

...a globalização por sua independência de movimento, e irrestrita liberdade para perseguir seus objetivos, das finanças, do comercio e indústria de informações globais depende da fragmentação política e do cenário mundial, o que representa a separação política da economia, mas que uma interfere na outra, resultando na perda da política e afetando o poder social. (BAUMAN, 1999; p.76):

Diante da globalização e das políticas neoliberais emergentes na década 90, que apregoam o Estado mínimo, o Brasil ao promulgar a CF de 1988 se coloca diante do impasse de recuperar sua cidadania e instalar um Estado democrático de direito num mundo que convive com as pressões das corporações globais e a necessidade de se desenvolver economicamente de maneira acelerada para se inserir no mercado mundial.

$\mathrm{Na}$ complexidade do contexto brasileiro que coloca o país no meio do caminho do mundo global, o reforço às políticas de desenvolvimento social de assegurar os direitos constitucionalmente expressos ainda é alvo de pressões internas de parte da sociedade, que as vê como, complementares, eventuais e meramente compensatórias e não como direitos universais que devem ser efetivados

Nessa tese, a referência de Estado adotada não é de um Estado homogêneo e definido, mas de um Estado numa perspectiva do capitalismo contemporâneo, marcado pelo tensionamento da reestruturação econômica, social e política (HARVEY, 2009). Defenderemos a ideia de que no Brasil, especialmente durante o processo de constituição do aparato estatal voltado para o combate à fome e pobreza, caminhou-se em sintonia com a necessidade de instituição de políticas públicas constituídas e implantadas em múltiplos níveis entre os entes federados, dos ministérios até as lideranças da sociedade civil estabelecidas nos municípios. 
Se a definição da política social é um processo que reflete o conflito de interesses e os arranjos de poder das instituições do Estado e da sociedade, no caso brasileiro ela se vê diante da necessidade de alavancar a cidadania e de criar instrumentos de democratização do Estado e mudança de valores culturais no âmbito da sociedade. Em um Estado democrático de direito, as políticas públicas, ao refletir as questões coletivas, requerem a construção de um ambiente participativo que seja capaz de expressar e consolidar políticas de interesse geral.

Frey (2009) destaca que o tipo da política afeta os mecanismos adotados e a o nível de conflito a ser administrado. Políticas distributivas implicam em um baixo nível de conflito que resulta em processos mais fáceis de consenso; a redistributiva direciona-se ao conflito, uma vez que representa um deslocamento de poder ou de recursos de uma camada da sociedade para outra, resultando em processos polarizados; políticas regulatórias dependem da configuração da política podendo se dirigir para grupos específicos ou para a busca de equilíbrio da sociedade, originando arranjos que se modificam ao longo do tempo; e as políticas constitutivas, que representam a essência do sistema política, representando a implantação novas instituições ou novas regras gerais, com discussões internas ao sistema político.

A partir do tipo de política é possível estabelecer mecanismos institucionais que possam apoiar sua implementação e organizar espaços, onde os conflitos inerentes a ela possam ser minimizados. Portanto, um sistema que reúne políticas de várias tipologias deve se preparar para coordenar inúmeros arranjos que irão se derivar das forças sociais e econômicas que integram o campo de poder onde a política encontra- se alojada.

O estudo das políticas sociais e sua análise valem-se de três conceitos fundamentais, facilmente diferenciados na nomenclatura de língua inglesa. O primeiro refere-se à Polity, que diz respeito à dimensão institucional do sistema político, ou seja, à base jurídica e administrativa do Estado; em segundo, a Politics, que trata do processo político e seus conflitos; e finalmente à Policy, que remete ao conteúdo da política, traduzidos na configuração dos programas políticos, aos problemas e ao conteúdo das decisões (Frey, 2000).

Nesse âmbito, a abordagem do ciclo das políticas, entendido como a sequência de fases que passa uma política pública, permite tomar em conta a dinâmica e o aspecto temporal. Teoricamente, o ciclo envolve as fases de 
construção da agenda, formulação da política, implementação e avaliação. Embora se reconheça que estas etapas se sobrepõem e não são nitidamente identificadas na realidade, a separação teórica contribui para os estudos analíticos e para a identificação de momentos de inflexão que podem ocorrer ao longo da trajetória da política pública.

Contextos políticos podem ser alterados ao longo do ciclo da política pública, e atores presentes nas fases iniciais de formulação podem não fazer parte da cena política no momento da implementação. Tais fatores influenciam o curso da políticae deixam marcas no âmbito de sua conformação para além da ideia e dos interesses presentes inicialmente, provocando mudanças no espaço público.

Outro ponto fundamental da análise e que marca o curso da política é a noção de público. Este não é homogêneo e reflete realidades muito diferentes que permeiam as expectativas do conjunto de atores da política, sendo que a intensidade de participação de cada segmento irá afetar a implantação da política pública como um todo (SUREL E MULLER, 2004).

Nesta direção, o pensamento de Hall (1997) acerca de como ideias, interesses e instituições afetam a formação da política pública é importante referência para esta tese, na tentativa de identificar como, no âmbito das políticas de segurança alimentar e nutricional, elas constroem o arcabouço por onde percorre a SAN no país.

No campo das ideias, é especialmente importante considerar a conceituação de Hass (1992) sobre comunidade epistêmica, que atua como uma rede de especialistas em áreas específicas do conhecimento ao quais além das noções de validade e um padrão de raciocínio e de práticas discursivas, estão comprometidos com a produção e aplicação do conhecimento, nos marcos de um projeto político dirigido a problemas específicos e com fundamentos comuns (HAAS, 1992a, p.). Em SAN, a identificação de atores sociais que oferecem um conhecimento especializado sobre o problema inicial e delineia soluções para seu enfrentamento na esfera política pode indicar a influência destes sobre a priorização da agenda e na institucionalidade que a política pública poderá alcançar.

Segundo Kingdom (1995), o primeiro passo em direção a construção de uma agenda social, parte da percepção de problemas que chamam a atenção do governo e da sociedade. $\mathrm{O}$ autor destaca que na medida em que os cenários políticos se alteram, novos fluxos de problemas podem incidir sobre a agenda 
exigindo a participação de novos atores sociais e setores de governo que vão aumentar a complexidade da agenda inicial.

Quatro fatores explicam a difusão de ideias em torno de uma agenda e impactam a política pública, a saber: a orientação do partido do governo, a estrutura do Estado e as relações com a sociedade, a natureza do discurso político e o impacto dos eventos externos. (HALL, 1989)

Em linhas gerais, a orientação do partido do governo explica os arranjos institucionais adotados para governar e decidir. Segundo Evans (1998) a configuração institucional do Estado e as experiências prévias com políticas de mesma natureza interferem no processo de difusão das ideias, determinando se esta seguirá ou não o caminho da formação da política. A natureza do discurso revela a conjunção do discurso de ideias e do discurso de poder, situando-se entre o pensamento e a ação em si, neste caso a política pública empreendida (CHARAUDEAU, 2006). A dinâmica social e política que afeta a vida cotidiana são elementos de constante impacto na adoção de uma política pública que podem levar a avanços ou retrocessos na sua formação.

A agenda política das ações e programas de alimentação e nutrição possui reconhecidamente uma trajetória de avanços e retrocessos durante mais de meio século, a partir da década de 30, culminando em uma plataforma exitosa com ascensão do governo do Partido dos Trabalhadores, em 2003.

A organização institucional resultante deste proposito culmina com a criação de uma pasta ministerial especifica que ao longo dos anos vai se reorganizando até assumir o formato de Ministério de Desenvolvimento Social e Combate à Fome, que se responsabiliza pela implantação da política nacional de segurança alimentar e nutricional. Nesta direção, a agenda da SAN foi marcada pela combinação de ações de combate a fome com a implantação de um programa de transferência de renda para as famílias pobres que até os dias de hoje responde oficialmente pelo sucesso dos resultados da redução da fome no pais.

O Programa Bolsa Família, formalizado com a publicação da Lei Federal 10.836 de 09 de janeiro de 2004, caracterizou-se por ser uma iniciativa de combate à pobreza, que atende por meio da transferência condicionada de renda, famílias com em situação de pobreza e extrema pobreza. De acordo com Battaglia (2009), o Programa Bolsa Família, é o carro chefe das ações de combate à fome, por executar a maior parte do orçamento, destinado a segurança alimentar e 
nutricional.

Se na análise da política pública é necessário conhecer se o sentido da política é explicitado ou não pelos tomadores de decisão, como aponta Surel e Muller (2004) o sentido da política de segurança alimentar e nutricional encontra-se conectado a estratégia de distribuição condicionada de renda como principal medida de redução da fome e da miséria no pais.

\subsection{Implementação e Desafios Analíticos da Política Brasileira de SAN}

A implementação de uma nova política pública, especialmente na área social, representa um ponto de inflexão do Estado na busca de uma melhoria social repercutindo na organização do Estado e na ação dos grupos de atores relacionados à questão que se pretende alcançar. A dinâmica da vida social e política afetará o curso de implementação exigindo a cada momento adaptações e alterações que irão moldar a configuração inicial.

Em sendo uma fase onde tudo acontece na tentativa de alcançar o propósito da política (NAJAN 1995 APUD SOARES, CARVALHO E BARBOSA, 2010), a implementação pode não somente representar a tradução das intenções da política, mas também provocar sua transformação.

São várias as visões atribuídas à etapa de implementação a depender da forma como o processo ocorre, se a partir do nível central de governo ou não, de quem toma decisão acerca dos instrumentos de implementação, se vem de cima (abordagem Top- down) ou se são reconstruídas na base (abordagem Bottom-up). $\mathrm{Na}$ implementação, as interações entre atores e instituições e o papel que eles desempenham são elementos centrais no processo de análise, podendo alterar o resultado da política. Para Lazin (1994) combinar as duas abordagens, resulta tanto em uma análise da política oficial, como considera os ajustes que a política sofre ao longo do processo, devido as negociações e barganhas necessárias para que a mesma seja viabilizada.

Os estudos mais amplos acerca da implementação de políticas públicas originaram-se com Pressman e Wildasky (1984). Para estes, a transformação da política em um programa pressupõe que condições essenciais como legislação, acordos entre os órgãos e entidades envolvidas e fundos de financiamento estejam definidas, marcando a etapa da implementação. O mérito dos autores foi 
demonstrar que, apesar da decisão do nível central, a operacionalização de um programa enfrenta obstáculos no nível local. É um processo em constante evolução e marcado por questionamentos acerca das escolhas iniciais. A imprevisibilidade do processo decorre da multiplicidade de atores agregados durante a implementação bem como da mudança de atores que com o passar do tempo trazem mudanças na percepção e interação da política, exigindo novas e mais negociações (PRESSMAN E WILDASKY, 1984; MAZMANIAN E SABATIER, 1983 APUD LIMA E D’ASCENZI, 2013).

Algumas variáveis respondem pelo sucesso ou não do processo de implementação na visão de autores como Howlet e Ramesh (1995); Van Meter e Van Horn (1996); Mazmanian e Sabatier (1996). Tais autores identificaram quatro tipos de variáveis independentes para os estudos de implementação. O primeiro tipo refere-se a natureza do problema, a existência de uma intervenção capaz de resolver ou minimizar tal problema, a existência de uma teoria causal valida e o tamanho do público a ser atendido. O segundo grupo diz respeito as variáveis normativas, o grau em que o plano desenhado estrutura a implementação e a clareza dos objetivos. O terceiro grupo responde pelas variáveis contextuais, na medida em que o contexto social e político de maior ou menor apoio do governo e da sociedade à implementação e o contexto econômico que pode impor restrições financeiras e orçamentarias a execução. Por fim, os autores destacam a organização administrativa, a qualidade dos recursos humanos e a estrutura institucional existente.

Nesta tese, a análise situa-se entre o processo final da etapa de formulação e início da implementação, uma vez que os marcos legais, as regras emanadas do poder federal e o plano de ação encontram-se elaborados e buscam caminhos para sua efetivação, sendo submetidos ao processo de interação com atores de outras esferas de governo e com alterações de contextos políticos.

A passagem do discurso de combate à fome para a política de segurança alimentar e nutricional representa um passo importante para a investigação feita nesse estudo, dada a legitimidade que tal discurso alcançou na sociedade durante décadas. De um problema especifico com possibilidades de intervenção conhecidas e com teoria causal validada avança-se para um problema de níveis variados de complexidade que demandam múltiplas operações de diferentes graus e cujas causas envolvem um conjunto de teorias. 
A análise da implementação do sistema e da política de SAN pressupõe a identificação de inúmeros fatores distribuídos entre a tipologia citada anteriormente e que serão abordados aqui com o propósito de traçar a trajetória institucional da SAN.

A implementação é aqui entendida como uma continuidade da formulação, a partir de um processo contínuo de interação entre os grupos envolvidos, cujas reações e potencialidades influenciam as decisões da política, segundo propõe Rua (1998). Políticas que precisam conectar diferentes redes e organizações exigindo um alto grau de interatividade e cooperação, tem na etapa de implementação um momento sensível para efetivação de seu e resultado.

A descentralização das políticas sociais, trazida pela CF de 1988, é um dos aspectos sensíveis na análise do processo de implementação e constitui um dos fatores de sucesso ou insucesso de tal processo. Não só pela necessidade de reforço das estruturas locais, mas também pela exigência crescente de maior capacidade do governo federal em articular e coordenar a execução da política.

Autoras como Arretche e Carvalho (1996) e Fleury (1999) reconhecem na descentralização, aspectos positivos para a ampliação da participação popular e aumento da autonomia do poder local diante do governo central, reduzindo práticas clientelistas das quais as políticas sociais eram alvo. No entanto, reconhecem que essa abordagem pode ser paradoxal, pois o reforço do poder local sem o devido apoio ao desenvolvimento das instituições da sociedade civil pode levar a uma centralização local e a própria ineficácia das políticas sociais.

No setor saúde, uma das primeiras políticas sociais que se organizou sob a forma de um sistema nacional, estudos sobre a atuação de conselhos locais na perspectiva de fortalecimento da cidadania, capacidade da sociedade controlar os recursos destinados ao sistema, bem como sobre os processos decisórios das comissões de gestores são bem adiantados. Os estudos concordam com a efetividade da descentralização na superação dos problemas locais, reconhecendo limites na sua implementação, e a consideram uma necessidade política para o alargamento da cidadania (ARRETCHE,1995; COHN, 1994; NORONHA,1994.)

As orientações e diretrizes acerca da descentralização trazem para dentro da análise da política social a questão do federalismo. Segundo D’Ávila e Carvalho (2009), desde 1891, o federalismo brasileiro alterna momentos de centralização e descentralização que se relacionam com períodos de regimes autoritários ou 
modelos democráticos. Críticos a essa visão, afirmam que tal alternância nem sempre representou rupturas completas com os mecanismos institucionais da política, podendo também ser observada pela ótica da complementariedade.

Embora a descentralização seja a espinha dorsal das políticas sociais a partir de 1988, o modelo de Estado adotado fundamenta-se em um centro nacional forte, com capacidade decisória e regulatória sobre as demais esferas de poder. A descentralização exige a construção de capacidade tanto dos níveis subnacionais para gerir localmente a política, como do nível federal no papel de coordenador (VIANA e MACHADO, 2009; ALMEIDA, 2007; ABRUCIO, 2005).

Arretche (2004) chama atenção para o fato de que a CF optou pelo modelo de competências concorrentes para gerir a maior parte das políticas sociais. Com isso, os entes federativos podem implementar ações na área de educação, saúde, assistência social, habitação e saneamento, mas como não são obrigados, podem também não implementar. Tal situação impacta a implementação das políticas sociais, as quais podem resultar em ações descoordenadas, desigualdades na oferta de serviços sociais à população.

A recuperação da capacidade de articular os níveis federativos e exercer a coordenação das políticas sociais vem se dando no âmbito do Estado brasileiro com a elaboração de decretos e portarias mostrando que a formulação das políticas e as regras que as orientam acontecem prioritariamente no âmbito do poder executivo. Também vem sendo sistematizados mecanismos de monitoramento e avaliação com a criação de indicadores de sucesso das políticas que colocam o Estado diante de exigências cada vez maiores da sociedade sobre os resultados que devem alcançar, remetendo não só para o desenho correto das políticas, mas testando sua própria capacidade de coordenar os agentes envolvidos em sua implantação.

No entanto, como afirma Rocha (2013) é bom registrar que a capacidade de coordenação é diferenciada segundo as áreas da política. A coordenação federativa abrange uma série de processos que se propagam no âmbito do Estado, como lembra Abrúcio (2005):

A coordenação federativa refere-se às formas de integração, compartilhamento e decisão, que se expressam: em regras legais que obrigam os atores compartilhar decisões e tarefas; em fóruns e mecanismos políticos de negociação intergovernamental; no funcionamento das instituições representativas, no papel coordenador/indutor do governo 
Embora o SISAN tenha sido aprovado por uma lei federal, exigindo grande negociação entre poder executivo e legislativo, e regulado mediante decreto posterior, com inúmeros mecanismos voltados a articulação, intersetorialidade e participação social, lacunas acerca das responsabilidades dos entes federados e financiamento da política, deixaram em aberto a temporalidade e a capacidade de fazer avançar a SAN em todo o território, como será abordado nos capítulos seguintes.

Segundo Junqueira (2004), ao encaminhar uma solução a sua maneira, cada política social deixa de considerar o cidadão e até mesmo as intenções das demais políticas sobre a vida desse cidadão. Daí a articulação intergovernamental ser uma necessidade para a efetivação das políticas e consequente consecução de direitos sociais, que exige uma visão integrada e uma atuação compartilhada do poder público. Procurando especificar o que caracteriza a relação intergovernamental, Wright (1997) apud Strelec e Costa (2016) faz a seguinte acepção:

A natureza das relações intergovernamentais compreende todas as combinações de interações possíveis na produção de políticas processadas entre o governo nacional e local, estadual e local e inclusive interlocal, e ainda, as relações entre as agências setoriais de governo em diferentes níveis (empresas públicas, fundações) e organizações não governamentais - permite incorporar às formas de cooperação intergovernamental, aquelas que envolvem não apenas atores governamentais, mas também participantes que estejam fora do governo. (WRIGHT, 1997 APUD STRELEC e COSTA, 2016; p.42)

As relações de cooperação horizontal entre órgãos do mesmo nível de governo, as relações de cooperação vertical, que se apresentam por meio de pactos, planos e outros documentos que expressem a intenção conjunta de se relacionar bem como fóruns e comissões que reúnam entidades do governo e da sociedade civil podem ser demonstrações da intersetorialidade, cujo interesse e aprendizado vem ser tornando cada vez mais presente como estratégia de implementação das políticas brasileiras.

Nessa tese, o aspecto relacional da SAN em suas múltiplas direções está englobado no sentido conferido ao termo intersetorialidade e será investigado a partir do aparato institucional que conforma o SISAN e das ideias que permeiam sua construção. 
Embora a intersetorialidade esteja atualmente referida em documentos legais da maioria das políticas sociais como estratégia inovadora de gestão e instrumento para a garantia de direitos, reconhece-se os próprios limites da colaboração dela resultante (FALER, 2015). Entre os limites, encontra-se a defesa que cada setor faz de sua atuação, a legitimidade do setor coordenador sobre os demais, situados na horizontalmente na estrutura de poder e a própria capacidade de atuar intersetorialmente em estruturas internas por demais hierarquizadas.

Ao lado da coordenação, o espaço relacional onde a cooperação ocorre também um elemento constitutivo da intersetorialidade. Para tal, para superar os limites setoriais presentes em uma estrutura governamental competitiva, os programas e políticas devem dispor de canais de comunicação, informação e participação que flexibilizem as relações pessoais e corporativas que se manifestam em processos de troca de práticas institucionais para construção de um projeto conjunto de atuação (INOJOSA, 2001; CISNE, 2005).

Martins (2003) ao abordar a fragmentação das políticas públicas contemporâneas e sua superação, propõe uma agenda de integração que considere aspectos da liderança e coordenação, da estrutura e dos processos, dos mecanismos de incentivos à cooperação e ao diálogo, como facilitador da aprendizagem sobre os valores dos atores envolvidos.

Em sendo compreendida como um espaço de aprendizado, onde cada setor com sua história, seu arcabouço teórico e procedimental é instado ou se dispõe a participar da construção de uma nova perspectiva de atuação do Estado, a intersetorialidade resulta de uma pratica de diálogo, o qual a regra estabelecida, e os mecanismos utilizados para gerir a política pública podem impulsionar, embora não sejam isoladamente responsáveis pelo resultado final.

O aprendizado social é considerado por Hall (1993) um importante vetor de mudanças institucionais, na medida em que técnicos e agentes do Estado podem realizar alterações de três ordens. A primeira e a segunda referem-se aos ajustes e incrementos na política que gerem, e a terceira a que o autor considera paradigmática, alia não só a aprendizado, mas também a mudança de instrumentos, das metas e do próprio sistema de ideias que orienta a política.

A construção da PNSAN e do SISAN pode ser interpretada como este momento de mudança paradigmática na abordagem da questão alimentar pelo Estado brasileiro, não só de metas, mas dos mecanismos adotados para 
enfrentamento do problema. No entanto, tal mudança pode sofrer retrocessos na medida que se contrapõe ao sistema político que sustenta o Estado, devendo ser alvo de constantes correções e adaptações para se colocar como jogador relevante no cenário das relações políticas de Estado.

A lógica da ação intersetorial pressupõe a vontade política das organizações, que podem se mostrar mais ou menos permeável ao processo interativo, requerendo uma mudança de cultura institucional nos setores de governo alcançada com a implantação de um projeto nacional de gestão das políticas sociais. Se a descentralização das políticas sociais provocou de maneira intrínseca uma maior atenção com a gestão articulada e intersetorial das políticas sociais, é possível afirmar que o Estado e sua burocracia precisou se transformar para responder aos desafios de uma nova forma de fazer o social.

O contexto político da formação do SISAN foi de inflexão das políticas sociais, com o advento de um projeto de governo que privilegiou a combinação de esforços da esfera federal para implantação de um modelo de desenvolvimento social a partir de uma forte agenda de participação social. A exemplo do que ocorreu com a política de assistência social, e com forte inspiração no modelo de sistema adotado para a área da saúde, a criação de fóruns de pactuação conselhos de participação e Conferências nacionais tornaram-se os mecanismos elencados para criar condições ao diálogo e orientar a tomada de decisão acerca da política.

Romão (2015) aponta que a CF é sucinta quanto aos aspectos da participação social, embora seja evocada com relação as políticas agrícolas, trabalhistas, educacionais e seguridade social, representando um anseio de mudança naquele contexto político. Desde então, segundo o autor, o Estado se viu obrigado a gerar os mecanismos que viabilizassem a participação institucionalizada.

A emergência de conselhos gestores se consolidou após 88, originando um novo patamar de atuação da sociedade na formulação, gestão e controle das políticas sociais. Como assinala Teixeira (2001):

Participação significa fazer parte, tomar parte, ser parte de um ato ou processo, de uma atividade pública, de ações coletivas. Referir a parte significa pensar o todo, a sociedade, o Estado, a relação das partes entre si, e destas com o todo, e como este não é homogêneo, diferenciam-se os interesses, aspirações, valores e recursos de poder. (TEIXEIRA, 2001; p.27) 
Um dos questionamentos mais frequentes sobre os mecanismos de participação que o Estado adota para organizar dentro da burocracia, as demandas sociais, é o grau com que estes instrumentos podem limitar a autonomia dos movimentos sociais. Romão (2015) chama atenção para a ideia de que sociedade civil apartada da sociedade política é relativamente rara.

No contato com os meios políticos e partidários, os agentes vinculados a organizações da sociedade civil, movimentos sociais, igrejas, sindicatos, etc. necessariamente se colocam em posição de disputa política, de maneira a sustentar seus interesses e valores, que por sua vez clivam também a sociedade política (TATAGIBA, BLINKSTAD,2011; TATAGIBA, SERAFIM E ABERS, 2014; ROMÃO, 2014 APUD ROMÃO 2015, p.42).

No entanto, tal situação não inviabiliza a participação, que aos poucos ganha contornos diferenciados no sistema político. Gohn destaca que a institucionalização dos processos participativos no Brasil, passou por dois momentos.

O primeiro marcado pela implantação de conselhos gestores, que se integraram aos órgãos públicos representando uma inovação no campo da formulação e implantação das políticas públicas. A autora aponta que ao longo do tempo a expectativa inicial sobre os conselhos não pôde ser generalizada, com muitos deles se tornando órgãos burocráticos e com a marcante presença de setores já incluídos socialmente. O segundo momento caracteriza-se não mais pela construção dos canais de participação, mas pela gestão destes. São inúmeras as formas de associativismo que estimulam ações coletivas derivadas de movimentos de políticas públicas, de parcerias ente comunidade e ONGs, ou com o setor público que se reúnem com o propósito de democratizar o Estado e fazer avançar a esfera pública (GOHN, 2011).

Mesmo com o avanço da participação social no âmbito do Estado brasileiro é preciso reconhecer que este processo ainda é contraditório, sendo ao mesmo tempo inovador e criativo, mas podendo ser impactado a todo momento pelas formas de organização que o Estado dispõe para viabiliza-la (ROMÃO2015; GOHN, 2011).

No caso da SAN, a recriação do conselho, em 2003, antecede a política e o sistema e decorre de trajetórias passadas onde a questão da fome e da segurança alimentar e nutricional foram protagonizadas quase que exclusivamente pela 
sociedade civil em seus movimentos de ação da cidadania e fóruns de debate que se institucionalizaram como movimentos da sociedade civil. Assim, o SISAN traz um componente peculiar de participação social, com alto grau de representatividade de seus conselheiros no nível federal. Esta capacidade acumulada no nível central é fundamental para a elaboração da lei, formulação da política e do sistema nacional, como será abordado posteriormente. 


\subsection{O Referencial Neoinstitucional na Análise de Políticas Públicas}

O referencial teórico proposto pela corrente neoinstitucionalista, que em suas diversas abordagens, converge no argumento de que as instituições são cruciais para a análise do fenômeno social, podendo exercer forte influência na determinação do processo decisório e dos resultados políticos, conforme assinalam Hall e Taylor (2003), será aplicado aqui de maneira cautelosa, no sentido de orientar algumas das análises sobre as regras adotadas para a implementação do SISAN.

A adoção da perspectiva neoinstitucional na análise de políticas públicas implica em considerar como premissa que o Estado tem um espaço particular de atuação moldando processos políticos e sociais, uma vez que os próprios tomadores de decisão também disputam visões de mundo que conformam as instituições as quais pertencem.

Na visão de March e Olsen (2008) a atenção crescente sobre o estudo das instituições reflete duas redescobertas do marxismo: o Estado como problema na economia política e a relevância de fatores organizacionais para compreensão da atuação do Estado. Embora presente em diferentes estudos sobre legislação, desenvolvimento do Estado e administração pública, assume cada vez mais destaque no estudo da implementação das políticas públicas.

Considerando que a decisão sobre uma política pública envolve um conjunto de instituições ou arranjos institucionais, a abordagem neoinstitucional pode contribuir para a análise relacionada tanto ao ambiente interno como aos atores sociais envolvidos. O entendimento preliminar é de que as regras e procedimentos pactuados implicarão em uma mudança institucional no interior do Estado que exigirá por sua vez uma adaptação dos atores externos, impactando sua forma de atuação.

A questão relacionada aos grupos sociais é especialmente relevante na análise de implementação a política pública, uma vez que tanto a identificação dos mecanismos e canais desenhados pela política para dar acesso igualitário à participação dos grupos como a identificação de grupos sociais ou de interesses que mais influenciam os rumos da política são elementos analíticos que podem explicar as decisões e as escolhas instrumentais realizadas.

Segundo Immergutt (2007), para a abordagem neoinstitucional existem diversas fontes de interesses individuais e coletivos, e as instituições influenciam 
s u a articulação e manifestação na política. Outros dois aspectos é o entendimento de que a forma como ocorre o processo político de participação afeta o resultado desta participação, e que a democracia procedimental pressupõe que o resultado mais justo é decorrente de regras e normas definidas anteriormente. No caso das políticas da área social, cujo elemento da participação ocupa espaço central no desenho e execução destas políticas, torna-se útil investigar o resultado desta participação e sua transformação ou não em regras e normas que orientam a ação dos atores externos e também das organizações do Estado.

Lima, Machado e Gerassi (2012) destacam que a análise das regras acordadas, das ações empreendidas e dos instrumentos públicos adotados para levar a cabo a política são reveladores da relação de poder entre atores no momento da formulação ou implementação; de como a política pode ser afetada por regras gerais que regulam a relação entre Estado e sociedade; de como a posição do ator no conjunto de instituições pode influenciar a manifestação de sua decisão e ainda de como as instituições podem influenciar o resultado da política. Alguns dos temas presentes nestes estudos percorrem o sistema constitucional legal, a organização política do Estado, as relações entre as esferas de governo, o sistema político partidário, as relações entre poderes, as relações entre Estado e sociedade, a organizações dos atores econômicos e sociais.

As autoras destacam que na abordagem neoinstitucional, a questão temporal é uma dimensão a ser valorizada, "a trajetória histórica, o momento e a sequência dos eventos importam para a definição das políticas" (Lima, Machado e Gerassi, 2012; p.129). Daí a importância que o conceito de dependência da trajetória assume na abordagem neoinstitucionalista de cunho histórico. Segundo Pierson (2004) esta baseia- se na ideia de que escolhas prévias definem determinados caminhos e influenciam as possibilidades futuras de decisão.

Como afirma Lima, Machado e Gerassi (2012):

As escolhas políticas se desdobram, ao longo do tempo, na criação de regras e de estruturas, na mobilização de recursos de diversos tipos e no envolvimento de atores sociais, o que confere institucionalidade a uma dada política, aumentando as chances de sua continuidade e reduzindo as possibilidades de alterações de rumo radicais. (LIMA, MACHADO e GERASSI, 2012; p.129) 
Nesta tese, a trajetória da questão alimentar que desemboca na conceituação de SAN, a influência entre instituições e ideias, as regras traduzidas em leis, decretos e resoluções, o federalismo brasileiro, as relações entre as esferas de governo e entre governo e sociedade, são variáveis que afetam a implementação da política de SAN.

São reconhecidos alguns dos limites que a abordagem neoinstitucionalista traz para análise das políticas públicas, uma vez que suas premissas têm poder explicativo limitado a uma conjuntura política especifica, e por abrir um leque de explicações acerca do comportamento político sem considerar variáveis estruturais, conforme ponta Viana, 2009. Assim, somente alguns referenciais serão abordados nessa tese, na medida em que contribuem para elucidar o percurso do SISAN.

A acepção que as instituições importam, longe de assumir uma visão simplista, e sim a de traduzir a complexidade nelas presente, é uma delas, que ajuda a reconhecer a atuação dos gestores do MDS na condução do SISAN.

O conceito de dependência da trajetória por contribuir na identificação da origem das regras formais que orientam os processos de institucionalização da política. E por fim, a possibilidade de incluir na análise a atuação dos atores e ideias o que confere um aspecto dinâmico a abordagem, na medida que a movimentação deste influenciam as instituições e as regras dela emanadas. De acordo com Ostrom et al (1994) ao propor um modelo para análise do desenvolvimento institucional, alguns fatores condicionam a adesão à ideias ou projetos novos, a saber, os atributos do mundo físico; os atributos da comunidade na qual os atores interagem, além das regras que muitas vezes criam dificuldades para esta adesão.

Assim, algumas perguntas básicas desta tese sobre quais as regras que regem o SISAN, como se dá a organização territorial, diante do federalismo brasileiro, quais são as atribuições e responsabilidades destes entes federados, quais são os arranjos de coordenação, e quais e como funcionam os mecanismos de diálogo com a sociedade foram relevantes para reconhecer a dinâmica da política de SAN.

No campo da sociologia do Estado, a questão dos instrumentos de ação pública desperta grande interesse, embora seja raramente objeto central das análises realizadas. Autores como Sabatier (2000) Salamon (2002) e Hall (1986) destacam que embora apareçam de forma marginal nas análises das políticas públicas, tais instrumentos são potencialmente relevantes na medida em que se observam as 
dimensões políticas que envolvem sua adoção pelos governos. 
Para Howlett (1991) a referência aos instrumentos da política é um termo genérico para englobar uma miríade de dispositivos técnicos do governo para implantar uma política. E sua escolha é sempre uma decisão política que depende das possibilidades do contexto histórico e cultural e das lições aprendidas pelas instituições. Hood (2007) afirma ainda que os instrumentos da política variam de acordo com a natureza do grupo de atores sociais que o governo quer influenciar.

A complexidade do Estado e avanço das teorias sobre governança são inequívocas em registrar a necessidade de ampliar a esfera pública tanto para a participação da sociedade civil como para os agentes econômicos, em um processo que oriente as decisões do Estado. Embora com muitas interpretações, a abordagem de governança centrada no Estado reconhece que mesmo diante dos processos de globalização que provocam seu enfraquecimento, este tem alavancado sua própria capacidade institucional e legal de regulação. Para Pierre e Peters (2000) em qualquer modelo adotado para executar suas funções de governo, o Estado é elemento central para operar as estratégias de coordenação das parcerias e das relações com a sociedade.

Ao abordar o tema da governança, não se assume aqui uma visão de governança que opte pela redução do Estado, e sim de registrar que na literatura das políticas públicas busca-se um reposicionamento do Estado diante da emergência e da diversidade com que o social se apresenta nos dias atuais, voltada a ampliar sua capacidade de gestão política e técnica. Implica adotar uma perspectiva de governança baseada no Estado e sua capacidade de regular os diversos arranjos institucionais necessários a implementação de uma política pública, conforme defende Pierre e Peters (2000) Levi Fur (2011) e Peters (2013).

Este arcabouço que abarca a concepção de Estado, das instituições e dos instrumentos de ação pública pretende sustentar a escolha teórica realizada neste estudo. Ao se voltar para a análise da etapa inicial da implementação o SISAN é preciso perscrutar as regras, atores e organizações cujos pressupostos de descentralização, intersetorialidade e participação estão no cerne da construção da política. Assim, pretende-se discutir como o Estado vem moldando sua ação e como isto afeta seus resultados.

Ao pensar na trajetória das instituições relacionadas ao SISAN, depara-se com uma complexa teia de órgãos públicos, gestores e profissionais de diferentes especialidades, organizações da sociedade civil e entidades privadas que 
influenciam sua conformação. O contexto histórico no qual emerge a política de SAN, a criação de novas instituições e o crescente envolvimento de outras organizações na formulação e implantação, as regras e os diapositivos constitucionais alavancados, a descentralização mediante ao modelo federativo brasileiro e a percepção de atores sociais relevantes são analisados aqui, como material substantivo para a compreensão da política de SAN.

A política de SAN que envolve componentes de acesso aos alimentos, de consumo, de produção e abastecimento, requer um modelo não linear que vá além da oferta de serviços como vem se desenhando nos últimos anos. Mesmo que essa fase da política ainda careça de instrumento institucional que faça superar os desafios da federação e da gestão compartilhada, a institucionalidade da SAN se vê diante de optar pela manutenção de um sistema voltado as políticas distributivas ou de avançar sobre a construção de um arcabouço legal e institucional, que a faça avançar no sentido de criar capacidade regulatória que a coloque no centro de decisões da política alimentar e nutricional brasileira como programa de governo que extrapole as agendas dos partidos.

Com base no referencial neoinstitucional aplicado a análise de políticas públicas é possível construir algumas dimensões institucionais que orientam o estudo do SISAN, quais sejam: a trajetória institucional, as regras, as instituições e os atores bem como as ideias expressas por eles. O Quadro 01 sintetiza as dimensões institucionais da PNSAN/SISAN. 
Quadro 01 - Dimensões Institucionais da PNSAN/SISAN






\begin{tabular}{|c|c|c|}
\hline $\begin{array}{l}\text { POLITICO } \\
\text { INSTITUCIONAL }\end{array}$ & $\begin{array}{l}\text { Contexto político e social } \\
\text { da formulação a partir } \\
\text { dos atores, instituições e } \\
\text { ideias. }\end{array}$ & $\begin{array}{l}\text { Instituições envolvidas: CAISAN/ Grupo de Trabalho composto pelos Ministérios da Agricultura } \\
\text { (CONAB) Desenvolvimento Agrário, Desenvolvimento Social, Educação (FNDE) Fazenda, Saúde, } \\
\text { Meio Ambiente, Secretaria Geral da Presidência da República e CONSEA. } \\
\text { Atores: Pastoral da Criança, Articulação Nacional de Agroecologia, FIAN, FBSAN, ABRASCO, Rede } \\
\text { evangélica de ação social, Rede nacional de mobilização social (COEP), Caritas brasileira, Ação da } \\
\text { Cidadania, Representação de povos indígena, Representante da pastoral negra, Articulação do Semiárido } \\
\text { Brasileiro, Confederação nacional de trabalhadores da agricultura, Associação Brasileira da Indústria de } \\
\text { Alimentos, Federação Nacional de Celíacos, Central Única dos Trabalhadores, Central Geral dos } \\
\text { Trabalhadores do Brasil, Força Sindical, Conselho Federal de Nutricionistas, Especialistas (UNB, } \\
\text { UFPR, UNICAMP, UFCE, INESC). } \\
\text { Ideias: Direito à Alimentação como Acesso, Promoção da Saúde como qualidade, Sustentabilidade } \\
\text { Ambiental com Produção agroecológica, Agricultura Familiar, Condições dignas no campo, Inclusão } \\
\text { das comunidades tradicionais como respeito a diversidade cultural, consumo adequado e saudável, a } \\
\text { partir da valorização de alimento não processados, com respeito aos portadores de necessidades } \\
\text { alimentares especiais. } \\
\text { Estratégias de influência dos atores: defesa de ideias e interesse por meio dos mecanismos de } \\
\text { participação, e atuação direta sobre o governo. Reforço ao componente intersetorial como forma de } \\
\text { disseminar e fortalecer a agenda de SAN. } \\
\text { Arranjos institucionais: CONSEA e CAISAN, Frente Parlamentar de SAN. }\end{array}$ \\
\hline
\end{tabular}




\begin{tabular}{|c|c|c|}
\hline $\begin{array}{l}\text { HISTÓRICO } \\
\text { INSTITUCIONAL }\end{array}$ & $\begin{array}{l}\text { Trajetória Histórica, } \\
\text { Sequência de Eventos } \\
\text { e Rupturas. }\end{array}$ & $\begin{array}{l}\text { Origem do combate á fome: movimentos da cidade religiosos ou não em torno de acesso regular aos } \\
\text { alimentos, movimentos do campo em torno de produção de pequenos agricultores e melhoria das } \\
\text { condições de trabalho no campo, movimentos de reforma agraria, movimentos em prol de processos de } \\
\text { produção mais sustentáveis, circuitos alternativos de abastecimento, estudos acadêmicos acerca da fome e } \\
\text { da desnutrição, condicionantes e indicadores de melhoria. } \\
\text { Primeira versão do Projeto Fome Zero advindo de um governo paralelo liderado pelo Partido dos } \\
\text { Trabalhadores e criação de um mecanismo institucional de participação e de intersetor alidade na } \\
\text { formação do primeiro CONSEA. } \\
\text { Ruptura deste projeto, mas com manutenção do ativismo comunitário. Vitoria eleitoral que coloca o PFZ } \\
\text { como agenda de governo. Reconstituição do CONSEA e implantação de instancias de governo no nível } \\
\text { federal. } \\
\text { Nova Ruptura e liderança das ideias de programas de acesso a renda e alimentos, ênfase na } \\
\text { transferência de renda, alimentação escolar e compras públicas de pequenos agricultores no tripé - PBF, } \\
\text { PNAE e PAA. }\end{array}$ \\
\hline $\begin{array}{l}\text { CONJUNTURAL } \\
\text { INSTITUCIONAL }\end{array}$ & $\begin{array}{c}\text { Fatores } \\
\text { Externos que } \\
\text { condicionam a } \\
\text { implementação }\end{array}$ & $\begin{array}{l}\text { Perda da centralidade da agenda, a favor de escolhas menos conflituosas. Possíveis interesses de atores } \\
\text { ocultos como representantes do agronegócio, ou de forças de governo alinhadas a estes movimentos, que } \\
\text { não são expressas diretamente, mas permeiam os conflitos no campo de SAN. }\end{array}$ \\
\hline
\end{tabular}

Fonte: adaptação da autora de elementos do quadro analítico proposto por Pereira, 2014. 


\subsection{Procedimentos Metodológicos e Instrumentos de Coleta}

\subsubsection{Delineamento da Pesquisa}

De acordo com Minayo (2008) o objeto das ciências sociais é histórico e qualitativo em sua essência, uma vez que os grupos sociais são mutáveis e as instituições, leis e visões de mundo são provisórias e em constante dinamismo. A autora afirma que a pesquisa qualitativa trabalha o universo dos significados, dos motivos, das aspirações, das crenças, dos valores e das atitudes.

O processo de trabalho científico em pesquisa qualitativa divide-se em três etapas: (1) fase exploratória; (2) trabalho de campo; (3) análise e tratamento do material empírico e documental (MINAYO, 2008). A pesquisa quantitativa, por sua vez, enfatiza o raciocínio dedutivo, os princípios da lógica e as características mensuráveis da experiência humana.

Como bem afirma Almeida Filho (2003):

A qualidade é primordial e antecede e subordina a quantidade. A quantidade dela deriva, sendo mera propriedade de facetas dos objetos que aceitam uma atribuição de dimensionalidade. (ALMEIDA FILHO, 2003; p.155)

Ao buscar analisar a historicidade bem como as práticas institucionais que incidem sobre a SAN a pesquisa adotou métodos e técnicas da pesquisa mista. Seguindo Minayo (1993) não há um método melhor que outro, uma vez que o método adequado será sempre aquele que irá responder as perguntas do pesquisador. Na medida em que o método quantitativo responde pela magnitude dos fenômenos, e o método qualitativo conforma sua intensidade, a aplicação da triangulação de métodos e técnicas amplia a forma de obter conhecimentos diferentes, embora complementares (MINAYO \& GOMEZ, 2003).

Neste sentido, o percurso metodológico desta tese adota como referência a triangulação de métodos e técnicas como forma de apresentar a dimensão institucional do SISAN em extensão e intensidade do processo que cerca sua implantação.

\subsubsection{Etapas da Pesquisa}

A tese foi desenvolvida em três etapas, de modo a articular análise 
quantitativa e qualitativa, integrando métodos e técnicas que se mostraram complementares para a análise pretendida.

\subsubsection{Revisão Narrativa e Revisão Integrativa de Literatura}

O método de revisão narrativa burca situar o desenvolvimento da temática por intermédio da consulta a literatura nacional e internacional, percebendo discursos e buscando caracterizar o objeto de estudo em múltiplos enfoques e perspectivas.

Com o objetivo de analisar a construção histórica e nutricional no Brasil no período de 2004 a 2014, por meio do método de revisão integrativa de literatura na temática de segurança alimentar, o estudo buscou a identificação de atores e setores presentes e ausentes na conformação da política analisada a partir do estado da arte da produção científica de pesquisadores nacionais. Pesquisadores internacionais e produções foram integrados na medida em que elucidem aspectos, conceitos, e perspectivas que favoreçam o trabalho epistemológico.

Para explorar a produção acadêmica sobre Segurança Alimentar e Nutricional a revisão de literatura respondeu a seguinte pergunta: "Como são tratados o conceito, a política e o sistema de SAN no escopo da produção acadêmica sobre Segurança Alimentar e Nutricional no período de 2004 a 2014?" foram utilizadas as bases eletrônicas de dados da CAPES, da Literatura LatinoAmericano e do Caribe em Ciências da Saúde (LILACS) da Bireme, da Medical Literature Analysis and Retrieval System Online (MEDLINE) do Pubmed e da Red de Revistas Científicas de América Latina y el Caribe, España y Portugal (Redalyc). Os descritores controlados foram selecionados na Medical Subject Headings (MESH) da National Library of Medicine (NLM) dos Estados Unidos e dos Descritores em Saúde (DECS) da Biblioteca Virtual em Saúde (BVS).

A revisão integrativa é um método que proporciona a síntese de conhecimento e a incorporação da aplicabilidade de resultados de estudos significativos na prática. Justifica-se o método com o entendimento de que a revisão da literatura é uma parte vital do processo de investigação o qual envolve localizar, analisar, sintetizar e interpretar a investigação prévia relacionada à área de estudo de interesse. Para Bento (2012) a revisão da literatura é indispensável para obter uma ideia sobre o Estado atual do conhecimento, suas lacunas e a 
contribuição da investigação para o desenvolvimento do conhecimento.

De acordo com Sampaio e Mancini (2010), uma revisão é uma forma de pesquisa que utiliza, como fonte de dados, a literatura sobre determinado tema. São úteis para integrar as informações de um conjunto de estudos realizados separadamente

sobre determinado assunto bem como identificar temas e tendências do conhecimento que possam orientar investigações futuras. Os autores chamam atenção para o fato de que, grande parte da qualidade da revisão depende da qualidade da fonte primária consultada.

De forma geral, as etapas de uma revisão envolvem a delimitação da pergunta, a identificação de fontes, a seleção dos critérios de busca, aplicação dos critérios para a inclusão dos artigos e justificativa de possíveis exclusões, análise crítica dos artigos, elaboração de um resumo sintetizando os achados e apresentação da conclusão.

O modelo abaixo apresenta os passos do processo de revisão integrativa aplicados neste estudo.

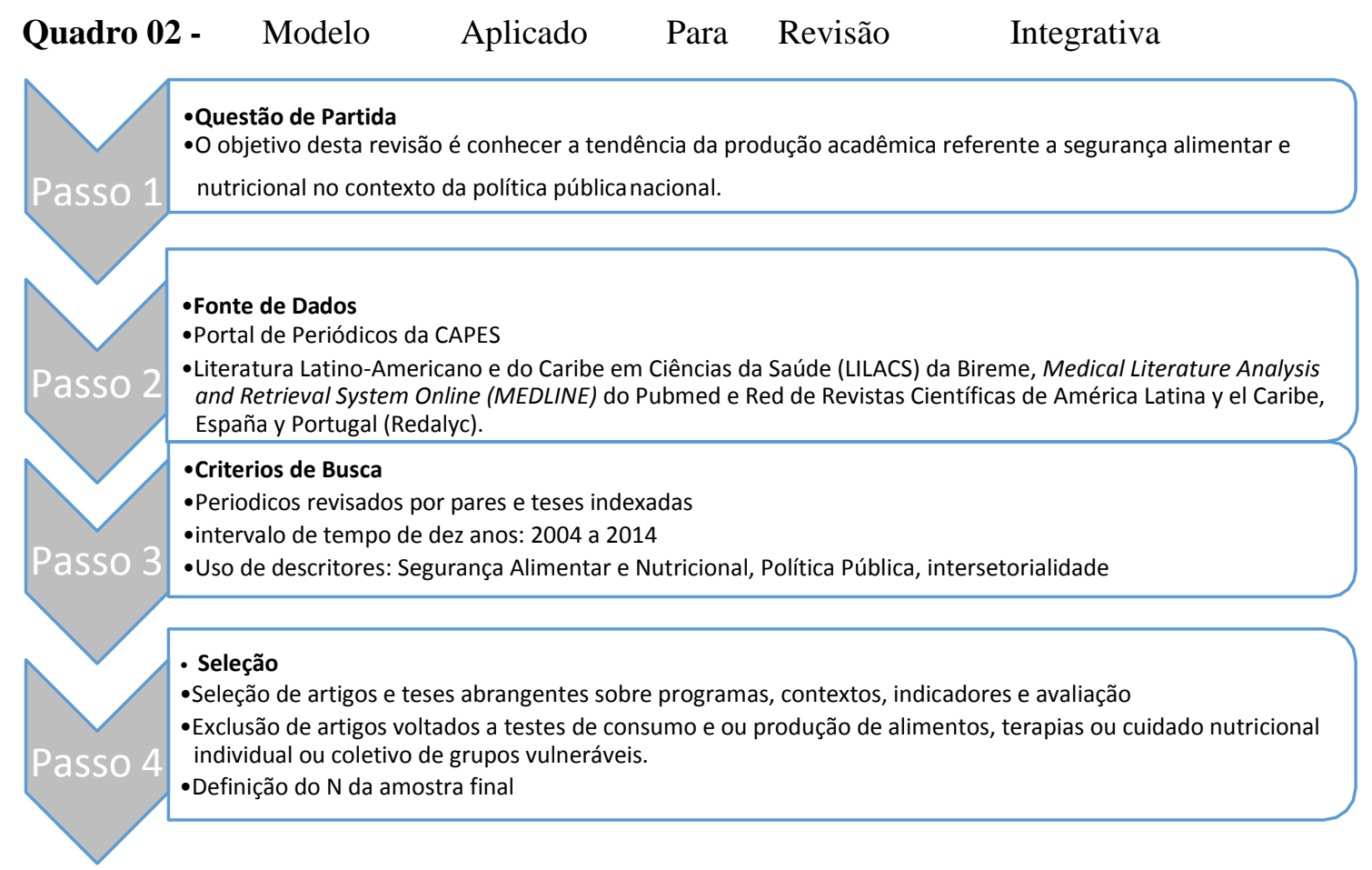

Fonte: Autora.

A partir do descritor "Segurança Alimentar e Nutricional" foram identificados inicialmente 425 publicações revisadas por pares. Ao conjugar os descritores de política pública e intersetorialidade emergem 144 publicações 
englobando teses, dissertações e artigos indexados, sendo que 22 foram excluídas por representaram repetições. Foram selecionados 106 artigos classificados como periódicos revisados por pares e 16 teses e dissertações, as quais foram classificadas pelas temáticas abordadas, como apresenta o Quadro 02.

Quadro 03 - Classificação da Produção Cientifica Nacional Selecionada de acordo com Eixo Temático de SAN, 2004 - 2014.

\begin{tabular}{|c|c|c|c|}
\hline EIXO TEMÁTICO & ARTIGOS & TESES & OBSERVAÇÕES \\
\hline Acesso à alimentação & 16 & 6 & $\begin{array}{l}\text { Inclui Programas de acesso a renda e aos } \\
\text { alimentos }\end{array}$ \\
\hline $\begin{array}{l}\text { Economia, } \\
\text { Desenvolvimento, } \\
\text { Agricultura Familiar, } \\
\text { Ambiente, Produção e } \\
\text { Consumo }\end{array}$ & 15 & 3 & $\begin{array}{l}\text { Inclui Agricultura } \quad \text { Familiar, } \\
\text { Sustentabilidade, Economia } \\
\text { Ambiente }\end{array}$ \\
\hline Direito Humano & 6 & 2 & $\begin{array}{l}\text { Inclui Perspectiva do Direito e Populações } \\
\text { Específicas }\end{array}$ \\
\hline $\begin{array}{l}\text { Saúde }- \text { Nutrição e } \\
\text { Segurança dos Alimentos }\end{array}$ & 30 & 0 & $\begin{array}{l}\text { Inclui indicadores de desnutrição, obesidade } \\
\text { e insegurança alimentar }\end{array}$ \\
\hline Educação e Cultura & 6 & 0 & Inclui Educação Alimentar e Cultura \\
\hline $\begin{array}{l}\text { Política, } \quad \text { Recursos } \\
\text { Participação e Contexto }\end{array}$ & 18 & 5 & $\begin{array}{l}\text { Inclui a organização, estrutura, participação } \\
\text { social, formulação, intersetorialidade e } \\
\text { Cooperação }\end{array}$ \\
\hline $\begin{array}{l}\text { Avaliação, Monitoramento } \\
\text { e Pesquisa }\end{array}$ & 15 & 0 & $\begin{array}{l}\text { Inclui Modelos e Estudos Avaliativos e } \\
\text { Pesquisa em SAN }\end{array}$ \\
\hline Total & 106 & 16 & - \\
\hline
\end{tabular}

Fonte: Autora.

A partir dos resultados, observou-se a predominância de artigos sobre aspectos relacionados à saúde e ao estado nutricional da população. É importante destacar que os inquéritos nutricionais realizados na década de 30 (CASTRO, 1984) delimitaram a desnutrição e a fome no país, e marcam a tradição da pesquisa acadêmica brasileira na área da nutrição e da segurança alimentar e nutricional.

A produção de teses reflete a multiplicidade de áreas do conhecimento envolvidas com a temática de SAN. Estas provêm de diferentes programas de pósgraduação, tais como desenvolvimento econômico, desenvolvimento rural, desenvolvimento sustentável, direito, economia e administração, nutrição, política social, saúde pública, serviço social, transversalidade e interdisciplinaridade do tema e a presença de diferentes abordagens sobre a SAN. Universidades e centros de pesquisa tais como Fiocruz, UFRGS, UnB, USP, UNICAMP, PUC/RJ aparecem em maior frequência.

A ênfase da produção acadêmica sobre SAN, enquanto política pública, e 
referente aos mecanismos de formulação, organização de estruturas, participação social e alocação de recursos, bem como avaliação, monitoramento e pesquisa foi observada, após novo processo de exclusão da duplicidade decorrente da presença das mesmas publicações em outros idiomas, em 29 artigos e 5 teses e dissertações, os quais foram adotados como referenciais para analisar o Estado da arte da SAN.

\subsubsection{A Pesquisa Documental e a Análise de Dados Secundários}

Com o objetivo de descrever a organização do SISAN, na lógica do pacto federativo, adotou-se a análise documental e a análise dos dados da MUNIC/ESTADIC, 2014. Foi realizado um levantamento documental (POUPART, 2008) sobre o corpo teórico e/ou discursivo que consolida as formulações políticas e as diretrizes gerais a serem aplicadas a SAN. Elaborou-se um inventário sobre documentos oficiais, portarias e outros textos legais e jurídicos, uma vez que eles, quando repertoriados e analisados possibilitaram restituir contextos históricos, cenários, condições, processos, diretrizes e normas sobre a (as). Política (s). Pública (s), principalmente, aquelas especificamente destinadas à Segurança Alimentar e Nutricional nos últimos dez anos (2004-2014). Estes documentos foram analisados a partir dos propósitos do SISAN/PNSAN. 
Quadro 04 - Relação de Documentos, Leis, Decretos e Resoluções Analisadas.

1

\begin{tabular}{|c|c|}
\hline $\begin{array}{c}\text { Relatórios Finais e } \\
\text { Declarações das } \\
\text { Conferências }\end{array}$ & $\begin{array}{l}\text { Relatório Final da } 2^{\text {a }} \text {. CNSAN: A construção da política nacional de segurança alimentar e nutricional. Março de } \\
2004 .\end{array}$ \\
\hline Nacionais & $\begin{array}{c}\text { Relatório Final 3 } 3^{\text {a }} \text { CNSAN: Por um Desenvolvimento Sustentável com Soberania e Segurança Alimentar e } \\
\text { Nutricional. Julho de } 2007 .\end{array}$ \\
\hline & Carta Política da 4ª . CNSAN: Declaração pelo Direito a Alimentação Adequada e Saudável. Novembro de 2011. \\
\hline & $\begin{array}{l}\text { Carta Política da } 5^{\text {a }} \text {. CNSAN: Comida de Verdade no Campo e na Cidade: por direitos e soberania alimentar. } \\
\text { Novembro de } 2015 .\end{array}$ \\
\hline $\begin{array}{c}\text { Emenda } \\
\text { Constitucional }\end{array}$ & $\begin{array}{l}\text { Emenda Constitucional nº4, de } 04 \text { de fevereiro de } 2010 . \\
\text { Altera o art. } 6^{\circ} \text { da Constituição Federal, para introduzir a alimentação como direito social. }\end{array}$ \\
\hline Lei & $\begin{array}{l}\text { Lei } n^{\circ} 11.346 \text { de } 15 \text { de setembro de 2006. Cria o Sistema Nacional de Segurança Alimentar e Nutricional - SISAN, } \\
\text { com vistas em assegurar o Direito Humano a Alimentação Adequada e dá outras providencias. }\end{array}$ \\
\hline
\end{tabular}




\begin{tabular}{|c|c|}
\hline Decretos & $\begin{array}{l}\text { Decreto n. 7.272, de } 25 \text { de agosto de 2010. Regulamenta a Lei 11.346, de } 15 \text { de setembro de } 2006 \text { que cria o Sistema } \\
\text { Nacional de Segurança Alimentar e Nutricional - SISAN com vistas a assegurar o direito humano à alimentação } \\
\text { adequada, institui a Política Nacional de Segurança Alimentar e Nutricional, cria parâmetro para a elaboração do Plano } \\
\text { Nacional de Segurança Alimentar e Nutricional e dá outras providências. }\end{array}$ \\
\hline \multirow[t]{2}{*}{ Resoluções } & $\begin{array}{l}\text { - Resolução } \mathbf{n}^{\mathbf{0}} \mathbf{0 4} \text {, de } 30 \text { de dezembro de 2010. Torna público o Regimento Interno da Câmara } \\
\text { Interministerial de Segurança Alimentar e Nutricional - Caisan, aprovado pelo seu Pleno Ministerial conforme } \\
\text { deliberado em reunião ocorrida em } 14 \text { de dezembro de 2010, convocada pelo Aviso-Circular no } 11 / \text { MDS, de } 25 \text { de } \\
\text { novembro de } 2010 .\end{array}$ \\
\hline & $\begin{array}{l}\text { Resolução } \mathrm{n}^{\circ} 05 \text {, de } 30 \text { de dezembro de 2010. Institui Comitê Técnico responsável pela coordenação do } \\
\text { processo de elaboração do Plano Nacional de Segurança Alimentar e Nutricional, em atendimento ao estabelecido } \\
\text { nos art. } 18 \text { e art. } 22 \text { do Decreto } n^{\circ} 7.272 \text {, de } 25 \text { de agosto de } 2010 \text { - CT4. }\end{array}$ \\
\hline
\end{tabular}




\begin{tabular}{|c|c|}
\hline & $\begin{array}{l}\text { Resolução n }{ }^{\circ} 09 \text {, de } 13 \text { de dezembro de 2011**. Dispõe sobre os procedimentos e conteúdo dos termos } \\
\text { para adesão dos Estados, do Distrito Federal e dos Municípios ao Sistema Nacional de Segurança Alimentar e } \\
\text { Nutricional. }\end{array}$ \\
\hline & $\begin{array}{l}\quad \text { Resolução n }{ }^{\circ} \text {, de } 30 \text { de abril de 2012. Institui o I Plano Nacional de Segurança Alimentar e Nutricional - } \\
\text { PlanSAN 2012/2015 }\end{array}$ \\
\hline Plano & Plano Nacional de Segurança Alimentar e Nutricional PLANSAN 2012/2015 \\
\hline
\end{tabular}




\subsubsection{Análise dos Dados Secundários da Pesquisa de Informações Municipais e Estaduais - IBGE/2014}

A análise dos dados secundários baseou-se nas informações do Caderno de Segurança Alimentar e Nutricional da Pesquisa de Informações Municipais e Estaduais

- IBGE/2014. A Pesquisa ESTADIC/MUNIC investigou as 27 unidades federadas e os 5.570 municípios existentes no País, levantando informações e dados relativos à gestão e à estrutura de governo, a partir da coleta de informações sobre nove temas, incluindo a segurança alimentar e nutricional.

As unidades de investigação são a Unidade da Federação para a ESTADIC e o município para a MUNIC, sendo os agentes do governo estadual e da prefeitura, respectivamente, os informantes principais. As informações foram coletadas entre julho de 2014 e março de 2015, tendo o ano de 2014 como referência.

O bloco temático de Segurança Alimentar e Nutricional dispõe de informações sobre a estrutura administrativa e instrumentos normativos existentes para a gestão da política de SAN. Foram investigadas a existência de órgão gestor, sua autonomia, vinculação ou subordinação; a publicação de lei; a formação de conselho e sua tipologia; a instituição de câmara intersetorial; a elaboração de plano local, a existência de orçamento próprio para SAN e as ações desenvolvidas em função da origem dos recursos

Tendo como ponto de partida os requisitos mínimos do Sistema Nacional de Segurança Alimentar e Nutricionais previstos no Decreto $\mathrm{n}^{\circ} 7272$ de 25 de agosto de $2010^{9}$, a saber, a existência de Conselho, Câmara e a elaboração do plano de SAN foram analisadas as condições de adesão ao sistema, observando o comportamento de cada requisito isoladamente e a combinação destes simultaneamente, fato que caracteriza a existência do SISAN.

Investigou-se ainda a característica do setor ao qual a SAN encontra-se vinculado e as ações prioritárias desenvolvidas, segundo a origem dos recursos, federal, estadual e municipal. Ressalta-se, que a pesquisa retrata as ações emanadas pelo gestor federal da política, no caso o Ministério de Desenvolvimento Social e Combate à Fome, não incluindo programas e projetos desenvolvidos pelos demais setores que compõem a agenda política da SAN.

Para verificar a associação entre algumas das variáveis utilizadas na análise, 
foram realizados os testes Qui-Quadrado de Pearson e Exato de Fisher. Ambos os testes se propõem avaliar a associação entre variáveis qualitativa. A diferença é que o teste exato de Fisher é utilizado quando alguns dos pressupostos do Qui-Quadrado amostra suficientemente grande e valores esperados menores do que 5 - não são atendidos, fazendo com que a estatística do teste Qui-Quadrado não seja suficientemente boa.

O teste Qui-Quadrado se baseia na medida de nome homônimo, que contabiliza as diferenças quadráticas dos valores observados e dos esperados de uma tabela de contingência (cruzada). Assim, podemos comparar no teste se as proporções observadas têm ou não diferenças significativas e, desta forma, analisar se as variáveis diferem significativamente quanto a essas proporções (CONOVER, 1999)

O teste exato de Fisher se baseia no cálculo de probabilidade das frequências da tabela. A proposta do teste é possibilitar que a distribuição de probabilidade das frequências de qualquer um destes tipos de tabelas seja substituída pela probabilidade da distribuição das mesmas frequências, considerando uma distribuição de probabilidade para a única frequência de valor livre (independente).

Ambos os testes têm como hipóteses iniciais (para testar a independência):

$$
\left\{\begin{array}{c}
H_{0}: \text { Não existe associação entre as variáveis } \\
H_{1} \text { : Existe associação entre as variáveis }
\end{array}\right.
$$

Avaliou-se o p-valor produzido pela estatística de teste para cada um dos testes realizados. O p-valor é a probabilidade de encontrar uma amostra tão extrema quanto a obtida. Quanto menor for essa probabilidade, mais evidência se tem para rejeitar a hipótese nula $\left(H_{0}\right)$.

A análise realizada deriva de dados secundários públicos e publicizados, cumprindo os princípios do Conselho Nacional de Saúde de Ética em Pesquisa, conforme Resolução 466/2012.

\subsubsection{Entrevistas em Profundidade}

A entrevista semiestruturada levantou informações subjetivas relacionadas às opiniões, atitudes e valores dos informantes-chaves. Trata-se de amostra não aleatória de conveniência com 08 participantes convidados pertencentes a grupos que possuam uma aproximação estreita com o objeto investigado. Gestores diretos do SISAN e da PNSAN no nível federal, gestores de setores envolvidos e ex-presidentes e presidente do CONSEA.

A pesquisa teve como critério de inclusão na amostra: 
- Profissionais e gestores envolvidos na temática de SAN.

Buscou-se cobrir as seguintes categorias de análise temática: institucionalidade, gestão democrática, descentralização, participação social, intersetorialidade por meio da identificação das ideias presentes. Essas categorias temáticas foram contempladas nas perguntas fechadas (estruturadas) e abertas levando o participante a discorrer sobre esses temas de forma mais abrangente possível. As questões abertas permitiram transcender as questões que o pesquisador inicialmente pretendeu abordar.

Por fim, foi realizado um tratamento qualitativo sobre o inventário consolidado nesse estudo, a fim de contrapor, comparar, analisar se tal produção discursiva, de fato, corrobora (ou não) para as definições aplicadas à segurança alimentar e nutricional. No limite, a análise também é pautada pelas subjetividades e sistemas de formação de sentido (GONZALES REY, 2005) produzido pela trajetória da pesquisadora na temática. O método de análise de conteúdo (BARDIN, 2009) foi aplicado no tratamento das entrevistas.

\subsection{Instrumentos para Coleta de Dados}

A pesquisa envolveu a realização de entrevistas individuais com aplicação de um instrumento de coleta de dados contendo questões semiestruturadas (Anexo 1)

Elaborou-se um roteiro semiestruturado de perguntas a fim de possibilitar captar a percepção do entrevistado sobre a estrutura implantada e os processos praticados no âmbito institucional, a interação entre Estado e sociedade e a interação entre a coordenação e setores parceiros da SAN. O instrumento de coleta de dados foi composto pelo roteiro da entrevista e por uma matriz de análise dos dados. Estimouse um tempo de 50 minutos para as entrevistas.

Antes das entrevistas foi apresentado o Termo de Consentimento Livre e Esclarecido. Após concordância em participar da pesquisa e assinatura do termo as entrevistas tiveram início, sendo assegurada a descontinuidade em qualquer momento da coleta de dados, segundo resolução para o sistema CEP/CONEP n. 466/2012. O plano avaliativo aplicado na análise das entrevistas (Anexo 2) possibilitou percorrer a fala dos entrevistados classificando as categorias e sentidos presentes. 


\section{Capítulo 2. Trajetória da Segurança Alimentar e Nutricional no Brasil: uma revisão narrativa de literatura}

\subsection{Antecedentes Históricos da Segurança Alimentar e Nutricional}

No Brasil, a percepção da fome como problema social data dos estudos de Josué de Castro nos anos 30. Como médico e cientista social que primeiro registrou a desigualdade brasileira com relação ao acesso aos alimentos, Castro advogava pela urgente a atuação do Estado na melhoria da condição de vida dos trabalhadores, sendo um dos principais defensores do salário mínimo e da implantação de serviços e programas de alimentação (CASTRO, 1937; CASTRO, 1980; MAGALHÃES, 1997) Desde então, a ênfase sobre a questão social ${ }^{2}$ da alimentação e suas soluções alternase na política pública brasileira, com a implantação de planos, programas e ações destinados a responder as necessidades alimentares e nutricionais da população. De uma agenda inicialmente vinculada a criação de programas de assistência alimentar nos setores da saúde, da educação e abastecimento, a questão foi gradativamente incorporando novas dimensões e complexidades relacionadas ao desenvolvimento nacional (MALUF, 2006; PELIANO, 2010).

Embora o Brasil tenha se antecipado em associar a questão da fome à questão social $^{3}$, dado a influência de Josué de Castro, o processo interno de construção de políticas de alimentação e nutrição não é desvinculado dos debates internacionais realizados por meio da Organização das Nações Unidas para Alimentação e Agricultura (FAO). Com origem no pós-guerra, os debates sobre a redução da fome no mundo passam gradativamente de uma visão estritamente focada na produção de alimentos para incorporar o atendimento das necessidades básicas da população (VALENTE 2002).

Em 1974, com a criação do Comitê de Segurança Alimentar da FAO (CFS) ganha relevância a revisão das políticas voltadas à produção e sua relação com acesso físico econômico aos alimentos. Se inicialmente, a segurança alimentar era percebida como a disponibilidade de alimentos básicos para sustentar a expansão do consumo,

\section{2}

A questão social é um produto histórico problematizado das relações contraditórias entre capital e trabalho, e desta relação surge duas condições: objetivas, subjetivas. A condição objetiva diz que: o modo de produção capitalista, é que gera e aprofunda a pobreza, e depois daí surge a questão social. Já na subjetiva, o capitalista necessita da consciência do trabalhador, para que assim possa impor em seu nome os seus interesses. Tanto é que o termo questão social, nasceu das atribuições feita por críticos do sistema e consequentemente, a burguesia. (Pereira, PAP, 2002). 
dez anos mais tarde a compreensão é a de que a segurança alimentar somente será alcançada quando todas as pessoas em todos os tempos tenham acesso físico e econômico aos alimentos básicos que atendam suas necessidades (FAO, 1974,1983).

O CFS foi reformado no ano de 2009 , com vistas a se tornar uma plataforma internacional voltada para promover a alimentação e nutrição para todos, por meio da convergência de políticas públicas. A proposta relaciona políticas setoriais relevantes e inclui além da participação da sociedade civil, o compartilhamento de práticas adequadas e transparentes para reduzir a insegurança alimentar mundial. A intenção parece ser a de, aos poucos, no ritmo das negociações entre países, potencializar a inserção da segurança alimentar e nutricional no cenário das políticas de desenvolvimento, por meio de ações coordenadas em diferentes níveis para desenvolvimento da agricultura, da nutrição e da promoção de direitos (FAO/CFS, 2009).

Na visão de entidades, como a OXFAM, um sistema de governança global em SAN deve:

Gerar um ambiente internacional favorável à promoção e proteção do direito humano a uma alimentação adequada (DHAA); desenvolver políticas e regulações globais eficazes e coerentes para atacar as causas transfronteiriças da insegurança alimentar; promover a implementação coordenada de políticas públicas internacionais, incluindo seu financiamento, em estreita articulação com as políticas regionais e nacionais (OXFAM, 2009; p.2).

Esse movimento internacional de construção de uma governança global para SAN converge com a dinâmica da política interna brasileira, que durante o período enfocado neste estudo, buscou criar identidade e institucionalidade própria sem deixar de se vincular a aspectos estratégicos da vida social brasileira.

No entendimento de Maluf (2010) conceito de segurança alimentar e nutricional vem se tornando central para as questões de desenvolvimento como já o são os conceitos de sustentabilidade ambiental e equidade social, quando colocados como objetivos de políticas públicas estratégicas. Influenciam assim a ação da sociedade e a tomada de decisão dos países quanto ao rumo das políticas de desenvolvimento, compondo um ciclo de decisões que entrelaça as dimensões locais, regionais e globais da SAN.

Uma série de medidas adotadas pelo governo brasileiro está associada a influência internacional da FAO sobre os pesquisadores nacionais e os quadros da 
burocracia governamental (VASCONCELOS, 2004). Ao mesclar a ação internacional e a atuação do Estado sob a questão alimentar, alguns componentes da trajetória política de SAN no Brasil ficam evidenciados.

Cavalheira (2009) constrói a trajetória da SAN ancorada em quatro referenciais que vale a pena situar aqui, como forma de recuperar contextos importantes. A segurança alimentar e nutricional, da década de 80, fortemente disseminada no contexto internacional da FAO, a soberania alimentar, o direito humano a alimentação, da década de 90, e a alimentação adequada e saudável que surge nos anos 2000. Todas estas referências setoriais e globais, como propõe o autor, se conectam e ainda se fazem presentes quando se aborda a questão alimentar.

No que tange ao direito à alimentação, o documento produzido no âmbito da Organização das Nações Unidas, no ano de 2008, intitulado, "Construir a resiliência: uma estrutura de direitos humanos para a segurança alimentar e nutricional mundial" aponta para um arcabouço institucional que reforçe a adopção de uma estratégia nacional para garantir a segurança alimentar e nutricional de todos, de forma a conter mecanismos institucionais que identifiquem ameaças emergentes bem como avaliação de impacto das novas iniciativas politicas ou legislativas sobre o direito humano à alimetnação adequada. Além das medidas, o documento aponta a necessidade da coordenação governamental sobre a atuação de varios ministerios, o aumento da transparencia e a maior participação social (AG, 2008).

As propostas emandas da ONU mostram a estreita conexão da atuação do governo brasileiro na area da SAN com o conjunto de ideias trasnmitidas internacionalmente sobre contexto e institucionalidade de SAN, adensando o conceito e as refererncias que dele emanam.

As referências que o conceito assume e que em um momento ou outro assumem a cena, em função dos atores que se colocam em posição política mais expressiva, marca todo o percurso histórico da política alimentar brasileira, a qual é por si só consolida o argumento a favor de uma institucionalidade para a questão, que vem na forma da materialização de um sistema de segurança alimentar e nutricional.

Parte dos desafios enfrentados para a definição de políticas abrangentes que abarquem todos os fenômenos que envolvem a questão alimentar é decorrente dos diferentes olhares sobre a questão, resultando em um amplo leque de possíveis soluções para seu enfrentamento, a partir de seu recorte epistemológico. Na literatura de saúde, as condições de alimentação e nutrição aparecem como determinantes sociais 
da saúde tendo a SAN como o DHA associados a melhoria do desenvolvimento social, para agrônomos e ambientalistas na produção sustentável de alimentos e na ajuda alimentar, para o educador na melhoria dos hábitos alimentares, para os economistas, na geração de emprego e renda, e para planejadores, na falta de coordenação administrativa e política. Tal observação ilustra as diferentes abordagens da política da SAN, oferecendo pistas para uma análise de sua configuração. (JOHNSON APUD VALENTE, 2002; NASCIMENTO E ZIONE, 2011).

Esta primeira aproximação epistemológica entre as ideias e interesses, que influenciam o campo estudado, é um dos aspectos vitais para que uma política de segurança alimentar e nutricional prospere em sua trajetória institucional, cujo percurso é repleto de disputas bem mais intensas, como apontadas pelo contexto histórico presentes em sua formulação.

Para Peliano (2010), a segunda metade do século 20 registra alguns dos principais marcos da formação da política de alimentação e nutrição no país. Na década de setenta, o II Programa Nacional de Alimentação e Nutrição - PRONAN coloca como questão central a utilização de produtos básicos e apoio a pequenos produtores pelos programas alimentares por meio de compras institucionais; na década de 80, a inclusão do direito à alimentação escolar na Constituição Federal de 88 e na década de 90, o Mapa da Fome do Instituto de Pesquisa Econômica Aplicada (IPEA), que aponta o número de brasileiros que passam fome; o Movimento da Ação da Cidadania e Combate à Fome do Instituto Brasileiro de Análises Sociais e Econômicas (IBASE) que mobiliza a sociedade civil, e a criação pelo governo federal do primeiro Conselho Nacional de Segurança Alimentar (CONSEA).

Vasconcelos (2005) traz em sua experiência analítica, a visão de três recortes históricos importantes para compreender a trajetória da política de alimentação brasileira: a emergência do setor como política social; implantação de uma tecnocracia que alia alimentação e desenvolvimento econômico; e a luta por democratização na solução das questões sociais. Estes momentos marcam os últimos 20 anos da história com a qual o tema da fome e da alimentação conformou um ideário próprio junto a sociedade brasileira e amadurece como questão a ser enfrentada politicamente.

Os marcos históricos, apontados por Peliano (2010) e Vasconcellos (2005) são indicados também na produção científica de autores como Nascimento (2012); Oliveira (2009) Burlandy (2009) Vasconcelos (2004) corroborando a relevância destes para direcionar a construção de uma política de segurança alimentar e nutricional. 
Com a janela de oportunidades que se abre com a preparação da delegação brasileira para a Conferência Mundial de Alimentação de 1996, deu-se início ao debate sobre a necessidade de se constituir uma política de nutrição suficientemente abrangente para inserir as dimensões do direito humano e da segurança alimentar e nutricional em seu escopo. O final da década de 90 é marcado pela aprovação da Política Nacional de Alimentação e Nutrição (PNAN) do Ministério da Saúde, que passa a incorporar como princípios a SAN e a concretização do direito humano à alimentação (PINHEIRO, 2009; PINHEIRO E CARVALHO, 2010).

A PNAN é referenciada como sendo política articuladora entre os campos da saúde e o da SAN e como precursora da disseminação da noção de direito humano à alimentação associado às ações e serviços de nutrição, por ela, ofertados. Faz parte do marco de construção da agenda de SAN alinhando o setor saúde para o debate que irá culminar com a maior visibilidade da temática no universo das políticas públicas federais.

A tentativa de superar um modelo de fragmentação e migrar para uma concepção mais articulada de política vai ocorrer somente em 2003, com a ascensão do Partido dos Trabalhadores, cuja plataforma eleitoral apresentou como projeto para superação da fome, o modelo de integração proposto pelo Programa Fome Zero, pautada na agenda da segurança alimentar e nutricional e que será apresentado a seguir.

\subsection{Contexto Político para Formação do SISAN}

Em um dos seus primeiros pronunciamentos, o presidente eleito, Lula da Silva, reproduz a fala de Martin Luther King, na cerimônia de entrega do Nobel da Paz em $1964^{3}$ afirmando que:

Defini entre as prioridades de meu governo o programa de segurança alimentar, que leva o nome de Fome Zero. Se ao final de meu mandato, todos os brasileiros tiverem a possibilidade de tomar café da manhã, almoçar e jantar terei cumprido a missão da minha vida (SILVA, 2003, p.1)

\footnotetext{
3 "I have the audacity to believe that peoples everywhere can have three meals a day for their bodies, education and culture of their minds, and dignity, equality, and freedom for their spirits"(Martin Luther King's Acceptance Speech, on the occasion of the award of the Nobel Peace Prize in Oslo, December 10, 1964)
} 
O discurso de combate à fome adotado encontra eco na sociedade brasileira, que já havia se reunido sobre o ideal de combate à fome e a miséria proposto pelo sociólogo Herbert de Souza, o Betinho, na década de 90, como abordado em capítulos anteriores.

O Programa Fome Zero (PFZ) lançado pelo governo federal em 2003 decorre do projeto de mesmo nome concebido pelo Instituto da Cidadania, entidade ligada ao Partido dos Trabalhadores. A partir do diagnóstico que o país ainda não dispunha de uma política de segurança alimentar integrada, o projeto buscava incidir sobre a fome e a insegurança alimentar a partir da melhoria de renda da população articulando políticas estruturais e políticas específicas de diversos setores distribuídas entre as metrópoles, áreas rurais e pequenas e médias cidades (TAKAGI, 2010).

Tomazini e Leite (2016; p.25) afirmam que a concepção do Fome Zero de cunho intervencionista motivou as primeiras críticas ao modelo, que acompanharam toda a trajetória do programa até sua extinção.

O PFZ estava baseado em um conjunto de ideias mais intervencionistas do ponto de vista econômico: investimentos para baratear o preço dos alimentos, intervenção na economia territorial para a dinamização da economia local, fortalecimento dos pequenos produtores, por meio da compra e venda de produtos, entre outros.

Para conferir envergadura ao PFZ, o governo federal recria o Conselho Nacional de Segurança Alimentar e Nutricional que havia sido extinto em 1993, cria o Ministério Extraordinário de Segurança Alimentar e Combate à Fome (MESA) e organiza uma assessoria especial de combate a fome para realizar a mobilização social contra a fome no país (TAKAGI, 2010).

Segundo Salles Pinto (2014), a representação plural da sociedade civil no conselho, oferece pistas da diversidade de setores e atores que reúnem interesses na construção da política de segurança alimentar e nutricional. São eles agricultores familiares; povos e comunidades tradicionais, como indígenas e quilombolas; representantes de instituições religiosas, sindicatos, indústrias de alimentos, pesquisadores e especialistas nos temas de SAN; representantes de associações, de conselhos profissionais e de saúde.

Por parte do governo, o carro chefe do MESA passa a ser o Programa Nacional de Acesso à Alimentação - Cartão Alimentação, cuja lei de criação 
considerava a segurança alimentar e nutricional como a garantia da pessoa humana ao acesso alimentar diário, em quantidade suficiente e com a qualidade necessária (BRASIL, 2003)

Ao mesmo tempo ainda se mantinha em funcionamento o Programa Bolsa Alimentação, regido pelo Ministério da Saúde desde o governo anterior. A falta de articulação dos dois programas e a sobreposição de ações e beneficiários logo mostrou a pouca efetividade dos mesmos em alcançar a segurança alimentar. Somada as críticas ao Cartão Alimentação vindas de segmentos do próprio governo, como aponta Tomazine e Leite (2016), as quais indicavam o custo alto do programa baseado no modelo americano do Food Stamp, quando comparado as experiências de transferência de renda, o excessivo número de beneficiários estimado, e a atuação restrita da sociedade civil no nível local.

O modelo enfrentou divergências entre as correntes defensoras dos modelos de transferência de renda baseada na valorização do capital humano (AMARTYA SEM, 1999) o que gerou a unificação dos programas e a formação do Programa Bolsa Família. Mesmo assim, com todas as críticas recebidas, tais programas representam um marco nas medidas voltadas a segurança alimentar e nutricional.

Com a extinção do MESA e a criação do Ministério de Desenvolvimento Social e Combate à Fome, reforça-se a questão da multidimensionalidade da pobreza na qual a segurança alimentar e nutricional é percebida como um componente da erradicação da pobreza, integrando-se ao arcabouço institucional do novo ministério. Embora com a perda de centralidade política, que passa a ser assumida pela construção do Programa Bolsa Família, que vai compor uma secretaria própria, o Fome Zero se mantém como modelo de gestão no âmbito do MDS, agora ancorado na Secretaria de Segurança Alimentar e Nutricional. Ao conservar os eixos de atuação do Programa Fome Zero, o MDS passa a organizar o arcabouço institucional da segurança alimentar e nutricional no Brasil.

\subsection{Desenho Institucional do SISAN}

O Brasil chega ao século 21 com a aprovação constitucional do direito à alimentação como direito social. A SAN coloca-se em destaque na política de desenvolvimento social sendo instituídos leis e documentos destinados a promover a SAN no território nacional. Princípios como intersetor alidade e descentralização estão contemplados nos documentos oficiais, indicando, desde o início, para um cenário no qual a convergência de políticas e programas seria a essência para a 
promoção do acesso à alimentação adequada no nível individual e coletivo, nacional e local.

A Lei Orgânica de Segurança Alimentar e Nutricional (LOSAN) cria o Sistema Nacional de Segurança Alimentar e Nutricional (SISAN) baseado nos princípios da universalidade, equidade, autonomia e respeito à dignidade das pessoas, participação social, e transparência.

Em 2010, a aprovação da Política Nacional de Segurança Alimentar e Nutricional (PNSAN) reafirma a intenção intersetorial e federativa da SAN situando- a no rol das políticas sociais cujos resultados em menor ou maior grau envolvem a superação de dificuldades inerentes ao modelo de gestão articulada e intersetorial, com consequências institucionais ao processo de implantação.

Silva (2014) mesmo reconhecendo que a institucionalidade da SAN advém de conquistas históricas da sociedade brasileira e da estabilidade monetária alcançada na década de 90, é assertivo ao afirmar que:

A engenharia proposta e estabelecida pelo PFZ forneceu o referencial principal para a institucionalização do tema da SAN na agenda das políticas públicas e deveres de Estado (Silva, 2014, p.5).

Para Maluf (2010) tanto o SISAN como o PNSAN têm características supra setoriais, uma vez que pretendem dispor de instâncias de coordenação e pactuação entre setores com enfoques diversos além de recomendar diretrizes para outras políticas. Em que medida outros setores e políticas incorporam a abordagem da segurança alimentar e nutricional e quais aqueles se posicionam de forma aberta essa incorporação irá depender de aspectos que envolvem os mecanismos de coordenação, a capacidade de cooperação e a existência de identidade entre ideias, valores e práticas institucionais.

Instâncias como as Conferências Nacionais, realizadas a cada quatro anos, com atribuição de indicar prioridades ao governo federal; o Conselho Nacional de Segurança Alimentar e Nutricional - CONSEA, cuja composição por representantes da sociedade civil, governo e setor privado tem a atribuição de propor diretrizes e prioridades para a PNSAN; e a Câmara Interministerial de Segurança Alimentar e Nutricional - CAISAN, cuja responsabilidade é articular programas, elaborar e coordenar a execução da PNSAN, integram a estrutura institucional projetada para que acordos e consensos sejam consolidados e deem materialidade às escolhas realizadas pela política nacional de SAN. 
O Quadro 01 apresenta o arcabouço do SISAN e seus propósitos, de acordo com os dispositivos legais em vigor. 
Quadro 05 - Arcabouço Institucional e Propósitos do Sistema Nacional de Segurança Alimentar e Nutricional

\begin{tabular}{|c|c|c|c|c|}
\hline \multicolumn{2}{|c|}{ ARCABOUÇO INSTITUCIONAL } & \multicolumn{3}{|c|}{ PROPÓSITOS } \\
\hline Instâncias Responsáveis & Atribuições & Objetivos & Princípios & Diretrizes \\
\hline $\begin{array}{c}\text { Ministério do } \\
\text { Desenvolvimento Social e } \\
\text { Combate à Fome }\end{array}$ & $\begin{array}{c}\text { Coordenação } \\
\text { Horizontal e } \\
\text { Vertical }\end{array}$ & $\begin{array}{l}\text { Formular e implementar políticas } \\
\text { e planos de segurança alimentar e } \\
\text { nutricional; } \\
\text { Estimular a integração dos } \\
\text { esforços entre governo e } \\
\text { sociedade civil; } \\
\text { Promover o } \\
\text { acompanhamento, o } \\
\text { monitoramento e a avaliação da } \\
\text { segurança alimentar e nutricional } \\
\text { do país. }\end{array}$ & $\begin{array}{l}\text { Universalidade } \\
\text { Equidade; } \\
\text { Autonomia e } \\
\text { respeito à } \\
\text { dignidade das } \\
\text { pessoas; } \\
\text { Participação } \\
\text { Social; e } \\
\text { Transparência. }\end{array}$ & $\begin{array}{l}\text { Intersetorialidade; Descentralização; } \\
\text { Monitoramento da situação alimentar e } \\
\text { nutricional; } \\
\text { Conjugação de medidas diretas e } \\
\text { imediatas de acesso à alimentação, } \\
\text { com ações que ampliem a capacidade } \\
\text { de subsistência autônoma da } \\
\text { população; } \\
\text { Articulação entre orçamento e gestão; } \\
\text { Estímulo ao desenvolvimento de } \\
\text { pesquisas e à capacitação de recursos }\end{array}$ \\
\hline
\end{tabular}

\begin{tabular}{|c|c|c|}
\hline $\begin{array}{c}\text { Conselho Nacional de Segurança } \\
\text { Alimentar e Nutricional }\end{array}$ & Assessoramento & $\begin{array}{c}\text { Produção de consensos e contribuição para elaboração das } \\
\text { normas }\end{array}$ \\
\hline $\begin{array}{c}\text { Câmara Interministerial de Segurança } \\
\text { Alimentar e Nutricional }\end{array}$ & Articulação & Articulação e Negociação Intergovernamental \\
\hline Conferência Nacional & Proposição & Levantamento de demandas e proposições \\
\hline
\end{tabular}

Fonte: Autora 
Numa sociedade que anseia por participação e construção coletiva de políticas e serviços e cuja eleição presidencial do ano de 2003 colocou em marcha um projeto, que tem na sociedade civil seu alicerce mais simbólico, a construção do SISAN com suas esferas de negociação e compartilhamento de poder, parece ser a tradução institucional mais próxima do êxito com que a questão alimentar se incorpora na estrutura de governo e de Estado.

\subsection{Estado da Arte da Segurança Alimentar e Nutricional no Brasil}

$\mathrm{Na}$ última década, a SAN ressurge na pesquisa acadêmica nacional, impulsionada pela atuação do governo federal ao assumir o tema da erradicação da fome como projeto nacional estratégico.

Fatores como a recriação do CONSEA, a criação de um Ministério Extraordinário de Segurança Alimentar e Combate à Fome e a intensa mobilização social em torno da agenda, motivaram pesquisas e estudos no âmbito da formulação e execução das políticas públicas.

Este capítulo trata dos principais conceitos e visões sobre a política de SAN, desde sua concepção até os limites de sua implantação, buscando sintetizar o Estado- da-arte da área.

Em primeiro lugar, ao retomar o conceito de SAN e seu conteúdo abrangente que a coloca como direito ao acesso aos alimentos com qualidade e quantidade, baseada em práticas de promoção da saúde e de respeito à diversidade cultural, ambientalmente, culturalmente economicamente e socialmente sustentáveis, a partir da argumentação de Foucault (2005), segundo o qual:

[...] a história de um conceito não é, de forma alguma, a de seu refinamento progressivo, de sua racionalidade continuamente crescente, de seu gradiente de abstração, mas a de seus diversos

campos de constituição e de validade, a de suas regras sucessivas de uso, a dos meios teóricos múltiplos em que foi realizada e concluída sua elaboração. (FOUCAULT, 2005. p.6),

engloba interesses diversos que contemplam classes sociais diferentes, que lutam por objetivos múltiplos". Mas é diante de tal amplitude, dos interesses dos atores e a partir da escolha institucional realizada, que uma série de possibilidades de sucesso ou insucesso na elaboração da política, as quais irão sustentar e encaminhar a 
efetivação da SAN pode ser investigada.

A trajetória de SAN, a partir do Programa Fome Zero, ainda como projeto idealizado no âmbito do Instituto de Cidadania, ONG vinculada ao Partido dos Trabalhadores, foi abordada por Maya (2006) em sua tese intitulada "A Implantação da Política de Segurança Alimentar e Nutricional no Brasil: seus limites e desafios".

Ancorada na elaboração do Projeto Fome Zero, a autora relata que a política de segurança alimentar e nutricional, tornou-se prioridade pessoal do então diretor do Instituto da Cidadania e futuro presidente da república, Luís Inácio da Silva. O PFZ foi lançado no ano de 2001, em solenidade ocorrida no Senado Federal, permanecendo na agenda política desde então. A eleição de Lula em 2003 representou a transposição do projeto para o programa nacional que ao combinar ações estruturantes com as ações emergenciais, almejava construir a política de segurança alimentar e nutricional.

A autora, ao descrever as inúmeras mudanças ocorridas na trajetória institucional, destaca a distinção da política de SAN das demais políticas de combate à pobreza em geral e registra que a maior ênfase quantitativa sobre o programa de transferência de renda, como vem acontecendo pode causar retrocessos na concepção original de SAN.

Maya (2012) conclui que a agenda de SAN perdeu espaço na agenda do governo federal, diante da dimensão alcançada pelo programa de transferência de renda, ainda que com limites o país reúna condições para implantar uma política nacional de SAN. Como direito; o apelo social e político das ações emergenciais em detrimento de ações permanentes; a inexistência de estatística continua para medir a insegurança alimentar e o uso de medição da pobreza como substituto; a concorrência entre a noção de combate à pobreza e a SAN com disputas de prioridades e orçamentos; a falta de um desenho claro para a política social; e a crescente setorização e verticalização das políticas públicas, o que dificulta a implantação de um sistema como SISAN.

Na perspectiva do constitucionalismo, o estudo de Rocha (2008) aborda a relação entre programas e políticas de SAN com o direito humano à alimentação. Para o autor, a consonância de uma política de SAN com a constituição e a democracia ocorre na medida em que esta promove o direito à alimentação sendo formulada e implementada de forma participativa. Assim, um dos requisitos dos 
programas e políticas de SAN é a reconstrução de relações simétricas que a partir do reconhecimento reciproco se constitui o centro do direito.

De acordo com a abordagem do direito constitucional, as constituições podem ser consideradas como projetos abertos para o futuro que resultam de trajetórias passadas. Assim, a inclusão do direito humano a alimentação na Constituição Federal em 2010 é o marco legal que expressa o reconhecimento do Estado brasileiro com a trajetória de luta da questão da fome e o compromisso com sua superação.

Pinheiro (2009), em sua aguçada análise sobre a PNSAN, afirma que seu processo histórico estrutural, que abarca desde as primeiras iniciativas do Estado brasileiro para a redução da fome, ainda na década de 30, até a concentração de esforços ocorrida durante o período compreendido entre os anos de 2003 a 2006, produziu a LOSAN, como pacto de consenso, representando um êxito importante para a fase de formulação da política. A autora aponta para a necessidade de que princípios e diretrizes tenham debate aprofundado para construir a viabilidade institucional do SISAN.

O risco que a perspectiva de organização sistêmica traz para a SAN é abordado pela autora, alertando que tal modelo pode se mostrar conservador diante dos desafios de universalizar ações que mudem as condições de acessos aos alimentos para o conjunto da sociedade.

Destacando que não é a mera organização de um sistema de gestão que dará conta da complexidade da SAN, a pesquisadora questiona quais seriam as condições de se concretizar o direito humano a alimentação, se o modelo de desenvolvimento permanecer excludente e as políticas públicas não alcançarem a capacidade de exercer a intersetorialidade.

A composição orçamentária do Ministério do Desenvolvimento Social MDS foi analisada por Cruz (2011) que demonstra que orçamento da área de SAN estruturou-se em 13 ações orçamentárias, distribuídas em três vertentes: Programa de aquisição de alimentos - PAA; apoio a rede de equipamentos públicos e serviços de alimentação e nutrição; acesso à agua para consumo e para a produção. A autora informa ainda que destes recursos, $66 \%$ do orçamento é destinado ao PAA.

O estudo mostra a separação institucional do Programa Bolsa Família da área de SAN embora este esteja originalmente vinculado às estratégias de governo dirigidas ao alcance da SAN no país. No âmbito do SISAN, tal organização pode 
influenciar a tomada de decisões sobre PBF muito além das demandas dos órgãos colegiados da SAN e representando para os níveis subnacionais "quase" um novo setor de composição da SAN, a ser agregado no processo de articulação intersetorial.

Na mesma linha de investigação acerca da alocação orçamentária da SAN, Souza (2013) ao construir um quadro analítico dos recursos do PPA 2012 -2015 mostra a desigualdade de destinação de recursos existentes entre setores governamentais, como um fator que impede parcialmente seu processo de implementação.

Quadro 06 - Orçamento empenhado para cada programa da Segurança Alimentar e Nutricional (SAN) de acordo com o PPA (2012-2015).

\begin{tabular}{|l|l|}
\hline Nome do Programa/Ministério Executor & Orçamento -PPA/2012-2015 (mil R\$) \\
\hline (1) Gestão de políticas para agricultura (MTE e MDA) & $37.533 .544,00$ \\
\hline (2) Agricultura Familiar (MDA) & $124.811,00$ \\
\hline (3) Reforma agrária e ordenamento fundiário (MDA) & $11.258 .524,00$ \\
\hline (4) Segurança Alimentar e Nutricional (MDS) & $17.610 .294,00$ \\
\hline (5) Programa Bolsa Família (MDS) & $90.334 .510,00$ \\
\hline (6) Irrigação (MAPA) & $6.248 .641,00$ \\
\hline $\begin{array}{l}\text { (7) Sustentabilidade da agropecuária, abastecimento e } \\
\text { comercialização (MAPA) }\end{array}$ & $227.679 .752,00$ \\
\hline (8) Fomento à inovação agropecuária (MAPA) & $1.643 .263,00$ \\
\hline Total & $2.679 .191,00$ \\
\hline (10) Accesso à água (MIN) & $14.156 .751,00$ \\
\hline (11) ProgramaNacionalde Alimentação Escolar - & $3.500 .000,00$ \\
\hline (12) Saneamento Básico (Ministério das Cidades) & $32.422 .688,00$ \\
\hline & $543.191 .969,00$ \\
\hline
\end{tabular}


Fonte: Baseado nos dados de Souza ${ }^{5}$

Ao concordar com Souza (2013), acrescentamos ainda que, no nosso entendimento, não é somente a disparidade de recursos que pode ser considerada um fator explicativo das dificuldades enfrentadas pelo SISAN. Situações inerentes ao próprio modelo de sistema proposto, o qual se alicerça em programas de governo pré-existentes, como é o caso do PNAE e do Programa de Alimentação do Trabalhador- PAT, ou mesmo em programas que passaram a vigorar com objetivos voltados para o alcance de SAN, como é o caso do PBF e PAA, mas que, institucionalmente, se encontram de fora do aparato de coordenação direta do SISAN, deixa fluida a obrigação institucional dos entes federativos. Soma-se a estes, a dificuldade de atuar organicamente sobre setores de grandes conflitos econômicos e fundiários, como os do agronegócio e da reforma agraria, e a própria ausência de um mecanismo de financiamento que ofereça materialidade as iniciativas empreendidas a partir da orientação sistêmica.

Ao observar o orçamento da SAN, ponderando as ações do MDA, MDS e PNAE, verifica-se que tais ações somam o valor de $\mathrm{R} \$ 111.569 .615,00$, sendo que $81 \%$ destes são dirigidos ao PBF. Ao considerar o orçamento destinado à SESAN/ MDS, órgão responsável diretamente pela implantação do SISAN, este representa $15,7 \%$ do total. Chama atenção que muitos destes setores não se encontram integralmente nas instancias de negociação do SISAN, e muitos dos programas elencados possuem instancias próprias de deliberação e decisão, que mesmo sendo influenciadas pela agenda de SAN, demostram sua autonomia e sujeição à falta de alinhamento com a política que o orçamento faz questão de abarcar.

Bacarin e Grisi (2016) destacam que a segurança alimentar e nutricional e a agricultura familiar foram fortalecidas com as inúmeras inciativas de articulação que emergem nos anos 2000. Os autores apontam a criação de diversos programas buscando articular as políticas para agricultura familiar e as ações de SAN, e destacam o Programa de Aquisição de Alimentos (PAA), o Programa Um Milhão de Cisternas e a clausula de obrigatoriedade da compra da agricultura família por parte do Programa Nacional de Alimentação Escolar em 2009.

Sobre este ponto, Delgado (2012) chama atenção que juntamente com as

5. O estudo de Souza baseou-se em uma avaliação crítica do Plano Plurianual (PPA 2012-2015) referente as ações da política de SAN concluindo que os avanços da política não foram suficientes para superar as falhas na alocação orçamentária havendo a necessidade de melhorias, especialmente no que concerne à questão orçamentária. 
ações de fortalecimento da agricultura familiar, o governo ampliou sua atuação na reconstrução da "economia do agronegócio" investindo na modernização da agricultura, na intensificação do uso dos agrotóxicos, incrementando por outra via os conflitos pela posse da terra.

Aqui parece residir o principal conflito entre as ideias de promoção da SAN e os interesses do agronegócio brasileiro, no qual o PIB brasileiro se vale para registrar seu crescimento. Vale ressaltar que esses setores correm por fora da estrutura da SAN, e não se integram em suas instancias deliberativas, sendo o parlamento e instancia superiores do executivo seu canal de comunicação e pressão sob o governo.

Gomes Junior (2007) ao defender a SAN como princípio orientador de políticas no marco das necessidades humanas básicas, afirma que a condição de realização do direito humano à alimentação requer outros arranjos que viabilizem o pleno desenvolvimento da pessoa humana e não a simples satisfação de necessidades nutricionais. Concorre para isso, a articulação de políticas que além de cumprirem seus preceitos objetivos, contribuem para a condição de SAN. Trata-se de uma discussão que deve abordar a ontologia do modelo de desenvolvimento do Estado Nação Brasileiro para além da economia.

$\mathrm{O}$ autor contesta a ideia de uma política única de SAN, mas advoga a favor do SISAN mediante a organização em escala de sistemas de segurança alimentar e nutricional, entendendo que estes devem vigorar com logicas semelhantes de princípios e diretrizes a exemplo do nacional, mas adequados às realidades objetivas de regiões e municípios.

Conceber SAN é considerar que a organização de sistemas complexos tal qual proposto na LOSAN requer a conscientização de um marco inicial para fruição do DHA. No entanto, Gomes Júnior (2007, p.333) alerta que não é “por meio de meio de leis e vontade manifesta de governos que se muda o mundo". A condição de segurança alimentar e nutricional requer a integralidade dos direitos básicos, ampliando o sentido do desenvolvimento à escala humana via aprofundamento democrático (MAX NEEF, 2005).

Tal visão corrobora a perspectiva desafiante da organização do SISAN na medida em que acrescenta às condições iniciais de efetivação do direito ao acesso aos alimentos, a abrangência do direito ao desenvolvimento humano para realização plena da vida. 
Nascimento (2012) ao estudar o papel do CONSEA na construção da política de SAN, mediante aplicação da abordagem de análise cognitiva das políticas públicas, destaca a atuação decisiva deste colegiado no desenho e implantação de intervenções estratégicas e sistêmicas em SAN, servindo como ponte entre a sociedade civil e o Estado. A visão comum de um projeto democrático participativo em oposição ao projeto de Estado mínimo e os referenciais setoriais como a fome, a segurança alimentar e nutricional, a soberania alimentar, o direito humano a alimentação e a alimentação saudável são ao mesmo tempo pontos de convergência e de conflito, mas conferem ao conselho o papel de elemento indutor da presença da sociedade civil na produção da política de SAN.

A somatória destes elementos permite ao autor afirmar que existe uma política de segurança alimentar e nutricional no país. E embora ela tenha se constituído recentemente, a partir de uma alta fragmentação das ações, programas e políticas, avança, ao adotar a logica intersetorial, na direção de tornar- se uma política de Estado e não de governo.

Custódio (2011) tendo por base a teoria institucional analisou os arranjos institucionais e a alocação de recursos da política de SAN com objetivo de verificar a efetividade do cumprimento do Direito Humano à Alimentação. Sobre o CONSEA, enquanto arranjo institucional de SAN, a autora conclui pela representatividade real da sociedade civil reconhecendo que a legitimidade e atuação dos conselheiros são fundamentais para a formulação e para o acompanhamento da política. Destaca que algumas demandas significativas do CONSEA foram atendidas pelo governo, situando-se entre elas a LOSAN, e recomendações sobre alterações orçamentárias importantes. A autora considera ter havido, uma rápida evolução de temas tratados pelo CONSEA, passando da própria organização a questões mais amplas de cunho orçamentário e considera positiva a localização do conselho como órgão assessor da Presidência da República, pelo caráter intersetorial da política estudada.

A análise de Custódio (2009) sobre o orçamento de SAN trouxe conclusões interessantes, ao mostrar que este é expressivo, porém concentrado em um único programa, ou seja, mais de $50 \%$ dos recursos destina-se ao Programa Bolsa Família, mostrando a concentração de recursos em um único programa que considera importante, mas não estruturante de SAN.

Burlandy (2009) ao estudar, por meio de revisão bibliográfica e análise 
documental, as estratégias adotadas pelo governo central para promover a intersetorialidade em SAN destaca a complexidade de arranjos existentes neste campo e o desafio de fazer confluir distintos mecanismos, processos e instrumentos institucionais.

Ao tratar a SAN como política supra setorial, a autora identifica a dificuldade de equilibrar autonomia dos subsistemas e sua integração, como é o caso do SUS cujas estruturas próprias respondem a logicas setoriais particulares. Neste sentido, considera o lócus institucional - no caso, a localização do CONSEA como órgão assessor da Presidência da República, o peso político dos espaços de coordenação e o grau de inserção do próprio tema na agenda governamental como fatores facilitadores do processo intersetorial.

Burlandy (2009) reconhece o papel ativador da sociedade civil na institucionalização de SAN, mas enfatiza o sistema presidencialista como sendo o sistema onde as prioridades somente são realizadas quando incorporadas pela presidência e por segmentos do primeiro escalão de governo, como é o caso de SAN. Mesmo assim, a autora conclui sua análise afirmando que a institucionalidade formal da SAN no nível federal não é suficiente para promover a intersetorialidade embora seja necessária na indução do processo. Embora a conjugação de diferentes mecanismos institucionais favoreça a intersetorialidade, a autora afirma que os desafios se referem a articulação com a política econômica e construção de um orçamento pactuado entre os setores, que seja integrado a gestão.

$\mathrm{O}$ entendimento acerca das expectativas e desafios da SAN permite uma melhor compreensão dos caminhos trilhados pelo seu processo de institucionalização delineando contornos e conflitos, grupos e instituições envolvidos e afetados pela política de SAN.

O CONSEA como instancia de participação social da política de SAN é caracterizado pelo trabalho elaborado por Boschi (2007). Para a autora a composição do conselho reflete o caráter abrangente e multissetorial da SAN ao reunir representações de diversos segmentos atuantes na temática. Entre estes, são destacados por segmentos, os seguintes grupos de representação:

Agricultura: representantes das organizações da agricultura familiar; agronegócio, agroecologia, e reforma agrária; Povos e Comunidades Tradicionais: extrativistas, pescadores, povos indígenas, comunidades de terreiro, quilombolas; Área de Saúde e Nutrição: associações e conselhos profissionais e de saúde coletiva, representantes de pessoas com necessidades 
alimentares especiais; Outras Representações: religiosa, sindical, direito humano à alimentação; economia solidária, indústria de alimento.(BOSCHI, 2007; p.4)

Entre os processos participativos, a autora destaca a elaboração da lei 11.346/2006 e a construção do SISAN como deliberações da II Conferência Nacional de Segurança Alimentar e Nutricional, cujos conteúdos foram construídos no âmbito do CONSEA. As propostas feitas ao orçamento da união e a construção de um sistema de indicadores destinados a monitorar a SAN são relevantes contribuições do CONSEA. A autora aponta para a capacidade de influenciar o ciclo de gestão das políticas públicas e a alta representatividade do CONSEA como elementos de atualização da agenda da política do governo. No entanto, como lembram Barbosa, Jaccoud e Beghin (2005):

...o CONSEA ganha ou perde poder a depender dos compromissos políticos assumidos publicamente pelo Executivo tanto no cenário externo, diante da opinião pública mundial e aos olhos de agentes financiadores multilaterais das políticas, como internamente, perante a opinião pública. Seu papel legal é redefinido constantemente pela capacidade de aproveitar a conjuntura no estabelecimento de alianças e ações que potencializem suas posições. Ou seja, seus sentidos dependem da rede de relações que logra aproveitar, sendo que a proximidade com as instituições intelectuais, políticas e sociais são as mais importantes. (BARBOSA, JACCOUD E BEGHIN;2005, p.16):

Essa configuração, que limita a atuação do conselho perante o interesse do executivo, e neste caso, diretamente à presidência da república, pode ser percebida como arranjo institucional perfeito para um governo sensível ou mesmo protagonista da agenda, como foi o caso dos dois primeiros mandatos do governo do PT. No entanto, qualquer desequilíbrio nesta relação de força, coloca em risco a atuação do conselho tendo efeito sobre os conselhos dos demais níveis federativos.

A construção da institucionalidade em SAN é percebida como um desafio para a consolidação da política. No entanto, a importância da atuação da sociedade civil e da articulação dos setores de governo é destacada na sedimentação de políticas de alimentação e nutrição e de SAN (COSTA, 2008; RECINE E VASCONCELLOS, 2011; BURLANDY, 2011).

Recine e Vasconcellos (2011) resgatam o processo participativo presente nas políticas de saúde e de SAN e debatem a aproximação da Política Nacional de Alimentação e Nutrição - PNAN com a proposta da Política Nacional de SAN, 
elencando aspectos necessários ao fortalecimento das relações entre os setores da saúde e da segurança alimentar. Na medida em que o SISAN vem sendo construído, as autoras questionam não só como as duas políticas se coordenam, mas também como os dois sistemas, SUS e SISAN, se articulam em suas prioridades, agendas e processos. Tais perguntas contribuem para o diálogo e a construção intersetorial na medida em que provocam a reflexão sobre a criação de uma estratégia comum de atuação.

Sob este aspecto, não se pode minimizar na trajetória da SAN o envolvimento da aérea da saúde, uma das primeiras políticas sociais a se organizar como sistema nacional, de coordenação única, com componente participativo e federativo e com hierarquias de modelos de atenção, proteção e promoção à saúde. Sob a égide do Ministério da Saúde estiveram autarquias responsáveis pela política de alimentação e nutrição durante os anos 70 e dela emergiram planos nacionais que buscaram a seu tempo numa visão integrada tratar da questão da fome em suas diversas formas de expressão na sociedade brasileira.

Também coube ao MS, a organização da primeira Conferência Nacional de Alimentação do país realizada em 1986, como etapa preparatória da Conferência Nacional de Saúde, que levou a aprovação do SUS, na CF de 88. É importante registrar no âmbito do Conselho Nacional de Saúde que surge a Comissão Intersetorial de Alimentação e Nutrição- CIAN que é uma das primeiras experiências intersetoriais para o setor.

A própria formulação da PNAN, liderada pelo Ministério da Saúde nos anos de 1998 e 1999, em um contexto de participação da sociedade, reuniu forças sociais que já manifestavam a preocupação com a segurança alimentar e o combate à desnutrição no âmbito das políticas de Estado e advogavam pela incorporação da noção de SAN e de direito à alimentação como princípios da política. Naquele momento, no entanto, uma serie de indagações sobre a consistência programática destes novos discursos determinaram uma busca de materialidade no âmbito da política pública, a qual foi marcada inicialmente pela disseminação destes conceitos no âmbito de Estados e municípios (CARVALHO, D. ET AL, 2011)

A mudança da orientação partidária no âmbito do governo federal, ocorrida em 2003, impôs um desgaste na atuação institucional do MS sobre a dimensão alimentar e nutricional, embora não tenha impedido que a PNAN transportasse para o SISAN, importantes mecanismos de organização territorial das ações prestadas no 
nível da atenção básica, e por meio das políticas de promoção da saúde e de vigilância sanitária, em seu aspecto mais regulador, as quais passaram a fazer parte do escopo de atuação da SAN.

A institucionalidade de SAN também é percebida como resultado da interação entre Estado e sociedade necessitando a identificação dos múltiplos significados que a SAN na visão de atores relevantes para consolidar os princípios e diretrizes do SISAN. Segundo Costa (2012), o significado do componente intersetorial em SAN é a estratégia mobilizadora e articuladora do sistema, que opta, pela via educacional, reforçar a criação de capacidades locais e setoriais como mecanismo de consolidação do SISAN. Mesmo que a formação de profissionais, gestores e atores da sociedade civil seja percebida como ferramenta estratégica na implementação de um sistema nacional, fazendo parte de um processo de qualificação da participação social e da atuação de agentes do governo, esta não pode ser tomada a curto prazo como única estratégia de sustentação institucional de SAN.

Burlandy (2011) e Anjos e Burlandy (2010) defendem que a perspectiva do direito humano à alimentação com ampla participação social pode gerar uma nova institucionalidade na política pública. Os autores reconhecem que a manutenção do ganho participativo da política de SAN dependerá da capacidade do Estado em regular e apoiar os espaços de participação e envolver os setores do governo com capacidade decisória. A visão dos autores é otimista quanto às perspectivas institucionais da SAN com ênfase dada ao processo participativo, ao compromisso com a intersetorialidade e com a criação de mecanismos de sustentação à política pública.

Na perspectiva de campo, trazida por Bourdieu (1989), a delimitação do campo traz um componente simbólico e cultural que perpassa as instâncias sociais de legitimação. Tais instâncias, na visão do autor englobam, reconhecidamente, na esfera científica, as universidades e as academias e na esfera do arbitrário, a mídia e eventos públicos que procuram difundir ideias em torno de produções intelectuais, acerca de temas de interesse político, social ou ainda da vida cotidiana. Como aponta Montagner e Montagner (2011) ao analisar o conceito de campo de Bourdieu:

"Um campo traz em si mesmo as condições de sua própria reprodução. Isto inclui os meios de formação de novos integrantes (escolas, grupos formais, academias, 
universidades); inclui as instâncias de consagração, responsáveis pela regulação do que é legitimo e o que é desvalorizado, ou seja, os ritos de instituição balizados e consagrados pelas instituições e dispositivos do campo, como as premiações, o auxílio e o fomento à pesquisa, os financiamentos de novos projetos etc.; inclui as instâncias e os modos de seleção dos novos integrantes ou postulantes a tal, como os concursos, os sistemas e as regras de avaliação dos lugares disponíveis aos agentes."(MONTAGNER E MONTAGNER, 2011, P.261)

A partir desta concepção, identifica-se que na formação do campo da política pública de SAN se sobressai, como valor intrínseco, a ampliação da esfera democrática, participativa e intersetorial, refletindo um posicionamento político diante da realidade social. Ressalva seja feita, que neste espaço social, onde atores interagem dentro de determinados princípios e normas, muito longe de significar consenso, as influências externas e internas são prontamente absorvidas, implicando em transformações ao próprio campo.

Assim, o campo de SAN é dinâmico e permeado por construções sociais que emergem do cotidiano da vida social, na medida em que se encontra aberto às mudanças que incidem sobre a sociedade, na sua compreensão sobre a atuação da dimensão institucional do Estado.

Demo (2002), ao construir seu conceito de politicidade, o situa como um processo contínuo de confronto e superação nas relações da sociedade com o Estado a partir da habilidade humana de pensar e intervir em direção ao alcance crescente de autonomia seja individual ou coletiva. $\mathrm{O}$ autor, o coloca como um processo de conquista interminável e o iguala ao processo de participação, o qual necessita de ser continua e permanentemente apropriado pela sociedade.

Entende-se que o SISAN é um modelo estratégico de sistema participativo e intersetorial, a ser completado em sua institucionalidade. Assim a abrangência com que a SAN irá se alojar na esfera governamental dependerá, da capacidade politica e da atuação consciente e informada dos atores sociais que conformam o seu campo.

É interessante recuperar a noção de "comunidade epistêmica" (HAAS, 1992), para interpretar a produção científica em SAN. Sendo tal produção é marcada pela disseminação de uma informação especializada pautada pelo domínio cientifico, a comunidade acadêmica se reforça como ator social relevante que constrói e influencia a agenda da SAN.

Ao descortinar a produção acadêmica brasileira sobre a SAN, enquanto 
política e sistema nacional, algumas lacunas tornam-se evidentes. Pesquisas voltadas a avaliação da política de segurança alimentar e nutricional e do sistema nacional que a transmite, são peças fundamentais para o processo de desenvolvimento social. Pesquisas avaliativas cujo enfoque seja o mérito e o valor de determinada política para a sociedade são relativamente pouco frequentes no país e oferecem uma lacuna a ser preenchida pela pesquisa social aplicada. No caso de SAN, não é diferente.

Embora o tema tenha ensejado diversos olhares da perspectiva acadêmica acerca do conceito, da situação de saúde e nutrição brasileira, do contexto histórico, das interfaces do sistema e dos indicadores de insegurança alimentar, estudos sobre processos e resultados diretos da política de SAN são relativamente raros e representam uma linha de pesquisa promissora, especialmente em programas de pós-graduação, cujo perfil interdisciplinar, comporta diferentes abordagens para o tema. 


\section{Capitulo 3 - Um Panorama da Descentralização do SISAN}

Cumprindo os preceitos da LOSAN, o alcance da SAN implica na convergência de políticas e programas de vários setores com capacidades para promover, na dimensão individual e coletiva, o acesso à alimentação adequada, requerendo um amplo processo de descentralização, territorialização e gestão social.

A descentralização das ações e a articulação entre as esferas de governo figura como uma das diretrizes que orienta a implantação do SISAN tendo na participação social em todas as etapas da política e em todas as esferas de governo, um dos princípios fundamentais de sua construção.

A descentralização representa a um só tempo a transferência de poder do nível nacional para os demais níveis federativos e para as políticas públicas implica em um processo de reorganização do Estado. Exige, portanto, a criação de arranjos institucionais e mecanismos de indução que ofereçam ao território as condições de exercer atribuições a ele delegadas e responder as demandas locais (SILVA, 2000).

Em um Estado federativo, observar a atuação do governo central na formulação e implementação de políticas e a consequente resposta dos demais entes federados faz parte do processo de analisar a influência das instituições sobre a política pública (THERET, 2003).

A complexidade do federalismo brasileiro tem forte impacto sobre a implantação das políticas públicas nacionais. A autonomia dos municípios torna peculiar a dinâmica das políticas, tanto pela necessidade de superação dos obstáculos inerentes ao desenho institucional de cada ente federado, pela necessidade de articular a multiplicidade de arranjos institucionais existentes, como pela necessidade de estruturas de governança local requerida pela descentralização. No entanto, as estratégias de indução empregadas pelo governo federal para estimular a implantação de uma política podem auxiliar a dirimir os obstáculos decorrentes das questões constitucionais (ABRUCIO e FRANZESE, 2007; ARRETCHE; 2004).

Embora existam expressivas variações no processo de descentralização das políticas públicas da área social, enquanto política de configuração nacional e multissetorial, a SAN encontra-se no rol das políticas públicas cujos resultados em menor ou maior grau dependem da superação de dificuldades inerentes ao modelo de federalismo e ao modelo de gestão articulada. Ambos com consequências institucionais ao processo de implantação. 
A abrangência do SISAN, reunindo múltiplos eixos temáticos como, assistência social, abastecimento e consumo de alimentos, ambiente, cultura, direitos humanos, produção de alimentos de base agroecológica, estrutura agrária e saúde, coloca para os agentes públicos federais alojados setorialmente um imenso desafio na transposição do sentido da SAN para os demais níveis de governo. Tal abrangência traz para o cerne do sistema os conflitos inerentes a cada setor, exigindo da sociedade civil e do Estado capacidade técnica e institucional para impulsionar a política, superando entraves internos e externos ao SISAN.

Questões inerentes à coordenação e articulação entre diferentes setores respondem a integração ou não do processo decisório e ao modo como os interesses atuam institucionalmente. A aposta no processo intersetorial, que visa a pactuação de um projeto integrado de intervenção, tem na descentralização um importante desafio para o futuro do SISAN (BURLANDY, 2009)

A partir das perguntas "O SISAN existe como sistema descentralizado? "Onde ele se mostra mais ou menos descentralizado"? "Em que bases o SISAN se organiza?" "Quais as estruturas que reproduz? " Buscou-se analisar os dados da Pesquisa de Informações Básicas do IBGE de 2014 - ESTADIC E MUNIC/2014 ${ }^{8}$ O presente artigo objetivou analisar a configuração do Sistema Nacional de Segurança Alimentar e Nutricional- SISAN a partir da diretriz de descentralização das ações, identificando o ambiente institucional da segurança alimentar e nutricional no país.

\subsection{Panorama Estadual de Implantação do SISAN}

De acordo com as informações coletadas todas as Unidades da Federação possuíam estrutura para tratar da política de SAN. Estas estruturas funcionavam como secretaria em conjunto com outras políticas dos Estados (55\%) e com setor subordinado a outra secretaria (44\%). Somente Minas Gerais informa a existência de uma estrutura própria de coordenação da política de SAN, ligada ao poder central (Tabela 1). 
Tabela 01. Estrutura de SAN no nível estadual segundo vinculação.

Brasil e região. ESTADIC, 2014.

\begin{tabular}{|c|c|c|c|c|c|c|c|c|}
\hline \multirow{3}{*}{ Região } & \multicolumn{8}{|c|}{ Estrutura de SAN por vinculação } \\
\hline & \multicolumn{2}{|c|}{ Secretaria conjunta } & \multicolumn{2}{|c|}{$\begin{array}{c}\text { Setor subordinado } \\
\text { a uma Secretaria }\end{array}$} & \multicolumn{2}{|c|}{$\begin{array}{c}\text { Setor subordinado } \\
\text { ao Poder Executivo }\end{array}$} & \multicolumn{2}{|c|}{ Total } \\
\hline & Frequência & $\begin{array}{l}\% \text { por } \\
\text { Região }\end{array}$ & Frequência & $\begin{array}{l}\% \text { por } \\
\text { Região }\end{array}$ & Frequência & $\begin{array}{l}\% \text { por } \\
\text { Região }\end{array}$ & Frequência & $\begin{array}{l}\% \text { por } \\
\text { Região }\end{array}$ \\
\hline Norte & 4 & 26,67 & 3 & 27,27 & 0 & - & 7 & 25,93 \\
\hline Nordeste & 3 & 20,00 & 6 & 54,55 & 0 & - & 9 & 33,33 \\
\hline Sudeste & 2 & 13,33 & 1 & 9,09 & 1 & 100,00 & 4 & 14,81 \\
\hline Sul & 3 & 20,00 & 0 & - & 0 & - & 3 & 11,11 \\
\hline Centro - Oeste & 3 & 20,00 & 1 & 9,09 & 0 & - & 4 & 14,81 \\
\hline Brasil & 15 & 100,00 & 11 & 100,00 & 1 & 100,00 & 27 & 100,00 \\
\hline
\end{tabular}

Fonte: Autora

No âmbito da gestão estadual destaca-se que em $77 \%$ dos estados, a área de segurança alimentar e nutricional aparece vinculada em primeiro lugar à assistência social, seguida do setor de agricultura, com $11 \%$. É importante registrar que muitas das secretarias de assistência social encontram-se associadas também às áreas de direitos humanos, de agricultura familiar ou de saúde, compondo assim uma variedade de estruturas diversas que respondem pela SAN (Tabela 2) 
Tabela 2. Número de estados com órgão gestor de SAN, segundo a secretaria /setor a qual está associada por regiões e Brasil - 2014

\begin{tabular}{l|l|l|l|l|l|l}
\hline \multicolumn{1}{|c|}{ Órgão Gestor } & \multicolumn{5}{|c|}{ Região } & Brasil \\
\hline $\begin{array}{l}\text { Secretaria /Setor } \\
\text { associada }\end{array}$ & $\begin{array}{l}\text { Norte } \\
(\mathrm{n}=7)\end{array}$ & $\begin{array}{l}\text { Nordeste } \\
(\mathrm{n}=9)\end{array}$ & $\begin{array}{l}\text { Sudeste } \\
(\mathrm{n}=4)\end{array}$ & $\begin{array}{l}\text { Sul } \\
(\mathrm{n}=3)\end{array}$ & $\begin{array}{l}\text { Centro O. } \\
(\mathrm{n}=4)\end{array}$ & $\begin{array}{l}\text { Total } \\
(\mathrm{n}=27)\end{array}$ \\
\hline Assistência Social* & $6(85,71)$ & $8(88,89)^{*}$ & $3(75,00)$ & $2(66,67)$ & $2(50,00)$ & $21(77,7)$ \\
\hline Agricultura & $1(14,29)$ & $0(0,00)$ & $0(0,00)$ & $0(0,00)$ & $2(50,00)$ & $3 \quad(11,2)$ \\
\hline Saúde & $0(0,00)$ & $0(0,00)$ & $0(0,00$ & $0(0,00)$ & $0(0,00)$ & $0 \quad(0,00)$ \\
\hline Direitos Humanos & $0(0,00)$ & $0(0,00)$ & $0(0,00$ & $0(0,00)$ & $0(0,00)$ & \\
\hline Outros & $0(0,00)$ & $1(11,1)$ & $1(25,00)$ & $1(33,33)$ & $0(0,00$ & $3(11,1)$ \\
\hline
\end{tabular}

* Setor de Assistência Social Eventualmente Associado a Outros Setores.

Fonte: Autora

Em princípio, tal situação parece representar a leitura que cada ente federado faz da segurança alimentar e nutricional. Ao fazer a escolha por um ou outro setor de vinculação da SAN pode estar associada ao período e historicidade política com que determinados serviços ou setores se organizaram no Estado. Este aspecto em particular parece explicar a existência do percentual expressivo de estruturas de SAN associados à assistência social, cuja organização institucional está acontecendo mais recentemente na evolução das políticas sociais brasileiras.

Ao analisar a relação dos governos estaduais com o SISAN, observa-se que, ao final do ano de 2014, 100\% afirmavam ter Conselho e Câmara Intersetorial. No entanto, somente 29,6\%, equivalente a oito Estados, atendiam aos três critérios de adesão ao sistema e simultaneamente possuíam lei estadual. Ressalta-se que dos oito Estados, três encontram-se na região Nordeste e dois na região Centro-Oeste (Tabela $3)$. 
Tabela 03. Número e Percentual de Estados que informam a existência de conselho, câmara e plano de SAN simultaneamente. Por regiões e Brasil. ESTADIC, 2014.

\begin{tabular}{llll}
\hline Brasil/Região & UF /Total & UF com Conselho, Câmara e Plano \\
& & Número & Percentual \\
\hline Norte & 7 & 1 & 3,7 \\
Nordeste & 9 & 3 & 11 \\
\hline Sudeste & 4 & 1 & 3,7 \\
Sul & 3 & 1 & 3,7 \\
Centro-Oeste & 4 & 2 & 7,5 \\
Brasil & 27 & 8 & 29,6 \\
\hline
\end{tabular}

Fonte: Autora

Ao verificar a existência de Câmara ou instância governamental intersetorial de segurança alimentar e nutricional, por área de governo representada, observa-se que agricultura, educação e saúde estão representadas em todas as entidades federativas, e a assistência social está em $81 \%$, o planejamento em $74 \%$ e a Casa Civil, como esfera de comando do governo executivo, em 55\%. A presença da área de segurança alimentar e nutricional como componente da Câmara é reportada em $48 \%$ dos Estados, mostrando a existência de um representante especifico para a SAN. A pesquisa revela o envolvimento expressivo de áreas que fazem a mediação da SAN enquanto campo disciplinar e também enquanto setores da administração pública federal que estiveram fortemente presentes no debate e construção conceitual do SISAN, como é o caso de segmentos da agricultura familiar, da educação e da saúde.

Cerca de $90 \%$ dos Estados brasileiros afirmam ter recursos próprios para apoiar o funcionamento das estruturas institucionais da política de segurança alimentar nutricional. Entretanto, 11 Estados destinam recursos para apoiar o funcionamento de conselhos e câmaras e outros 11 apoiam apenas os conselhos, enquanto que em um deles os recursos destinam-se apenas à instância governamental intersetorial.

Ao observar as ações desenvolvidas com recursos próprios estaduais, é 
informado como sendo as de maior frequência, ao se considerar o total de ações realizadas no Brasil, as atividades de educação alimentar (15\%), seguida de atividades de capacitação e fomento à produção orgânica (13\%), manutenção de restaurantes populares (12\%), manutenção de equipamentos de abastecimento público de alimentos (11\%), implantação de tecnologias de acesso à agua para consumo humano (10\%) e doação de alimentos (10\%). (Tabela 3).

O financiamento de ações do governo federal por sua vez aponta para a priorização das atividades de capacitação e fomento à produção orgânica seguida da implantação de tecnologias de acesso à agua para consumo humano manutenção de feiras livres e doação de alimentos.

Em percentuais, Centro-Oeste, Sul e Nordeste são as regiões que possuem o maior número de Estados com financiamento federal das atividades de fomento à produção orgânica. A região Nordeste é aquela onde o maior número absoluto de Estados recebe recursos para implantação de tecnologias de acesso a agua, seguido do Norte, Sul e Sudeste. 
Tabela 04. Número de Estados Por Ação Desenvolvida Com Recurso Próprio. Região e Brasil - ESTADIC 2014

\begin{tabular}{|c|c|c|c|c|c|c|c|c|c|c|c|c|}
\hline \multirow{3}{*}{$\begin{array}{l}\text { Atividades desenvolvidas com } \\
\text { recurso próprio }\end{array}$} & \multicolumn{12}{|c|}{ Região } \\
\hline & \multicolumn{2}{|c|}{ Norte } & \multicolumn{2}{|c|}{ Nordeste } & \multicolumn{2}{|c|}{ Sudeste } & \multicolumn{2}{|c|}{ Sul } & \multicolumn{2}{|c|}{ Centro-Oeste } & \multicolumn{2}{|c|}{ Brasil } \\
\hline & Freq. & $\begin{array}{l}\text { \% por } \\
\text { Região }\end{array}$ & Freq. & $\begin{array}{l}\text { \% por } \\
\text { Região }\end{array}$ & Freq. & $\begin{array}{l}\text { \% por } \\
\text { Região }\end{array}$ & Freq. & $\begin{array}{l}\text { \% por } \\
\text { Região }\end{array}$ & Freq. & $\begin{array}{l}\text { \% por } \\
\text { Região }\end{array}$ & Freq. & $\%$ Total \\
\hline $\begin{array}{l}\text { Educação Alimentar e } \\
\text { Nutricional }\end{array}$ & 5 & 20,00 & 7 & 15,22 & 2 & 12,50 & 2 & 14,29 & 2 & 10,53 & 18 & 15,00 \\
\hline $\begin{array}{l}\text { Capacitação, fomento ou } \\
\text { incentivo à produção orgânica } \\
\text { e/ou agroecológ. }\end{array}$ & 4 & 16,00 & 5 & 10,87 & 3 & 18,75 & 1 & 7,14 & 3 & 15,79 & 16 & 13,33 \\
\hline Doação de alimento & 3 & 12,00 & 3 & 6,52 & 2 & 12,50 & 1 & 7,14 & 3 & 15,79 & 12 & 10,00 \\
\hline $\begin{array}{l}\text { Manutenção de feiras livres/ } \\
\text { populares ou merc. públicos de } \\
\text { alimentos }\end{array}$ & 1 & 4,00 & 5 & 10,87 & 2 & 12,50 & 0 & - & 2 & 10,53 & 10 & 8,33 \\
\hline $\begin{array}{l}\text { Manutenção de bancos de } \\
\text { alimentos }\end{array}$ & 0 & - & 1 & 2,17 & 1 & 6,25 & 2 & 14,29 & 2 & 10,53 & 6 & 5,00 \\
\hline $\begin{array}{l}\text { Manutenção de cozinhas } \\
\text { comunitárias }\end{array}$ & 0 & - & 3 & 6,52 & 0 & - & 1 & 7,14 & 1 & 5,26 & 5 & 4,17 \\
\hline $\begin{array}{l}\text { Manutenção de restaurantes } \\
\text { populares }\end{array}$ & 3 & 12,00 & 7 & 15,22 & 1 & 6,25 & 2 & 14,29 & 2 & 10,53 & 15 & 12,50 \\
\hline $\begin{array}{l}\text { Manutenção de Equipamentos de } \\
\text { abastecimento público }\end{array}$ & 3 & 12,00 & 5 & 10,87 & 2 & 12,50 & 2 & 14,29 & 2 & 10,53 & 14 & 11,67 \\
\hline $\begin{array}{l}\text { Implantação de tecnolog. acesso } \\
\text { à água p/ cons. humano } \\
\text { (cisternas) }\end{array}$ & 4 & 16,00 & 4 & 8,70 & 2 & 12,50 & 3 & 21,43 & 0 & - & 13 & 10,83 \\
\hline Atividades de agricultura urbana & 2 & 8,00 & 6 & 13,04 & 1 & 6,25 & 0 & - & 2 & 10,53 & 11 & 9,17 \\
\hline Total & 25 & 100,00 & 46 & 100,00 & 16 & 100,00 & 14 & 100,00 & 19 & 100,00 & 120 & 100,00 \\
\hline
\end{tabular}

Fonte: Autora 
Ao analisar se a existência do SISAN estava associada à execução das atividades mencionadas pelas unidades federadas, por meio da aplicação do teste exato de Fisher para cada uma das atividades, verificou-se que não houve associação entre as variáveis. Entretanto, tal informação requer uma análise de tendência e uma avaliação utilizando outros indicadores e testes estatísticos mais robustos antes que seja seguro afirmar que não há influência do SISAN sobre o comportamento da gestão estadual, no que tange às ações analisadas. Neste sentido, numa linguagem baseada em avaliação de programa, pode-se inferir que a temporalidade da implantação de SAN nos estados ainda não permite uma avaliação de correlação de impacto.

\subsection{Panorama Municipal de Implantação do SISAN}

Ao observar a existência de estrutura de governo para a gestão da SAN verifica- se que 39,5\% dos municípios informam possuir tal estrutura ou como órgão específico ou como órgão compartilhado ou como setor subordinado a outra secretaria, ou ainda como órgão subordinado diretamente ao poder executivo local. Entre os municípios que informam a estrutura de SAN, o maior percentual é registrado na região Norte $(45,1 \%)$, seguido do Nordeste $(43,0 \%)$, Sudeste $(38,5 \%)$, Sul $(37,9 \%)$ e Centro Oeste $(29,12 \%)$.

Ao olhar o porte do município, 92,3\% dos municípios acima de 500 mil habitantes informam a existência de estrutura de SAN. Este percentual cai para 67,8\% nos municípios entre 101 e 500 mil habitantes, para 52\% naqueles entre 51 e 100 mil habitantes e 43,6\% dos municípios entre 21 e 50 mil habitantes. Entre os municípios abaixo de 50 mil habitantes o percentual situa-se na faixa de $34,8 \%$.

A pesquisa aponta que entre os municípios respondentes, a existência de conselho é registrada em $29 \%$ dos municípios, lei municipal em 17,3\%, câmara intersetorial em 7,6\%, e plano, em $8,4 \%$ dos municípios.

Entre os municípios que informam a existência de conselho, verifica-se que em $80 \%$ deles, os conselhos têm caráter consultivo. Esta atribuição pode ser acrescida da função deliberativa $(61,2 \%)$, fiscalizadora $(52,6 \%)$ e normativa $(32,2 \%)$.

O IBGE define conselho consultivo como aquele em que seus integrantes têm o papel apenas de estudar e indicar ações ou políticas sobre sua área de atuação; deliberativo, aquele que efetivamente tem poder de decidir sobre a implantação de políticas e/ou a administração de recursos relativos à sua área de atuação; fiscalizador, aquele que fiscaliza a implementação e o funcionamento de políticas e/ou a administração de recursos relativos à sua área de atuação e normativo, como sendo aquele que estabelece normas e diretrizes para as políticas e/ou a administração de recursos relativos à sua área de atuação. 
Ao analisar a combinação dos critérios de adesão ao SISAN, observa-se que este tal qual desenhado no Decreto 7272/20109 encontra-se estruturado em 1,7\% dos municípios brasileiros. A região Norte reúne esta condição em 3,3\% de seus municípios, seguidos da Região Nordeste $(1,8 \%)$ Região Sul (1,7\%), Região Sudeste $(1,3 \%)$ e Centro Oeste $(0,9 \%)$.

Quanto ao órgão de coordenação do SISAN observa-se que em $45 \%$ dos munícipios, a estrutura administrativa de SAN está vinculada ao setor da assistência social; em $21 \%$ de municípios a estrutura vincula-se ao setor da saúde e em 13\% dos municípios onde a área está associada à agricultura. Setores como planejamento e direitos humanos aparecem em menores percentuais (Tabela 5). 
Tabela 5. Relação de Secretaria e ou Setor ao qual a SAN se encontra vinculada, em número absoluto e percentual. Por municípios, região e Brasil. 2014*.

\begin{tabular}{|c|c|c|c|c|c|c|c|c|c|c|c|c|}
\hline \multirow{3}{*}{$\begin{array}{c}\text { Setor ou } \\
\text { Secretaria }\end{array}$} & \multicolumn{12}{|c|}{ Região } \\
\hline & \multicolumn{2}{|c|}{ Norte } & \multicolumn{2}{|c|}{ Nordeste } & \multicolumn{2}{|c|}{ Sudeste } & \multicolumn{2}{|l|}{ Sul } & \multicolumn{2}{|c|}{ Centro - Oeste } & \multicolumn{2}{|c|}{ Brasil } \\
\hline & Frequência & $\begin{array}{l}\% \text { por } \\
\text { região }\end{array}$ & Frequência & $\begin{array}{l}\% \text { por } \\
\text { região }\end{array}$ & Frequência & $\begin{array}{l}\% \text { por } \\
\text { região }\end{array}$ & Frequência & $\begin{array}{l}\% \text { por } \\
\text { região }\end{array}$ & Frequência & $\begin{array}{l}\% \text { por } \\
\text { região }\end{array}$ & Frequência & $\begin{array}{l}\% \text { por } \\
\text { região }\end{array}$ \\
\hline $\begin{array}{l}\text { Assistência } \\
\text { Social }\end{array}$ & 121 & 53,30 & 463 & 53,46 & 273 & 39,00 & 230 & 40,85 & 1142 & 45,85 & 2229 & 45,99 \\
\hline Agricultura & 22 & 9,69 & 107 & 12,36 & 104 & 14,86 & 77 & 13,68 & 322 & 12,93 & 632 & 13,04 \\
\hline Planejamento & 2 & 0,88 & 4 & 0,46 & 7 & 1,00 & 5 & 0,89 & 19 & 0,76 & 37 & 0,76 \\
\hline $\begin{array}{l}\text { Saúde } \\
\text { Direitos }\end{array}$ & 46 & 20,26 & 185 & 21,36 & 151 & 21,57 & 115 & 20,43 & 537 & 21,56 & 1034 & 21,33 \\
\hline Humanos & 5 & 2,20 & 3 & 0,35 & 4 & 0,57 & 4 & 0,71 & 17 & 0,68 & 33 & 0,68 \\
\hline Outros/diversos & 31 & 13,66 & 104 & 12,01 & 161 & 23,00 & 132 & 23,45 & 454 & 18,23 & 882 & 18,20 \\
\hline Total & 227 & 100 & 866 & 100 & 700 & 100 & 563 & 100 & 2491 & 100 & 4847 & 100 \\
\hline
\end{tabular}

Fonte: Autora 
Ao associar os municípios que cumprem os requisitos de adesão ao SISAN e o setor de coordenação do SISAN, verifica-se que municípios que informaram a existência de conselho, câmara intersetorial e plano estão mais associados à existência de órgão gestor de assistência social e de saúde do que aqueles que não atendem os três critérios $(\mathrm{p}<0,0001)$.

Outro aspecto investigado pela MUNIC/2014 foi à existência de recursos orçamentários próprios para financiamento da política de segurança alimentar e nutricional. O resultado aponta para existência de orçamento municipal para SAN em apenas 13,5\% dos municípios.

Entre os municípios que informam desenvolver ações com recursos próprios, as ações de manutenção de feiras livres aparecem como sendo as mais executadas. Ao analisar o repasse do governo federal verifica-se que a atividade prioritária é a Implantação de tecnologias de acesso à água para consumo humano (cisternas) Destes, 82,3\% municípios concentram- se no Nordeste brasileiro. Quanto às atividades executadas pelos municípios em função da origem de recursos, verifica-se que as atividades financiadas com recursos federais e estaduais se concentram na implantação de cisternas. Os recursos municipais concentram-se na manutenção de feiras e mercados públicos de alimentos, seguido das atividades de agricultura urbana.

\subsection{Olhares Cruzados}

Dentre os resultados encontrados destacou-se que a organização de conselhos municipais de SAN foi observada em um terço dos municípios brasileiros. Tal desfecho pode ser atribuído a uma expressiva mobilização em torno do modelo de democracia participativa, desenhado pela Constituição Federal de 1988 e aprofundada pelo governo federal nos últimos dez anos.

A participação social tornou-se fundamento dos mecanismos institucionais que visam garantir direitos sociais consagrados constitucionalmente. Entre estes o exercício do direito à alimentação, introduzido no artigo $6^{\circ}$ pela Emenda Constitucional $\mathrm{n}^{\circ}$ 64, de 4 de fevereiro de 2010, após intensa mobilização da sociedade civil foi de fundamental importância para um país tão marcado pelas desigualdades sociais. A campanha pela inclusão da alimentação na Constituição foi liderada pelo Conselho Nacional de Segurança Alimentar e Nutricional e sua aprovação trouxe implicações para os entes federados que passam a partilhar com a união a responsabilidade de construção do SISAN (MALUF, 2010). 
O CONSEA, juntamente com o Mapa da Fome e o Movimento de Ação da Cidadania contra a Fome a Miséria, é apontado como um dos marcos da construção do Sistema de SAN, conforme aponta Nascimento (2009) Os números levantados evidenciam que o conselho parece ser um dos principais mecanismos institucionais que, no período analisado, responde pelo modelo de participação social adotado pelas políticas sociais do governo federal como também pela indução da descentralização do SISAN.

O modelo adotado para a implantação dos conselhos mostra que o caráter consultivo tem primazia sobre as demais atribuições, seguindo a tendência do próprio CONSEA nacional. Há discussões sobre se a função consultiva limita ou não a atuação e a influência do conselho sobre a política e se um caráter deliberativo não ampliaria o impacto da agenda de SAN. O argumento é contestado, uma vez que o caráter consultivo e propositivo do CONSEA facilita o trânsito e o diálogo entre setores que compõe a SAN, possibilitando uma maior inserção da agenda de SAN (LEÃO, 2012).

Ao retomar a trajetória histórica da SAN, a criação do Movimento da Ação da Cidadania Contra a Fome, a Miséria e pela Vida com objetivo de mobilizar a sociedade para a questão social da pobreza e fome, em grande parte pode ser associada à expansão atual do SISAN, via implantação de conselhos. Na ocasião, como aponta Vasconcellos (2005) em apenas um ano foram criados mais de cinco mil comitês da Ação da Cidadania, mostrando uma resposta rápida e vigorosa da sociedade civil.

O expressivo número de conselhos municipais implantados, quando comparado as demais estruturas de SAN, se aproxima desta intensa mobilização e pode ser considerada expressão da sensibilidade da sociedade civil com o tema da segurança alimentar e nutricional. Supera o entendimento anterior marcado pela emergência do

combate à fome e conforme uma compreensão sobre a necessidade de um modelo alimentar aliado à sustentabilidade ambiental e à saúde, objetivo final da SAN.

A coordenação do SISAN no âmbito de Estados e municípios mostra traços peculiares que remontam a trajetória institucional de políticas anteriormente implantadas. O setor de assistência social aparece como sendo coordenador do SISAN na maioria dos Estados e mais da metade dos municípios. Na escala estadual, a agricultura aparece como sendo o segundo setor de coordenação do 
SISAN. Já na esfera municipal, setores da saúde e da agricultura se distribuem entre o segundo e o terceiro setor de coordenação mais frequente.

São inegáveis os esforços recentes de implantação do Sistema Único de Assistência Social. Em 2005, foi aprovada a Norma Operacional de Assistência Social (BRASIL, 2005) organizando as atribuições federativas e o financiamento do Sistema, o que viabilizou sua expansão, quase ao mesmo tempo em que o arcabouço institucional do SISAN vinha sendo construído sob a égide do mesmo órgão federal, o Ministério de Desenvolvimento Social e Combate à Fome. Portanto, não é estranho que o setor da assistência venha abraçando a coordenação da política de SAN tanto no nível estadual quanto no nível municipal.

Por sua vez, a presença do setor da agricultura como órgão de coordenação do SISAN no nível estadual mereceria um olhar aprofundado sobre a organização institucional do nível federal no que tange a política agrícola e rural. Duas instâncias federais dividem as ações voltadas para a agricultura, sendo que o Ministério da Agricultura, Pecuária e Abastecimento responde pela competitividade do agronegócio, sua regulação buscando promover o desenvolvimento sustentável e o Ministério do Desenvolvimento Agrário responde pela política de desenvolvimento do Brasil rural, inclusão produtiva da agricultura familiar e regularização da terra, ambos com assento na CAISAN.

O conflito entre modelos produtivos intensivistas de exportação e de valorização do produtor familiar voltado para o abastecimento interno, embora tenham sido apartados no âmbito institucional, tencionam a todo o momento o debate sobre o modelo de produção de alimentos baseado no ideário da SAN.

Os dois ministérios têm assento no CONSEA nacional e na CAISAN embora a agenda da agricultura familiar e da inclusão produtiva seja valorizada como ação de convergência de SAN para a construção do sistema. A presença departamentalizada de segmentos da agricultura intensiva e da agricultura familiar uma única autarquia, no âmbito estadual, poderia explicar a coordenação do SISAN pelo setor de agricultura. Mas somente uma análise especifica sobre a estruturação institucional e sobre qual segmento se faz presente na coordenação do sistema, pode responder adequadamente tal achado.

A presença significativa da Saúde como setor de coordenação do SISAN na esfera municipal não surpreende. A Saúde é um dos setores que mais avançaram na descentralização da gestão e a organização da atenção primária teve grande 
impulso nos últimos anos, com aumento do financiamento e investimento na qualificação do trabalho das unidades básicas de saúde, considerados portas de entrada do SUS. Além disso, a Alimentação e Nutrição faz parte das políticas universais da saúde conferindo ao tema uma inserção no território local (BRASIL, 2012).

Ainda na esfera estadual, ao relacionar a existência do SISAN, entendendoo como a presença dos três critérios de implantação definidos pelo governo federal, com a realização de ações com recursos estaduais e com recursos transferidos do governo federal, verifica-se que não há associação entre estes. Configura-se assim o entendimento que as ações executadas estão em linha com as previstas pelo nível federal (elencadas na MUNIC) independente de se vincularem ou não formalmente a presença do SISAN.

O comportamento de Estados e municípios quanto à implantação das Câmaras Intersetoriais é distinto. Enquanto $100 \%$ dos Estados possuem câmaras instaladas, somente $7,6 \%$ dos municípios afirmam ter a instancia intersetorial, o que a transforma em fator limitante da expansão do SISAN nesta esfera administrativa.

Tanto a descentralização como a intersetorialidade são percebidos como novos paradigmas da gestão pública e encontram-se associadas a uma lógica de identificação de problemas que parte das demandas e necessidades da população. A intersetorialidade rompe com a lógica fragmentada da gestão e traz à tona questões que se encontram sob a governabilidade do poder público municipal, tornando-a um tema sensível na abordagem da política local (JUNQUEIRA, 2000).

A intersetorialidade é uma decisão política que, pelos números da MUNIC/2014 pode ainda estar longe de ser alcançada pela gestão municipal. Para o SISAN, investir em mecanismos que aprofundem a ação intersetorial e a descentralização parece ser o caminho para produzir uma institucionalidade enraizada no âmbito nacional.

A combinação simultânea dos três critérios reafirma o cenário de limitada adesão ao SISAN indicando, uma baixa capacidade de descentralização do sistema. Apreende- se ademais que este achado aponta para a priorização federal na construção do sistema em articulação direta com os movimentos sociais nacionalmente representados, acontecendo em fase posterior a organização de um arranjo federativo que propiciasse na escala estadual e municipal a necessária 
sustentação ao SISAN.

Se há vantagens em organizar o sistema a partir das premissas do governo federal, com a inclusão de agendas mais globais e consequente inserção do país em fóruns internacionais relevantes, a opção adotada pode trazer riscos ao enraizamento do sistema, no que se refere ao fortalecimento de um pacto federativo em torno de SAN. Caso não se disponha de mecanismos institucionais fortes de base municipal e estadual que garantam uma atuação independentemente do movimento civil organizado nacionalmente e dos estímulos financeiros do governo central, qualquer alteração na prioridade política de governo pode dificultar o avanço do SISAN.

O SISAN vem se descentralizando? Institucionalizando? Ao o os números analisados, pode-se dizer que desde sua criação até 2014 os critérios de implantação foram cumpridos incipientemente por Estados e municípios.

Embora todos os Estados da federação informem possuir estrutura organizacional para tratar da Política Nacional de Segurança Alimentar e Nutricional, o cenário é bastante diferente ao olhar os municípios. Dos 5.570 municípios, somente $40 \%$ deles informam ter órgão gestor de SAN.

A pluralidade de setores que abriga a área de SAN tanto nos Estados como nos municípios, vinculada ora à assistência social, ora à agricultura, ora à saúde, não permite ainda apontar características institucionais próprias ao SISAN. Não é possível explicitar a partir dos elementos analisados como será estabelecido o arranjo local que irá assumir a coordenação do sistema e quais interesses e valores dos agentes que estarão à frente do SISAN nos níveis subnacionais.

Mas determinadas características se sobressaem. A coordenação local a cargo da assistência social e da saúde correlaciona-se positivamente à implantação do SISAN, considerando as regras formais de adesão ao Sistema. Os dois setores organizados por meio de uma lei orgânica e da criação de sistemas únicos, hierarquizados e descentralizados parecem influenciar movimentos sociais e gestão local em direção à adesão ao SISAN. Como afirma Takagi (2012) não se constitui em novidade registrar que a própria implantação do SISAN seguiu caminho semelhante

aos setores da Assistência Social e Saúde, embora ambos com experiências bem distintas. A semelhança quanto à organização e logica sistêmica está presente, mas a materialidade de serviços que a população pode buscar permanece como 
elemento de diferenciação entre os sistemas.

A área da saúde conta com intensa participação da sociedade civil, que em grande medida esteve na origem da articulação e configuração das políticas de SAN e do SISAN. Ao mesmo tempo, a questão da fome é um desafio a ser enfrentado no âmbito do conjunto de mínimos sociais, a que têm direito todos os cidadãos, como afirma a Lei Orgânica da Assistência Social - LOAS (RIGON e BOGUS, 2016; YASBECK, 2004)

Se o sistema vem se constituindo localmente na confluência dos segmentos da assistência social e da saúde como fiadores das regras de adesão e implantação do SISAN, é essencial que a agenda da produção sustentável de alimentos e da construção de sistema alimentar agroecológico e justo esteja presente também no nível local. Para tal, muito da força de articulação da sociedade civil deverá se voltar para a consolidação de agendas locais urbanas e rurais que coloquem a temática alimentar no centro das questões locais e territoriais.

A formação de conselhos em quase um terço dos municípios é emblemática. Os conselhos compõem a esfera pública, sendo um espaço de encontro entre cidadãos e Estado sendo que é no âmbito da gestão municipal, que a participação social pode transformar as práticas clientelistas que fazem parte da herança da administração pública no Brasil. Assim, os conselhos podem tanto expressar a intensidade da participação social ou representar a promoção de alguns interesses particulares em detrimento de outros, colocando em risco a democratização desejada (OLIVEIRA, 2010; RAICHELIS, 2000).

Somente o tempo apontará o grau de representatividade e de capacidade das instancias de participação social em SAN em influenciar a política local e nacional. O que se pode afirmar, é que a presença dos conselhos como instancia numericamente superior as demais, pode trazer vitalidade ao SISAN, mas não permite afirmar que a democracia na gestão do sistema esteja consolidada, sendo, portanto, uma tarefa cotidiana de superação das contradições da nossa sociedade.

Novos estudos podem decifrar se o cenário institucional que se desenha para SAN responde à construção do SISAN na perspectiva apontada pelos princípios e

diretrizes originais da política, se atende aos diferentes projetos de SAN e se permite uma evolução institucional que atenda as dimensões presentes na Política de SAN. 
$\mathrm{Na}$ análise realizada aqui, o cenário subnacional não parece propicio. A heterogeneidade de setores e uma falta de alinhamento de prioridades pode ocasionar uma rotatividade nos grupos de interesse que impulsionam estes setores fazendo como que a participação e a tomada de decisões compartilhadas sejam afetadas, com a dominância de um ou outro segmento conforme a agenda.

Os resultados mostram ainda que não há um papel indutor significativo por parte do nível federal que permita acelerar a expansão do SISAN. Considerando que o sistema teve uma construção histórica participativa, mas com forte organização incidindo no governo federal, mecanismos mais efetivos de descentralização que ampliem a base municipal do sistema precisam ser desenhados com objetivo de consolidar a identidade e conferir capilaridade a SAN no país. 


\section{Capítulo 4 - Percepção dos Atores Sobre a Construção do SISAN}

\subsection{Referenciais para Análise de Conteúdo das Entrevistas}

O desafio desta etapa da pesquisa foi estabelecer os documentos essenciais a serem lidos, uma vez que ao mesmo tempo: “A análise pode efetuar-se numa amostra desde que o material a isso se preste. A amostragem diz-se rigorosa se a amostra for uma parte representativa do universo inicial" (BARDIN, 2009, P.123) e o universo de SAN está contido em documentos das mais diversas origens: conferências, conselhos, leis e políticas, colegiados de governo, sociedade civil, bem como outros espaços institucionais que descrevem o conteúdo emitido no processo de comunicação sobre SAN.

Assim, optou-se pela análise dos documentos referentes aos dos relatórios finais e declarações políticas das Conferências nacionais com objetivo de identificar as ideias presentes sobre a institucionalidade da SAN. A leitura da Lei Orgânica de Segurança Alimentar de 15 de setembro de 2006 e dos Decretos nº 6.272 e 6.273 de 23 de novembro de 2007, e Decreto $\mathrm{n}^{\circ} 7.272$ de 10 de agosto de 2010, como marco legal que organiza o SISAN, embasaram a análise posterior. A partir destes, foi realizada a leitura das Resoluções emitidas pelo colegiado de governo e o plano intersetorial, que foram consultados para identificar a resposta oficial às demandas da SAN. E por fim, foram relacionados os temas da Exposições de Motivos elaboradas pelo CONSEA.

Mediante a leitura dos documentos evidenciou-se que o marco decisivo, proposto pela sociedade civil para configurar a SAN no Estado brasileiro, foi o relatório final produzido pela Conferência de Segurança Alimentar do ano de 2004. O objetivo expresso no título da Conferência "A construção da política nacional de segurança alimentar e nutricional" esclarece a intencionalidade da incorporação da agenda de SAN no campo das políticas públicas governamentais. É importante marcar este aspecto, pois como abordado em capítulos anteriores, o debate sobre a SAN como estratégia de desenvolvimento nacional e mesmo como princípio norteador das diversas políticas relacionadas ao campo do acesso, produção e consumo de alimentos no país estiveram presentes nos debates sobre o tema tanto no âmbito acadêmico como no cenário público. 


\subsection{Identificação de Categorias}

O escopo das resoluções emitidas pela CAISAN (quadro 6) e das exposições de motivos emanadas pelo CONSEA (quadro 7) permitiram traçar os assuntos de interesse e os instrumentos institucionais usados para efetivar o SISAN. A análise dos documentos das Conferências Nacionais permitiu identificar a partir dos temas abordados, as ideias que as orientaram e paulatinamente conformam o ideário com que a SAN se coloca no cenário de governo conforme apresenta os Quadros 8 e 9.

Fruto do debate, orientado pelo documento de referência da $2^{\mathrm{a}} \mathrm{CNSAN}$ de autoria de Francisco Menezes, na ocasião presidente do CONSEA e dos professores Renato Maluf da Universidade Federal Rural do Rio de Janeiro e Luciene Burlandy da Universidade Federal Fluminense, o relatório final da Conferência consagra os principais aspectos da institucionalização da SAN.

Entre eles, o direito humano à alimentação e o acesso universal aos alimentos como princípios orientadores da política de SAN; a construção de planos intersetoriais como estratégia para alcançar a transversalidade das ações; a elaboração de uma lei orgânica que considere as questões de abastecimento e a instituição de um sistema nacional sustentável, que regule as políticas de SAN e tenha orçamento próprio com a criação de fundo específico e com definição do papel dos diferentes níveis de governo e com mecanismos para condicionar o repasse de recursos a Estados e munícipios, com a fiscalização do CONSEA; a participação ativa da sociedade civil na elaboração e aprovação da Lei Orgânica e mecanismos de acompanhamento e controle social.

Em 2006, com a publicação da Lei Orgânica de SAN, reitera-se a garantia do direito humano à alimentação adequada como finalidade do Sistema, elencando as diversas dimensões da SAN e definindo os órgãos e entidades que integram o SISAN, a saber: Conferência, CONSEA e CAISAN, órgãos e entidades federais, estaduais e municipais de SAN, e instituições privadas.

O instrumento utilizado pelo CONSEA para levar suas proposições ao governo federal, em especial à Presidência da República, ao qual é ligado diretamente é a Exposição de Motivos acerca de demandas sociais que são apresentadas, debatidas e acordadas com representantes de governo presentes no conselho. Durante o período estudado, foi possível identificar 180 exposições de motivos classificadas por temas de interesse. 
Quadro 07 - Relação Temática das Exposições de Motivos elaboradas pelo CONSEA $2004-2014$

\begin{tabular}{|c|c|}
\hline TEMÁTICAS & $\begin{array}{l}\mathbf{N}^{0} \text { DE } \\
\text { EXPOSIÇÕES DE } \\
\text { MOTIVO }\end{array}$ \\
\hline SISAN E PARTICIPAÇÃO SOCIAL & 35 \\
\hline AGRICULTURA FAMILIAR & 27 \\
\hline AGROTOXICO, CTNBIO E CONTAMINAÇÃO. & 20 \\
\hline PNAE PAA BOLSA FAMILIA E CISTERNAS & 17 \\
\hline ORÇAMENTO DE SAN & 14 \\
\hline ASSUNTOS INTERNACIONAIS & 13 \\
\hline $\begin{array}{c}\text { AMBIENTE, DIVERSIDADE } \\
\text { AGROECOLOGIA. }\end{array}$ & 13 \\
\hline $\begin{array}{c}\text { ABASTECIMENTO, AGRICULTURA } \\
\text { EMBRAPA. }\end{array}$ & 12 \\
\hline POVOS TRADICIONAIS & 12 \\
\hline $\begin{array}{lll}\text { SAUDE, } & \text { NUTRIÇÃO } & \text { E } \\
& \text { EDIMENTAR. } & \end{array}$ & 11 \\
\hline DIVERSOS & 06 \\
\hline TOTAL & 180 \\
\hline
\end{tabular}

Fonte: A autora baseada nas informações disponíveis no endereço eletrônico:

http://www4.planalto.gov.br/consea

Temas afetos diretamente ao aspecto institucional do SISAN referentes aos mecanismos de participação e proposições orçamentarias somam 49 Exposições de motivos, quase $1 / 3$ do total produzido pelo CONSEA. A diversidade dos temas reflete a composição setorial presente no conselho e sua capacidade e influência na construção da agenda da SAN a partir da sociedade.

A $3^{\text {a }}$ Conferência, realizada em 2007, busca avançar nos temas e programas relevantes alinhavando possíveis objetivos e estratégias para a política de SAN. Nesse sentido, colocam na dimensão de acesso, as estratégias de geração de trabalho e renda e programas de acesso à renda e alimentos. Na dimensão de sistemas de produção, 
alinham- se propostas de reformar agraria, incentivo a agricultura familiar, política de abastecimento, regulação de serviços ambientais e controle de agrotóxicos. Mudanças nas diretrizes curriculares, valorização cultural da alimentação, capacitação de profissionais dos sistemas de políticas públicas e uma agenda de pesquisa integra a orientação de manter processos de educação permanente em SAN. Estratégias diferenciadas para comunidades tradicionais em diferentes políticas publicam respondem pelo anseio de equidade da política de SAN. Aspectos referentes ao consumo de alimentos, integrando dimensões biológicas, sanitárias e sociais são retomadas na ideia de fortalecer as ações de nutrição do SUS. E por fim, a soberania alimentar nas ações internacionais é valorizado como componente da cooperação sul- sul. A abrangência e a profundidade das proposições aprovadas em Conferência revelam a capacidade de formulação e de articulação presentes do conjunto de atores de SAN para impulsionar a ação política do governo.

O Decreto $n .{ }^{0} 7.272$ de 2010 incorpora as diretrizes e objetivos emanados da Conferência e do CONSEA, adota como mecanismo de gestão a adesão pactuada ao SISAN com cumprimento de requisitos mínimos, já abordados em capítulos anteriores. Aponta que união, Estados e municípios participam do financiamento do sistema, não estabelecendo, no entanto, a criação de fundos específicos de SAN, como demandado nas Conferências de SAN. Outro ponto importante é a afirmação de que o plano deve ser resultado de articulação intersetorial, sendo reconhecidamente o instrumento de planejamento, gestão e execução da PNSAN.

Dá competência ao CONSEA para apreciação e acompanhamento da elaboração do Plano Nacional de Segurança Alimentar e Nutricional e manifestação sobre o seu conteúdo final, bem como avaliação da sua implementação e contribuição para a proposição e disponibilização de mecanismos e instrumentos de exigibilidade do DHAA e monitorar sua aplicação. Acrescenta como atribuição da CAISAN, a instituição e coordenação de fóruns tripartites com representantes das câmaras governamentais intersetoriais de SAN e das respectivas políticas e planos de segurança alimentar e nutricional.

O regimento interno da CAISAN, aprovado ainda em 2010 (Resolução $\mathrm{n}^{\circ} 4 / 2010$ ), estabeleceu uma estrutura organizacional hierarquizada. Foram estabelecidos um pleno ministerial, um pleno executivo, uma secretaria executiva e comitês técnicos. A secretaria executiva e a presidência são exercidas pelo MDS. 
Cabe

ao pleno executivo elaborar a proposta do plano e definir as ações orçamentarias que irão compor o orçamento da SAN. No entanto, resolução seguinte do mesmo ano, indica um comitê técnico para coordenar o processo de elaboração do Plano Nacional de SAN. O comité é composto por representantes técnicos de 09 ministérios. O Quadro abaixo reúne as resoluções emitidas pela CAISAN no período mais recente do estudo. 
Quadro 8 - Resoluções emitidas pela CAISAN, por assunto no período de 2009 a 2014.

\begin{tabular}{|c|c|c|}
\hline $\begin{array}{l}\text { RESOLUÇÃO/ } \\
\text { ANO }\end{array}$ & EMENTA & ENCAMINHAMENTOS \\
\hline $1 / 2009$ & CT para elaborar I Balanço das ações de SAN & Documento \\
\hline $2 / 2009$ & CT para elaborar Política e Plano de SAN & Decreto 7272/10 (PNSAN) \\
\hline $3 / 2010$ & $\begin{array}{l}\text { CT para elaborar I Plano de } \\
\text { SAN }\end{array}$ & Publicação DOU (2012) \\
\hline $4 / 2010$ & Regimento Interno & $\begin{array}{l}\text { Publicação } \\
\text { DOU }\end{array}$ \\
\hline $5 / 2010$ & $\begin{array}{l}\text { CT para coordenar Plano de } \\
\text { SAN }\end{array}$ & Publicação DOU (2012) \\
\hline $6 / 2011$ & CT para acompanhar PL da Política de Abastecimento & S/Informação \\
\hline $8 / 2011$ & $\begin{array}{lll}\text { CT para } & \text { organização } & \text { da CNSAN }\end{array}$ & Documento da CNSAN \\
\hline 9/2011 & Procedimentos e conteúdo para adesão ao SISAN & $\begin{array}{l}\text { Publicação } \\
\text { DOU }\end{array}$ \\
\hline $1 / 2012$ & $\begin{array}{l}\text { Institui o I Plano Nacional de Segurança Alimentar e Nutricional - PLANSAN } \\
\text { 2012/2015. }\end{array}$ & $\begin{array}{l}\text { Publicação } \\
\text { DOU }\end{array}$ \\
\hline
\end{tabular}




\begin{tabular}{|c|c|c|}
\hline $1 / 2013$ & $\begin{array}{l}\text { Formaliza a adesão do (s) Município (s) ao Sistema de Segurança Alimentar e } \\
\text { Nutricional. }\end{array}$ & $\begin{array}{l}\text { Publicação } \\
\text { DOU }\end{array}$ \\
\hline $2 / 2014$ & $\begin{array}{l}\text { Aprova o Regimento Interno da Câmara Interministerial de Segurança } \\
\text { Alimentar e Nutricional - CAISAN, criada pelo Decreto } \mathrm{n}^{\circ} 6.273 \text {, de } 23 \text { de } \\
\text { novembro de } 2007 \text {. }\end{array}$ & $\begin{array}{l}\text { Publicação } \\
\text { DOU }\end{array}$ \\
\hline $3 / 2014$ & $\begin{array}{c}\text { Torna pública a adesão dos Estados e do Distrito Federal ao Sistema de } \\
\text { Segurança Alimentar e Nutricional. }\end{array}$ & $\begin{array}{l}\text { Publicação } \\
\text { DOU }\end{array}$ \\
\hline $4 / 2014$ & $\begin{array}{c}\text { Formaliza a adesão do (s) Município (s) ao Sistema de Segurança Alimentar e } \\
\text { Nutricional. }\end{array}$ & $\begin{array}{l}\text { Publicação } \\
\text { DOU }\end{array}$ \\
\hline $5 / 2014$ & $\begin{array}{l}\text { Institui o Comitê Técnico } \mathrm{n}^{\circ} 9 \text { para monitorar, avaliar e divulgar a } \\
\text { implementação dos objetivos e das metas pactuados no I Plano Nacional de } \\
\text { Segurança Alimentar eNutricional (PLANSAN 2012/2015) }\end{array}$ & Documento Técnico \\
\hline
\end{tabular}




\begin{tabular}{|c|c|c|}
\hline $6 / 2014$ & $\begin{array}{c}\text { Institui o Comitê Técnico } \mathrm{n}^{\circ} \\
10 \text { para apoiar e garantir ações voltadas para Povos e Comunidades } \\
\text { Tradicionais, em consonância com o Decreto } \mathrm{n}^{\circ} \text { 6.040/2007, que estabelece a } \\
\text { Política Nacional de Desenvolvimento Sustentável de Povos e Comunidades } \\
\text { Tradicional }\end{array}$ & Documento Técnico \\
\hline $7 / 2014$ & $\begin{array}{l}\text { Institui o Comitê Técnico no } \\
11 \text { para implementar as ações contidas no documento "Estratégia Intersetorial } \\
\text { de Prevenção e Controle da Obesidade: Recomendações para Estados e } \\
\text { munícipios", elaborado no âmbito CAISAN }\end{array}$ & S/informação \\
\hline $8 / 2014$ & $\begin{array}{c}\text { Formaliza a adesão do (s) Município (s) ao Sistema de Segurança Alimentar e } \\
\text { Nutricional. }\end{array}$ & $\begin{array}{l}\text { Publicação } \\
\text { DOU }\end{array}$ \\
\hline $9 / 2014$ & $\begin{array}{l}\text { Aprova as orientações para a elaboração e o monitoramento dos novos planos } \\
\text { de segurança alimentar e nutricional de âmbito nacional, estadual e municipal. }\end{array}$ & Documento de orientação \\
\hline
\end{tabular}

Fonte: Autora baseada nas informações disponíveis no endereço eletrônico http://mds.gov.br/caisan-mds/caisan-nacional/resolucoes 
A leitura flutuante das resoluções buscou encontrar a relação entre suas ementas e demandas das Conferências como forma de identificar o caminho das proposições e sua institucionalização. E permitiu identificar que as escolhas institucionais realizadas são coerentes com as propostas oriundas das Conferências, que mesclam conteúdo de um sistema supra setorial com os modelos de demais sistemas de políticas sociais. Com exceção da definição de sistema fundo a fundo de repasse de recursos, os instrumentos acionados pelo SISAN derivam da construção social das Conferências sendo apreendidas nas Resoluções emitidas pela CAISAN com relação a operacionalização do sistema.

Em 2011, a $4^{\text {a }}$ Conferência optou por emitir uma declaração acerca da manutenção e expansão dos compromissos da agenda de SAN, haja vista a instalação de um novo governo tanto na gestão federal como estadual. Quanto aos aspectos do fortalecimento institucional, reforça o papel do plano de SAN como instrumento de planejamento, gestão e execução da PNSAN e como expressão dos compromissos intersetoriais. Trazem desafios relativos à incorporação de estratégias territoriais na perspectiva da universalização de direitos especialmente para grupos em situação de vulnerabilidade e a urgência na alocação de recursos compatíveis ao cumprimento do Plano.

A novidade do documento, com relação aos anteriores, é o destaque maior feito aos aspectos inerentes a descentralização do SISAN, com a recomendação expressa de um amplo processo de mobilização e de capacitação para disseminar os princípios da Política de SAN para consolidar o SISAN, com estabelecimento de mecanismos de pactuação e financiamento de natureza bi e tripartite. Reforça ainda a necessidade de oito implantar as instâncias estaduais e municipais intersetoriais de SAN e apoio efetivo ao funcionamento dos conselhos locais. Por fim, apresenta a necessidade de financiamento público para fortalecer os CONSEAS no desenvolvimento de sua função de monitoramento, participação e controle social.

Nesse mesmo ano, a CAISAN regulamenta os critérios de adesão de Estados e municípios ao SISAN, reforçando os critérios de criação de conselho, órgão intersetorial e compromisso de elaboração do Plano de SAN e condicionando o repasse de recursos em regime de co-financiamento para gestão do plano e manutenção dos conselhos ao cumprimento das etapas de adesão.

Em 2012, é publicado o Primeiro Plano Nacional de SAN cuja finalidade 
do Plano é promover a segurança alimentar e nutricional priorizando a integração de ações voltadas para a produção, o fortalecimento da agricultura familiar, o abastecimento alimentar e a promoção da alimentação saudável e adequada. Para cada uma d a s

diretrizes básicas, oriundas do Decreto 7.272/10 são estabelecidos objetivos vinculados para cumprimento em 04 anos.

Destaca-se que o objetivo do PLASAN é "a institucionalização do SISAN e seus mecanismos de gestão, participação e controle social, garantindo a sua consolidação, o seu financiamento e a estruturação da capacidade institucional de planejamento, execução e monitoramento da Política Nacional de Segurança Alimentar e Nutricional para, por meio do Plano Nacional e dos Planos Estaduais e Municipais de Segurança Alimentar e Nutricional, realizar o Direito Humano à Alimentação Adequada (DHAA) no âmbito nacional e internacional" (CAISAN, 2012 pg.44).

O PLANSAN aborda a questão do financiamento ao reconhecer a imediata necessidade dos instrumentos de financiamento:

Nesse sentido, um dos grandes desafios a ser enfrentado é a instituição e a implementação de mecanismos e de instrumentos de financiamento e co-financiamento para a descentralização de recursos para gestão do sistema e para a execução de ações intersetoriais de segurança alimentar e nutricional de forma direta e continuada. (BRASIL/PLANSAN,2012; p. 44)

No entanto, seguindo a tendência dos documentos anteriores, o plano deixa de fora definições acerca da origem de recursos, modelo de financiamento e responsabilidades dos entes federados. Fato que é reconhecido pelo próprio MDS, ao publicar o Primeiro Balanço do PLANSAN, atestando a necessidade de se avançar nas discussões acerca do financiamento (BRASIL, 2012).

Quanto ao orçamento, destaca sua integração com o PPA, como resultado da intersetorialidade produzida pela CAISAN:

Uma importante inovação do Plano é seu embasamento nas metas e objetivos do novo Plano Plurianual (PPA) para o período de 2012 a 2015, fato que traz para a esfera estratégica do planejamento da ação pública a tão procurada intersetorialidade, além de garantir plenas condições para sua implementação. (BRASIL/PLANSAN, 2012; p.9)

Registra-se que o governo lançou na mesma época o Plano Brasil sem Miséria, cujos eixos de acesso aos serviços, garantia de renda e inclusão produtiva focam 
diretamente a retira de famílias da pobreza, os dois planos incorporam as mesmas dimensões orçamentárias no que se refere a transferência de renda. 
A questão orçamentária do ponto de vista de arranjo institucional de viabilização do SISAN é um aspecto a ser explorado pela visão dos atores. Na literatura consultada, há referências que apontam que a simples construção compartilhada de uma peça orçamentaria, embora figure como instrumento de planejamento capaz de ter seus resultados posteriormente aferidos não responde pelo esforço de coordenação e de articulação do sistema, podendo seus êxitos e fracassos atribuídos a causalidades múltiplas.

Dos diversos documentos produzidos pelo governo federal nessa área reunindo programas federais em torno de objetivos próximos, mas diferentes, há que se observar que no âmbito local, a oferta de serviços ou programas é a mesma, com instancias de coordenação ou vinculações diversas, o que no caso analisado aqui representa um desafio ainda maior na consolidação do SISAN como sistema nacional.

Embora o plano represente um esforço de avançar na disseminação do SISAN, a ausência de instrumentos de gestão fragiliza a implementação de políticas públicas e nesse caso aprofunda a divisão entre um sistema fundamentado em ideias e intenções e um sistema de gestão da política de SAN. Como consequência, há que se analisar possíveis frustrações com relação à capacidade do governo em ecoar as demandas da sociedade civil frente à agenda de SAN, construída ao longo dos sete anos anteriores ao plano.

Não obstante, o presente estudo tenha adotado a temporalidade circunscrita ao período de 2004 a 2014, optou-se por incluir a declaração emitida na última conferência realizada em 2015, como modo de comunicar o contexto político brasileiro marcado pela reeleição do Presidente da República, com forte crítica da oposição e de movimentos conservadores.

A declaração opta por registrar as importantes conquistas feitas pela SAN nos últimos 12 anos, destacando a saída do país do Mapa Mundial da Fome ${ }^{\mathrm{i}}$ publicado pela FAO, devido à adoção de programas de soberania alimentar e promoção do DHA. Destaca o CONSEA como expressão da participação social e lócus da construção da Política e do Sistema de SAN. E a necessidade de efetivar a participação social como caminho para consolidação do SISAN superando a fragilidade institucional e política dos conselhos, e de fortalecer os espaços de gestão intersetorial para articulação entre os sistemas e programas governamentais, dotando-os de orçamento específico e mecanismos de financiamento. 
A declaração revela, intrinsecamente, uma preocupação com os rumos do SISAN, dado o contexto político que aponta para a possibilidade de um impeachment do Presidente da República, que em caso de concretização é percebido por muitos apoiadores da agenda de SAN, como um recuo nas conquistas sociais realizadas nos últimos anos. A evolução temática e a síntese das ideias presentes nos documentos das Conferências encontram-se sistematizados no Quadro 09 e 10. 
Quadro 09 - Evolução temática, ideias, conceitos e categorias dos documentos das Conferências Nacionais de SAN - 2004-2015.

\begin{tabular}{|c|c|c|c|c|}
\hline & 2004 & 2007 & 2011 & 2015 \\
\hline & $2^{a}$ CNASAN & $3^{\text {a }}$ CNSAN & $4^{\mathrm{a} C N S A N}$ & $5^{\text {a }}$ CNSAN \\
\hline TEMAS & $\begin{array}{l}\text { Construção da Política } \\
\text { com temas diversos e } \\
\text { abrangentes }\end{array}$ & $\begin{array}{l}\text { SAN nas Estratégias de } \\
\text { desenvolvimento }\end{array}$ & $\begin{array}{l}\text { Avanços, ameaças e } \\
\text { perspectivas para a } \\
\text { efetivação do direito humano } \\
\text { à alimentação adequada e } \\
\text { saudável e da soberania } \\
\text { alimentar }\end{array}$ & $\begin{array}{l}\text { Comida de verdade: avanços e } \\
\text { obstáculos para a conquista da } \\
\text { alimentação adequada e saudável e } \\
\text { da soberania alimentar }\end{array}$ \\
\hline CONTEXTOS & $\begin{array}{lll}\text { Propostas para } & \text { o } \\
\text { arcabouço legal e } & \text { e } \\
\text { institucional para SAN }\end{array}$ & $\begin{array}{l}1^{\circ} \text { ano da Lei } 11.246 \text { de } \\
2006 . \\
\text { Construção da política e } \\
\text { sedimentação do SISAN } \\
\text { Exportação do modelo de } \\
\text { SAN. }\end{array}$ & $\begin{array}{l}1^{\circ} \text { ano do Decreto } \\
7272 / 2010 . \text { Implantação e } \\
\text { descentralização da política e } \\
\text { do SISAN Dimensão } \\
\text { internacional }\end{array}$ & $\begin{array}{l}\text { Balanço das ações/ Reforço a noção } \\
\text { da comida como cultura vinda da } \\
\text { agricultura. Cenários locais e } \\
\text { globais divergentes à SAN. } \\
\text { Dimensão internacional }\end{array}$ \\
\hline
\end{tabular}




\begin{tabular}{|l|l|l|l|l|}
\hline CATEGORIAS & Direito, Articulação, & Desenvolvimento, & Acesso, Operacionalização & Alimentação como patrimônio, \\
CHAVES & Diversidade, & Capacidade do Estado, & do Direito, & Cultura, Diversidade como saúde e \\
& Sustentabilidade dos & Direito, redução da & Etnodesenvolvimento, & Sustentabilidade ambiental, \\
& programas, Soberania, & pobreza, Soberania, & Autonomia e & Soberania, Fortalecimento do Estado \\
& Promoção da Saúde, & Institucionalidade, & Autodeterminação dos & como regulador. \\
& Acesso, Equidade. & participação e & povos, Monitoramento, & \\
& & Intersetorialidade. & Pactuação e Adesão. & \\
\hline
\end{tabular}

Fonte: Autora. 
Quadro 10 - Detalhamento das Ideias e Síntese das Categoriais e conceitos analisados a partir das Conferências Nacionais de SAN 2004-2015

\begin{tabular}{|c|c|c|c|c|}
\hline CATEGORIAS INICIAIS & $\begin{array}{r}\text { CATEGORIAS } \\
\text { SUBJACENTES }\end{array}$ & $\begin{array}{c}\text { SUB } \\
\text { CATEGORIAIS }\end{array}$ & CONCEITOS NORTEADORES & INDICADOR \\
\hline $\begin{array}{c}\text { Saúde, Renda, Ambiente, } \\
\text { Agricultura, Cultura, } \\
\text { Abastecimento, Acesso a Agua, } \\
\text { Acesso aos alimentos, Escolhas } \\
\text { Saudáveis. }\end{array}$ & $\begin{array}{c}\text { Determinantes e } \\
\text { Condicionantes } \\
\text { sociais }\end{array}$ & Condição de Vida & $\begin{array}{l}\text { Características sociais da vida. } \\
\text { Diferenças sistemáticas destas } \\
\text { caraterísticas podem causar } \\
\text { desigualdade }\end{array}$ & $\begin{array}{l}\text { Acesso à Saúde, } \\
\text { Acesso a Terra, } \\
\text { Acesso à Renda, } \\
\text { Acesso à Cultura. }\end{array}$ \\
\hline $\begin{array}{c}\text { Direito, Sustentabilidade, } \\
\text { Soberania e autonomia, } \\
\text { Equidade, Redução de } \\
\text { Desigualdade, Capacidade do } \\
\text { Estado em intervir. }\end{array}$ & $\begin{array}{c}\text { Modelo de } \\
\text { Desenvolvimento }\end{array}$ & Visões de Mundo & $\begin{array}{c}\text { Desenvolvimento via atuação do } \\
\text { governo e conciliando } \\
\text { desenvolvimento com preservação } \\
\text { e instituição e efetivação dos } \\
\text { direitos sociais }\end{array}$ & $\begin{array}{c}\text { Capacidade do Estado, } \\
\text { Soberania, Direito, } \\
\text { modelo de produção } \\
\text { Sustentabilidade }\end{array}$ \\
\hline $\begin{array}{c}\text { Articulação, } \\
\text { Intersetorialidade, Gestão } \\
\text { compartilhada, Orçamento } \\
\text { adequado, Participação social, } \\
\text { Pactuação e Monitoramento e } \\
\text { Controle. }\end{array}$ & $\begin{array}{l}\text { Institucionalidade } \\
\text { Sistêmica. }\end{array}$ & Rede e Governança & $\begin{array}{l}\text { Institucionalidade democrática } \\
\text { plena, vazada pela sociedade, com } \\
\text { reconhecimento de direitos, } \\
\text { definição de prioridades, respeito } \\
\text { histórico, pacto e controle social } \\
\text { gestão em rede horizontal. }\end{array}$ & $\begin{array}{c}\text { Articulação, } \\
\text { Intersetorialidade, } \\
\text { Participação, } \\
\text { Monitoramento, Adesão } \\
\text { Pactuação. }\end{array}$ \\
\hline
\end{tabular}

Fonte: Autora 


\subsection{Organização das Entrevistas}

Diante do cenário investigadoe para complementar o levantamento bibliográfico e a análise de documentos, buscou-se por meio de entrevistas com roteiro semiestruturado captar a visão de atores previamente selecionados acerca da organização e implementação do SISAN, conforme resultados da pesquisa documental estabeleceu-se as categorias que fariam parte no instrumento de coleta de dados. Registra-se que as entrevistas foram realizadas presencialmente e gravadas mediante autorização dos entrevistados. Partindo-se de uma visão retrospectiva acerca dos processos que orientaram o SISAN no período abordado, as entrevistas aconteceram no período de fevereiro a abril de 2016.

Entrevistas semiestruturadas são caracterizadas por estabelecer uma direção geral para a conversa, tendo como um dos pontos fortes, a flexibilidade (BABBIE, 2001). Assim, a entrevista teve como objetivo identificar a viabilidade institucional do SISAN a partir do cumprimento ou não de seus princípios e diretrizes na visão dos entrevistados.

Foram selecionados 08 informantes chave escolhidos entre representantes do governo e sociedade com atuação nos quadros da SAN. Entre os representantes da sociedade civil, foi possível contar com a participação de dois ex-presidentes do CONSEA. Nem todos os informantes-chave puderam ser entrevistados, por motivos diversos como conflitos de agenda e ausência de resposta aos contatos realizados.

Quadro 11 - Relação de Informantes por nível de gestão e representação de governo e sociedade civil. Brasil, 2016.

\begin{tabular}{|c|c|c|c|}
\hline INFORMANTE & NIVEL DE GEST & & REPRESENTAÇÃO \\
\hline Número 1 & $\begin{array}{l}\text { Conselheiro } \\
\text { Integrante do } \\
\text { executivo } \\
\text { CAISAN }\end{array}$ & $\begin{array}{c}\text { e } \\
\text { Pleno } \\
\text { da }\end{array}$ & Governo \\
\hline Número 2 & $\begin{array}{l}\text { Integrante do } \\
\text { executivo } \\
\text { CAISAN }\end{array}$ & $\begin{array}{r}\text { pleno } \\
\text { da }\end{array}$ & Governo \\
\hline Número 3 & $\begin{array}{l}\text { Integrante do } \\
\text { executivo } \\
\text { CAISAN }\end{array}$ & $\begin{array}{r}\text { pleno } \\
\text { da }\end{array}$ & Governo \\
\hline
\end{tabular}




\begin{tabular}{l|l|l} 
Número 4 & $\begin{array}{l}\text { Conselheiro } \\
\text { CONSEA }\end{array}$ & Sociedade civil \\
Número 5 & Conselheiro & Sociedade civil \\
CONSEA & Sociedade civil \\
Número 6 & $\begin{array}{l}\text { Conselheiro } \\
\text { CONSEA }\end{array}$ & \\
Número 7 & Conselheiro & Sociedade civil \\
CONSEA & Governo \\
Número 8 & Integrante & \\
\hline
\end{tabular}

Fonte: Autora

Foi realizada uma leitura comparativa entre as entrevistas buscando destacar dados comuns e também elementos diferenciadores, na perspectiva de consolidarem valores acerca do modelo de sistema de gestão adotado para a SAN. As categorias definidas a priori foram historicidade, institucionalidade, intersetorialidade e participação.

Assim, as questões relacionadas ao contexto histórico da agenda, da coordenação, articulação e implementação são recolocados com a intenção de se refletir sobre o futuro do SISAN.

As categorias de analise foram definidas como unidades de registro a priori e foram guiadas pelo instrumento semi-estruturado construído a partir da revisão de literatura e da pesquisa documental. As unidades de contexto são os parágrafos ou extratos das falas que se colocam como unidades de compreensão para análise. Como categorias foram identificadas: a origem da agenda, a construção do SISAN, o sistema de valores o modelo de institucionalidade, e o curso de implantação. As imagens refletidas sobre o cenário do SISAN foram captadas durante as entrevistas por intermédio do seguinte esquema: virtuosidade, enfrentamento, expectativa, risco e reflexidade. 


\subsection{A Construção do SISAN - Virtudes e Fragilidades da Participação Social e da Articulação}

Sobre a origem da SAN como movimento de conquista da sociedade brasileira, um dos entrevistados enfatiza a importância da transposição da agenda da reforma agraria para a agenda da segurança alimentar feita pelo Betinho, com a criação da Ação da Cidadania na década de 90, em um país que já se encontrava eminentemente urbano. Esse resgate da pauta d a reforma agrária na agenda da SAN representa uma aglutinação de forças democráticas dispersadas no período de ditatura militar vivido no país. Para o entrevistado, a SAN é indissociável do processo de defesa da democracia.

É interessante ver..........quando você pega os primeiros documentos do IBASE, do Betinho, no retorno dele, depois que ele volta, o ..........eles estão muito centrados na reforma agrária ainda, é interessante. E ele lentamente vai fazer essa transição, ele percebe, não é? Que lógico, a reforma agrária, para um país que majoritariamente urbano, enfim, não é mais bandeira, não é? A bandeira á a segurança alimentar, não é?

Eu acho que foi uma grande percepção dele, não é?

Porque segurança alimentar no Brasil é muito mais do que segurança alimentar, não é? Toda a luta pela redemocratização ela passa por aí, não é?

Essa conexão entre o contexto dos anos 93-94 e o período recente, recupera a narrativa da origem da SAN enquanto ação pública. É precisamente quando toma posse um vice-presidente que incorpora a agenda da segurança alimentar, oriunda do documento de ações e diretrizes de combate a fome elaborado pelo Partido dos Trabalhadores, que se instala o primeiro CONSEA como um modelo inovador de parceria entre governo e sociedade. Embora nesse intervalo, várias forças da sociedade civil, militantes partidários ou não, tenham mantido viva as demandas em torno da erradicação da fome, é na posse do governo do Partido dos Trabalhadores, que se recompõem as forças políticas que irão conduzir a institucionalidade daSAN.

O sentido de construção social está presente na fala dos atores evocando a importância da origem e os caminhos seguidos pela PNSAN, em contextos 
políticos favoráveis a agenda. Ora valorizando a construção do sistema, via participação da 
sociedade civil, ora destacando programas condutores da política de SAN nos três níveis de governo, e por fim destacando resultados relevantes.

Primeiro valorizar essa ideia de construção, não é? Porque o caso dessas... Que estão vinculadas a ação pública, uma política pública, elas têm uma história, tem uma.... Elas refletem muito o processo do qual elas se originam.

Mas a ideia e processo e de construção social para mim ele é muito importante para entender a questão da segurança alimentar no Brasil e em qualquer lugar.

Uma característica que eu acho bastante interessante e positiva nessa construção da SISAN e da SAN-Brasil é a origem assim, como ela vem se configurando e vem se colocando. Porque se a gente for olhar tradicionalmente as agendas de políticas sociais, não são todos os temas que tem uma participação tão equilibrada de Estado e sociedade”.

Eu acho que é uma organização virtuosa, não é? Tanto é que os resultados demonstram isso, não é? São muito promissores.

A visão programática do sistema também está presente como elemento de confusão acerca do que é mérito do SISAN, como construção coletiva, e o que marca a atuação de um programa especificam bem-sucedido. Entre os programas mais citados como êxitos do SISAN, estão o PBF, o PNAE e o PAA. Este tópico será abordado adiante, mas na fala de um ator essa questão é posta já de início.

Continuo achando, você tem alguns programas que são à base da construção do sistema, e são eles que são ou não portadores do sistema.

Diferenças de contexto político que marcam a formação da agenda e a implementação atual são observadas por um dos informantes. Se o momento de formação da agenda foi impulsionado por fatores políticos como a eleição de um presidente da República do Partido dos Trabalhadores, um contexto de mudança 
poderia apresentar riscos para a agenda da SAN. 
A forma de construir o sistema, ele tem uma marca muito bacana que é do diálogo, do consenso, coloco entre aspas porque a gente já não está vivendo esse momento tão harmonicamente...E essa construção ela é muito estruturada pelo PT, então o PT saindo do governo, sinceramente é isso, o que é que a gente espera, qual é a minha esperança? A gente tem que espalhar ao máximo o que é isso para a propriedade se apropriar e brigar por isso se ela acabar. A gente não tem garantia nenhuma, o fato de ser uma política de Estado não garante que isso vai ter potencialidade.

Se por um lado, a fala dos atores manifesta a positividade da construção do SISAN, a partir de um forte componente de participação social, há também o reconhecimento de que, quando comparado a outros sistemas, ele emerge no topo da esfera política federal, dificultando sua capilaridade. A falta de materialidade também é percebida como aspecto que impõe desafios ao sistema.

O SUS, ele teve um movimento de construção que eu costumo dizer que foi de baixo para cima, é isso, quando chegou na constituinte você já tinha capilaridade muito isso...A SAN foi o oposto na verdade, o que é que aconteceu, os atores que pautaram o sistema e o tema, eles estavam ali na central. Enfim, começou aqui, começou com essa, o CONSEA é um grande espaço para isso. ',

A SAN então ela é uma construção teórica, ela é, saúde é concreta, saúde você vê, ter médico para me atender e tal. A SAN o que é que caracteriza essa rede de serviços de apoio da SAN?

A ideia de que a construção do sistema depende da relação com os demais sistemas universais de políticas como SUS e SUAS permeia a noção de interdependência do SISAN. Nesse sentido, a necessidade de aprofundar as referências institucionais que consolidem um ambiente propicio a negociação e pactuação de estratégias conjuntas se mostra como dificuldade a ser superada. 
Cada vez fica mais claro para mim que é da impossibilidade de falar do SISAN sem que a gente construa, identifique de forma muito clara onde estão às interconexões com o SUS e com o SUAS. .

Essa questão da interconexão, dos elos entre sistema para mim continua como uma questão que tem uma relevância enorme na construção do sistema”... E isso é difícil, mas isso não é só difícil para o Governo, isso é difícil na sociedade também, porque nós somos uma construção.

Sobre os marcos legais, há o reconhecimento de que a LOSAN consagra no âmbito do sistema jurídico brasileiro o direito humano à alimentação adequada, cujo requisito essencial é a soberania alimentar. Para um dos atores, a lei é um avanço na medida em que toca em questões históricas do país.

... a primeira coisa é a LOSAN, não é? Que é muito arrojada, não é? Falar em soberania alimentar...É um resgate da nossa história.

Ao registrar que, em 2010, o direito à alimentação foi incorporado na CF como direito social, tal percepção preenche-se de significado com a afirmação de Habermas (2003) de que as histórias constitucionais são processos de aprendizados e que direitos tidos como polêmicos, em determinados períodos da história, passam no período seguinte a ser aceitos por todos na arena democrática.

É reconhecido que a trajetória do combate à fome tem seu marco histórico situado na década de 30, com Josué de Castro, o que comprova um atraso de no mínimo 80 anos para que essa luta social esteja representada na constituição do país. Se o Brasil é tido como uma nação com muitas dívidas com a sociedade que o formou, a questão da fome em um país produtor de alimentos é uma delas e que ainda hoje por outras vias, como a da promoção da segurança alimentar e nutricional permanece como se tem demostrado, com demandas não resolvidas.

$\mathrm{Na}$ percepção sobre como o sistema opera a intersetorialidade, as perspectivas dos atores são ricas de significados em função de estágios, instrumentos e lócus diferenciados de onde essa intersetorialidade ocorre.

Para alguns atores, a política de SAN carrega intrinsecamente a noção de 
intersetorialidade, uma vez que a sua construção aponta para a confluência de interesses em objetivos comuns de diversos setores. 
E essa ideia da intersetorialidade foi bastante importante nesse processo e é parte, e ela é uma importante explicação... essa visão intersetorialidade, ela é ao mesmo tempo um fator de riqueza e um fator que coloca pelo menos um desafio importante. Então você ter um enfoque abrangente significa que você está caracterizando a questão da segurança alimentar e nutricional como um fenômeno multidimensional.

Pensar segurança alimentar e nutricional... você tem que pensar ela como se em uma política intersetorial... então pensar tudo isso você tem que ter uma ação articulada de Estado.

Embora o esforço pela criação de instrumentos tenha sido bem-sucedido e incorporado ao SISAN, o desafio de fazer a intersetorialidade acontecer é reconhecido pelos atores.

Para os atores, CONSEA e CAISAN partilham o lócus de intersetorialidade, com missões que se mesclam na tentativa de trazer para o bojo da política, o debate acerca de questões atuais e emergentes de SAN e no intercambio de possibilidades e dificuldades do cenário governamental.

Tem um esforço, é um princípio muito pensado, mas operacionalmente a gente roda, roda, roda, roda, roda, roda loucamente,... Do ponto de vista da preocupação do investimento, da análise, da criação de estratégias, eu diria que (a intersetorialidade) se não for cinco, é uns quatro. Mas cooperativamente muito invisível.

Alguns instrumentos que foram instituídos na política, que de certa forma contribui ou ajudam essa intersetorialidade, eu acho que a própria questão da CAISAN... Eu acho que a figura da CAISAN como um órgão de articulação, é imprescindível.

... a natureza do CONSEA é o custo da intersetorialidade... essa natureza consultiva dele é o custo da intersetorialidade, por 
quê? Para poder opinar sobre os diferentes setores, incidir sobre as suas ações, vai inocular nelas a uma ótica intersetorial, o CONSEA tem que ter a pretensão de opinar sobre áreas onde existem espaços próprios de participação tão ou mais legítimos quanto o CONSEA.

O caráter consultivo do conselho como escolha institucional reforça a ideia de uma estratégia de influência sobre os demais setores que busca avançar sobre espaços e políticas públicas cujos espaços de pactuação estão consolidados na estrutura de governo.

A opção aparece como decisão racional para favorecer a participação, o fluxo de informações e a interação de agendas políticas. Tal lógica, tem sua explicação na teoria institucional mediante ao modo como as instituições afetam os comportamentos ao oferecerem aos atores uma certeza quanto ao comportamento presente e vindouro de outros atores (HALL E TAYLOR, 2003). Embora esta seja a opção de partida, diferentes contextos políticos podem fragilizar a instituição, necessitando ser revisitada ao longo dos anos como estratégia de poder e de capacidade de encaminhamento de decisões.

Outro aspecto é que nem sempre o diálogo ocorre de maneira harmônica, haja vista a necessidade de superação não só da fragmentação do governo e seus processos e agentes burocráticos, como da sociedade civil que compartimentaliza suas demandas. Em tais situações, a cooperação horizontal exige uma grande capacidade de coordenação intragovernamental, a fim de que a própria política pública não seja colocada em risco. A figura da CAISAN como este espaço de coordenação, é vista como um mecanismo estratégico para que tal coordenação seja exercida, mas ainda frágil na superação das ideias e processos burocráticos que regem os setores.

... Falar de intersetorialidade sempre é muito complicado, principalmente porque cada caixinha, cada órgão tem uma competência específica, e ela tende a colocar as fichas naquela competência específica.

... os desafios são diversos, intersetorialidade é um termo bonito, na prática muita gente tem dificuldade de implementar. 
A lógica do sistema... a grande dificuldade da palavra intersetorialidade é que ela quer romper com isso (fragmentação) ... E isso tem uma tensão interna que é muito 
difícil, porque ela está nos micros processos burocráticos... criar as CAISANs foi uma tentativa de dizer: bom, podemos romper com isso, aí não adianta, os outros processos todos continuam trabalhando em cima do eu, eu, eu. Então isso é uma coisa que dificulta muito o arranjo do ponto de vista cooperativo".

Para um dos atores, a dificuldade está nas questões de poder que envolvem a intersetorialidade. Segundo Marques (1998), lutas por hegemonia estão presentes no interior dos setores, e vão além do exercício do poder propriamente dito, alcançado a disputa por referenciais, que conjugam ideias e representações sobre o setor, seu objeto e sobre a sociedade.

... a intersetorialidade é uma construção permanente... ela envolve questões de compreensão e questão de poder...".

a construção da intersetorialidade depende que os setores queiram fazê-la, e isso mais uma vez é uma questão de convencimento, isso tem que vir com política, não é? Política com 'P'. "Que é você ter uma dinâmica, seja interna ao Governo, seja na relação com a sociedade, que induz a intersetorialidade”.

Essa construção da intersetorialidade se defronta com as questões que eu falei do poder, do poder do conhecimento, o poder das verbas, se defronta com essa tendência a uma intersetorialidade que é própria de cada um.

É evidente o entendimento de que CONSEA e CAISAN são os mecanismos de compartilhamento de referenciais e de consolidação dos caminhos institucionais da SAN, baseados na intersetorialidade e participação. A capacidade de coordenação e de influência sobre os demais setores é um desafio permanente sendo influenciada por fatores políticos externos ao própriosistema.

Silva (2011) destaca que em sistemas presidenciais como o brasileiro, onde as maiorias precisam ser criadas para garantir sustentabilidade política aos governos, o preço a pagar a fragmentação das indicações de cargos públicos. Daí 
que a tarefa de promover a coordenação entre os setores de governo se reveste de maior dificuldade. 
No caso da SAN, a fragmentação não está presente devido unicamente a fragmentação partidária, haja vista que muitos órgãos públicos e setores são comandados pelo mesmo partido. Parece haver ainda um distanciamento entre as ideias presentes nestes setores que necessitam de uma forte argumentação que demostre a necessidade de cooperar o SISAN.

A outra construção de intersetorialidade se faz no interior do Governo, que é a CAISAN, que é muito parecida no sentido de depender do convencimento dos colegas Gestores". "Para que venham, submetam o seu programa ao plano, permitam que se debatam suas metas, os seus procedimentos, prioridades e instrumentos, dentro de uma concepção mais geral, isso é uma condição, não é simples não.

Para um dos atores, a palavra usada é transetorialidade, a qual associa a representatividade e a capacidade democrática dos espaços de diálogo relacionados a SAN.

Segundo autores como Junqueira (2000) e Ornelas e Teixeira (2015) a concepção de transetorialidade relaciona-se menos aos setores e mais as interações ativas que os articula. A interação se dá em torno da identidade do projeto a partir do qual a rede de atores troca saberes, experiências e concepções.

Aqui, a partir de uma visão de processo democrático de longo prazo, há o reconhecimento de que a virtuose da SAN está na capacidade de interação mais do que de decisão e ou encaminhamento de proposições.

... a noção de transetorialidade foi mantida... E acho que esse é o grande trunfo. Da política de segurança alimentar $e$ nutricional no Brasil. Eu acho que enfim... esse modelo, é que é o modelo na verdade.

O CONSEA hoje é o Conselho, digamos, talvez o mais democrático aí da República. O Comitê de Segurança Alimentar Mundial, ele é um carbono do CONSEA Segundo o Ban Ki-moon é a instância mais democrática do sistema das Nações Unidas... então, eu acho que realmente, quer dizer, é o tema da transetorialidade, ele é fundamental.... 
Outro aspecto é a intersetorialidade na perspectiva da sociedade. O Decreto $\mathrm{n}^{\circ} 7$. 272/2010 estabelece regras para adesão das entidades sem fins lucrativos, como a assinatura de um termo de participação, e remete à CAISAN a regulamentação da participação das entidades privadas com fins lucrativos no SISAN.

Neste sentido, a preocupação com a definição de um código de ética para as entidades privadas que queiram participar do SISAN e com a Lei $\mathrm{n}^{\circ} 13.019$, de 01 de agosto de 2014 que modifica as relações do poder público com as organizações da sociedade civil, se faz presente na fala de um dos atores, mostrando a necessidade de avançar nesses temas, que ainda se encontram pouco explorados na agenda de SAN.

Esta (adesão das entidades privadas com fins lucrativos) é uma questão que diz respeito à intersetorialidade, como lidar, como avançar nesta formulação de um código de ética e tal, para definir aquilo que o Decreto diz.

E em relação as não governamentais... vivemos uma situação... de transitoriedade, vamos ver onde vamos chegar. Porque desde 2003 a Associação Brasileira de ONGs, a ABONG, é onde estão filiadas muitas ONGs, e também com vários movimentos sociais... formou aí uma plataforma para negociar, apresentar uma proposta para o Governo para ser levada ao Congresso, que era um novo marco.

Para Marques (2013, p.80) a governança pode ser assim caracterizada como “ um conjunto de atores estatais e não estatais interconectados por ligações formais e informais operando no processo de fazer políticas e inseridos em cenários institucionais específicos".

Adotando este entendimento, a criação do SISAN traz na origem uma preocupação manifesta com a perspectiva de constituir uma governança em SAN, seja pelos mecanismos previstos seja pela perspectiva futura de normas e regulamentos que possam transformar as formas de organização do Estado e das suas relações de poder com atores do mercado e da sociedade. Nesse sentido, a complexidade de sua implementação decorre dos desafios enfrentados pelo próprio Estado brasileiro que se caracteriza por um ambiente institucional complexo que 
conjuga múltiplos atores, processos, pontos de veto, fragmentação e interdependência. 
Segundo um dos entrevistados, o modelo institucional de SAN, e especialmente o CONSEA inspiraram a reforma do Comitê de Segurança Alimentar da FAO, pela diversidade de sua representação, sinalizando um novo modelo de governança global para SAN. É bom registrar que a frente da FAO está o brasileiro Jose Graziano, um dos responsáveis pela plataforma do Fome Zero e posteriormente ministro do extinto MESA. Embora o sistema das Nações Unidas não possa ser comparado a Estados-nação, talvez seja um dos pontos a ser explicado futuramente se o SISAN foi inspirado em um modelo de governança global que na transposição para uma política pública e com coordenação central que precisa produzir regras, leis e normas obrigatórias enfrenta maior dificuldade de avançar.

Assim como a intersetorialidade, a participação social está atrelada à própria institucionalidade da política. O princípio de participação social é avaliado positivamente no SISAN, e também em alguns programas específicos que se integram a ele. Em sua maioria, os atores consideram que esse processo garante diversidade e numa perspectiva de equidade leva a política para quem mais precisa.

...participação social é um ponto alto, mesmo com as críticas que às vezes a gente tem, mas quando eu penso a participação social eu estou pensando no CONSEA... CONSEAs estaduais, mas também eu estou pensando nos Conselhos Consultivos dos programas, do PNAE, do PAA. Que mesmo com algumas dificuldades, às vezes não têm muita regularidade, etc., mas esse formato é um formato que a gente precisa reconhecer a positividade deles.

$\mathrm{Na}$ nossa constituição brasileira (governos) não são o brigados a passar pelo CONSEAS, é preciso que eles queiram. Por isso é que a participação social é muito importante, porque a participação social no CONSEAS vem sendo feita há anos.

O CONSEA... dos Conselhos que acompanho, é dos mais organizados, mais bem estruturados, com uma maturidade já de participação social muito grande... ele consegue cumprir 
esse papel, de ter representantes, das mais diversas áreas da sociedade, têm representantes de academia, representantes de quilombolas, representantes de povos e comunidades tradicionais, enfim. Pessoas militantes pela segurança alimentar e nutricional, que externalizam naquele espaço as suas demandas, as suas aflições...

Eu vejo a participação muito forte nos atores representantes de públicos específicos, já que são pessoas que carecem muito dessa política, então é muito comum você vê a atuação muito forte dos indígenas, dos quilombolas, dos próprios agricultores familiares, eu acho que tem uma participação relevante....

Este reconhecimento acerca da participação traz um novo dilema que é percebido por um dos atores ao afirmar que a participação da sociedade civil organizada é uma realidade no SISAN. Para ele, um novo estágio se fará com a capacidade do sistema de avançar em direção a demais setores sociais que se encontram a margem dos processos de participação afim de que se complete a cidadania. A questão da universalidade transparece aqui deixando em aberto o debate acerca da compreensão que a sociedade faz do conceito de SAN e de um sistema que atenda a todos os brasileiros. No caso brasileiro, Boschetti (2010) afirma que a seguridade social é um sistema híbrido, na medida em que soma direitos dependentes do trabalho, como é o caso da Previdência, com direitos de caráter universal, como a Saúde e ainda direitos seletivos, representados pela Assistência Social.

Ao tentar situar a política de segurança alimentar nutricional como uma dimensão da seguridade social, torna-se relativamente fácil argumentar a favor da lógica de um sistema de direitos, no molde da assistência social, na medida em que seu objetivo é garantia de acesso aos alimentos. A característica universal está presente com a atenção à saúde e oferta de serviços de alimentação e nutrição nas diversas redes hierarquizadas de saúde e se completa com a competência de exercer a regulação sanitária de alimentos no âmbito do SUS. A garantia da alimentação escolar, como atribuição da educação oferece igualmente à saúde a dimensão de 
universalidade.

Os demais setores e demais programas conferem características diversas ao SISAN, integrando o rol de políticas de desenvolvimento e de perfil econômico como é o caso da agricultura e abastecimento ou promovendo o Estado social de garantia de direitos, tal qual assinalado na $\mathrm{CF}$.

Considerando o princípio da universalidade e equidade presente no SISAN e a miríade de políticas e setores com diferentes alcances, os atores chegam a perceber as políticas de SAN mais equânimes do que universais.

Aonde você vê, por exemplo, a inserção dos quilombolas, os indígenas, os povos de terreiro, eu acho que hoje na agenda política do Brasil a SAN é que mais acolhe a dimensão da equidade... eu acho ... agora a universalidade eu acho que não é o foco assim. Eu adoraria que a gente tivesse pautas universais, mas isso está tão fora da agenda brasileira hoje, que eu não sei, eu acho que ela é nula mesmo assim, esse debate não se dá.

Como você tem um recurso pequeno, essa discussão (da universalidade) ela perde o fôlego, porque você tem que priorizar, se você dá para todo mundo, será que você vai deixar dentro os que mais precisam? Então como fazer essa medida quando você tem um recurso pequeno? Essa é o argumento que te retira da universalidade, e a gente em tese aceita, a gente não briga por mais recurso, a gente se acomoda nisso porque entende que você tem que dar prioridade para a assistência. Então tem esses deslocamentos que vão, não é empobrecer, inviabilizando a discussão da universalidade.

A capacidade de conhecer e dar conta da... contemplar a adversidade. Eu acho que isso a gente melhorou muito, a gente não tem uma visão simplista (ininteligível)homogênea, a gente tem avançado muito na direção de programas, isso para mim é uma coisa muito importante. 
A diretriz de equidade por sua vez é apontada como sendo de difícil aplicação na SAN quando se tem grande desigualdade em determinados aspectos estruturantes da vida social.

É, mas eu diria que é difícil falar de equidade, porque como nós temos questões estruturantes que não estão resolvidas, como o acesso a terra. Então eu diria que alguns programas, especialmente os programas... Programa de Transferência de Renda ou de comercialização...sobre a assistência técnica e extensão rural, e segurança alimentar, e agroecologia e tal. Ali você vê, nós conseguimos batalhar por proposta para que exista a assistência técnica... Chamadas públicas de assistência técnica para mulheres, com determinado percentual de recursos para mulheres, isso é falar de equidade, não é”.

Percebe-se que a universalidade é muitas vezes limitada pela falta de recursos e necessidade de priorização de segmentos populacionais específicos e a equidade limitada a programas de acesso a recursos ou alimentos em função da diversidade, mas deixando de fora aspectos estruturantes da SAN como a questão da terra. Esse ponto remete a questão de uma institucionalidade que se forma ao redor dos programas, muito mais do que na configuração de um sistema.

Sobre a capacidade de influenciar a agenda e as decisões no âmbito do CONSEA, é perceptível a preocupação com os ausentes do processo democrático. O dilema da participação que se utiliza de instrumentos representativos para sua realização está na maior capacidade de alguns grupos sobre outros em acessar as instâncias decisórias. Diante de um patamar participativo onde interesses de determinados segmentos foram articulados e inseridos no âmbito do governo observa- se a imagem de que a política de SAN deve alcançar uma nova etapa na construção da cidadania.

Eu diria os setores organizados, da sociedade civil, eles influenciam... O que me parece muito deficiente, é digamos, a participação dos não organizados.... Quer dizer, porque eu acho que toda a cidadania, deveria de alguma forma ter 
condições de trazer, não é? Ainda que não esteja organizado. "Porque você está falando de setores organizados, você já está em outro estágio da política”.

A ideia subjacente alicerça a participação na vocalização de demandas sociais ainda não apreendidas pelo Estado, com a busca de inclusão de novos grupos sociais. Reforça-se o vínculo da SAN, pobreza e desigualdade tendo na esfera federal o protagonismo social para articulação de demandas e soluções.

Por outro lado, as falas convergem no sentido de em apontar os grupos de acadêmicos e especialistas que ao mesmo tempo são reconhecidos como militantes da sociedade civil como aqueles capazes de exercer influência mais direta sob as decisões de governo.

Eu vejo que tem uma força muito grande de pessoas, de pesquisadores das universidades, que tenha uma militância muito forte, pela questão da segurança alimentar $e$ nutricional"

Recuperando o conceito de Haas (1992) sobre comunidade epistêmica, entendido como rede de profissionais que compartilha um projeto de política, baseado em valores comuns, com conhecimento e competência sobre determinado tema, e autoridade para influenciar as políticas públicas de seu domínio, o grupo de influência identificado pelos informantes compõe tal modelo de comunidade e corresponde pela implementação da agenda de SAN.

Destaca-se que, no âmbito das políticas públicas, os atores se alternam em papeis e espaços de fala diferenciados de modo a manter a vitalidade de suas ideias e aumentar o raio de influência no interior de governo e isso é reconhecido por um dos atores como sendo um dos fatores que impulsionaram os marcos institucionais de SAN.

A SAN sempre foi assim, desde o início sempre teve uma conexão meio que estratégica de atores da sociedade e do Estado, que ora estavam na sociedade, ora estavam no Estado, para avançar no marco institucional, Marco Legal.

As críticas quanto à participação por sua vez, revelam um outro lado do 
processo, e o quanto este pode se fragilizar a depender de contextos políticos diferenciados, esvaziando de sentido os instrumentos institucionais de participação institucionalizados.

.. a estratégia é uma estratégia que ela é muito cruel, que é o seguinte, na relação Estado e sociedade. O Estado diz assim: é isso aí olha, sentem aí e discutam, discutam o que é que vocês acham. E aí a gente discute e diz bom, então nós achamos isso, aí o pessoal olha e diz assim: ah legal, e fica por isso mesmo. Assim, não tem uma consequência interna, então acho que um mecanismo de desgaste nessa construção de sistema é a forma com que o CONSEA se relaciona com o Estado e com.... qual é o instrumento que o CONSEA usa para se comunicar oficialmente com o Estado? São as exposições de motivos e as recomendações. Se você fizer um estudo analítico do resultado delas ao longo dos anos, você vai ver que elas foram assim, elas foram gerando menos impacto dentro do governo cada vez mais.

\subsection{A Visão Sobre A Federação}

A redefinição do papel do Estado brasileiro, a partir da $\mathrm{CF}$, incluiu a descentralização como um dos componentes essenciais da gestão democrática das políticas públicas. Assim, a diretriz de descentralização presente no SISAN integra o formato institucional do Estado com a finalidade de promover a implementação de uma gestão descentralizada e participativa nas três esferas de governo.

No entanto, o desenho do SISAN é referenciado como sendo uma construção teórica de um sistema criado no topo do governo, a partir de demandas sociais coletadas em torno de um projeto nacional de combate a fome e melhoria social. Nesse sentido, os entrevistados reconhecem que há muito fazer quanto à apropriação da SAN pelo território.

A execução de políticas sociais, ela demanda descentralização, a política acontece no território, no bairro, no município, não é o Governo Federal daqui que consegue 
fazer a política acontecer. Então é imprescindivel, principalmente os municípios, ter uma capacidade de execução de políticas públicas muito grande... em termos de institucionalização, eu acho que é o desafio do SISAN, ganhar capilaridade...

Agente tem que começar com uma premissa, a institucionalização da segurança alimentar e nutricional como objetivo de política pública, ela ainda é.... Ela ainda tem fragilidades da onde decorrem as dificuldades de você fazer com que os Governos nas várias esferas assumam esse objetivo como orientador da situação".

..o governo conseguiu avançar bem nos Estados, eu acho que município ainda é um desafio grande.... Principalmente no contexto de restrição orçamentária, de recessão econômica, onde você tem dificuldade em patrocinar os municípios, para que ele ganhe a institucionalidade mínima que é necessário para tocar um Plano Nacional de Segurança Alimentar e Nutricional.

Na SAN o que é que aconteceu, o primeiro ator que veio para a construção do sistema não foi o município, foi o Estado. Então a dificuldade de tornar isso concreto ficou muito maior, porque você não partiu do território, você parte de dimensões que vão compor o território lá embaixo... existe uma dificuldade muito grande de integração disso tudo, primeiro porque os municípios são frágeis nisso, então eles acabam às vezes montando ou aderindo ao sistema por pressão do Estado ou porque eles têm algum programa que eles querem aprovar e tem que ter CONSEA, tem que ter CAISAN.

Outra preocupação é o alinhamento da política com os objetivos do governo federal. Como referido anteriormente por um dos entrevistados, a identificação partidária da SAN com o governo do PT, pode ser interpretada como obstáculo 
para que o sistema ganhe dimensão nacional.

A descentralização é mais efetiva quando você tem Governos estaduais que por alguma razão tem mais proximidade com o tema, mais afinidade com o tema e até com o Governo Federal, e que tem sociedade civil organizada no entorno do tema.

Note como foi importante em toda a trajetória até recentemente, a resistência de Governos estaduais ao tema que diziam que era um tema do PT, que era um tema do Lula. A partidarização do Fome Zero, da segurança alimentar, foi importante, ela bloqueou muito processo de descentralização.

A adesão pactuada é percebida como uma estratégia de superação do impasse ocasionado pela forte identidade do sistema com a política partidária, representando o mecanismo indutor do governo federal para alcançar a capilaridade do SISAN. Ao mesmo tempo, tal adesão voluntária gera desigualdades importantes na expansão nacional do sistema, gerando descompassos entre sua lógica de articulação e os programas que dele fazem parte, muitos dos quais de caráter universal:

Então a saída tem sido qual? Instrumentos que o MDS... E a SISAN e a CAISAN vêm desenvolvendo.... Uma razoável dose de êxito na adesão, todos os Estados aderiram algo muito em um crescente do município. Pois então esses pactos, esses termos de adesão, compromissos, vem sendo feitos nessa linha que eu dizia, um pouco dependendo do poder... Do Governo Federal e da demanda social nessas localidades, sejam elas Estados ou municípios. E aí os governantes reagem de uma forma ou de outra, então é uma descentralização muito desigual, ela não é automática, ela é tudo menos automática, mecânica e homogênea. Ela é bastante desigual, muito condicionada por essas dinâmicas de sensibilização política e de participação, e do poder indutor do Governo Federal. 
A afirmação dos atores sobre a logica de financiamento programática e não intersetorial aponta para um descolamento dos programas com o sistema. Ou seja, há um ordenamento programático emanado do governo federal que não garante a unidade nem comando ao SISAN. Nesse sentido, a definição sobre financiamento e sobre as atribuições das esferas de governo são percebidos como aspectos cruciais do processo de descentralização. Assuntos que não foram ainda definidos no âmbito das esferas decisórias do SISAN:

É imprescindivel, principalmente os municípios, ter uma capacidade de execução de políticas pública.... E o Governo Federal ele faz isso através de descentralização de recursos, não é? Então você tem o PAA que é um exemplo, você tem cisternas que é outro, que você faz ouvir entidades federados, você faz com a sociedade civil organizar ... e ele tem realizado isso, que a descentralização de recursos públicos para esses diversos entidades. Agora, em termos de institucionalização, eu acho que é o desafio do SISAN, ganhar capilaridade...

Os programas... os seus recursos e tal, com suas redes, mas essa ainda é uma... Dificuldade é como no nível local, eu saio da lógica programática, para nova lógica intersetorial.

Não tem lei que diz até quanto você deve gastar no mínimo, e assim por diante, não está escrito em lugar nenhum que... Ou não estava que os Governos têm que promover segurança alimentar e nutricional. E a fragilidade dela é tamanha que a própria constituição, você se lembra disso, não incluía a alimentação entre os direitos sociais. Então essa é uma fragilidade que ela vem sendo enfrentada no Brasil passo a passo....

... a gente tem um desafio grande para construir no SISAN, ou seja, qual é o papel da União, qual é o papel dos Estados, e qual é o papel dos municípios? Qual são os grandes compromissos que eles têm nos próximos anos? Então eu 
acho que uma das questões é cravar responsabilidades nas diversas entidades.

Outro movimento da descentralização representado pela capacidade de Estados e municípios protagonizarem ações é levantado por um dos entrevistados, como um dos gargalos da gestão da SISAN. No entanto, parece pertinente questionar a compreensão do conceito e do sistema pelos entes municipais.

Se o papel indutor do governo federal se encontra fragilizado, pela incerteza do conteúdo da política que será descentralizada, indefinição acerca das atribuições de cada uma das esferas e dúvida quanto às responsabilidades financeiras, parece que a possibilidade de protagonismo também adote uma lógica programática e não sistêmica.

Esse fluxo vai à construção, devagar, pelo seguinte: Às vezes chama a minha atenção a dificuldade que tem Estados $e$ municípios de pensar iniciativas que estão no âmbito da gestão deles, que eles poderiam tomar...Uma Prefeitura que, por exemplo, cria dificuldades para o funcionamento de uma feira, ela está criando barreiras para a construção desse sistema.

Essa capacidade de tomar iniciativas que sejam no âmbito próprio de municípios e de Estados, eu acho que ainda carece isso no caso brasileiro.

A descentralização vai ocorrer a meu ver, de fato quando nós tivemos Governos estaduais e municipais com iniciativa, que não fiquem exclusivamente na dependência do Governo Federal. Muitas vezes a universalidade, a universalização de políticas, ela não leva em conta tanto as especificidades regionais, de bioma, de tipo de população, nós ainda vivemos esta questão a meuver.

Uma questão também que me preocupa muito e que tem relação com descentralização, que são descontinuidades às vezes. Tem programas que ou que sofrem interrupção, ou que 
tem tal redução de recursos que tem consequência para a sua própria estruturação ou desestruturação. Vou dar o exemplo em relação PAA, o PAA passou por mudanças, vem passando por mudanças, com novas normativas.

O conflito entre sistemas também aparece quando se fala do conteúdo da política e dos programas que estão sob a égide do SISAN.

Existe uma crítica, por exemplo, dos municípios, que é o seguinte, o SISAN é do MDS, mas uma das principais ações está dentro do SUAS, e aí você não tem uma relação harmônica”

Segundo Palotti (2009; p.93), a ideia de descentralização do Estado se resume a duas dimensões principais, ou seja, para quem e o que se quer descentralizar e complementa: “ a descentralização pode envolver a transferência de competências e atribuições políticas, fiscais e/ou referentes à gestão de políticas públicas".

A transferência de responsabilidades de gestão e implementação de políticas e programas financiados pelo governo federal é caracterizada Almeida (2005) como processo de consolidação de um projeto ou política provocando relações intergovernamentais diferenciadas a depender da autonomia e ou centralidade da tomada de decisões.

Nesse sentido, o SISAN apoiado em programas federais com trajetórias próprias de descentralização, enfrenta dificuldades ainda maiores no percurso em busca de capilaridade nacional. A indefinição sobre o que está sendo descentralizado e para quem, na medida em que a coordenação local está dispersa entre vários setores, pode ser uma das causas do desinteresse dos gestores locais, que encontram suas demandas atendidas unicamente com as entregas feitas pelos programas federais associados a SAN. O debate aprofundado deixando de lado arestas partidárias pode contribuir para redefinir a estatura do sistema e reposicionar sua trajetória.

\subsection{Questões sobre Gestão, Orçamento e Financiamento}

É bem conhecida a relação entre o orçamento público e a tomada de decisão 
em políticas públicas. Segundo Abreu e Câmara (2015) o orçamento é elemento estruturante da ação governamental, sendo considerado um primeiro filtro da viabilidade política e econômica das políticas públicas.

Sendo o orçamento um instrumento da ação pública e no caso da SAN sua articulação com a gestão é vista como uma das diretrizes de organização do sistema, a percepção dos entrevistados de que como esse arranjo se revela indica numa primeira análise quais são as apostas do SISAN com relação aos resultados que pretende alcançar.

Mais uma vez a abrangência do SISAN impõe desafios na análise da relação entre orçamento e gestão das políticas. Na fala de um dos entrevistados, o assunto é tido como delicado uma vez que pode levar a diferentes interpretações acerca do sucesso ou insucesso da política.

Primeiro a gente tem que falar de qual SAN que a gente está se referindo. Porque se eu parto do pressuposto que a SAN é um eixo de desenvolvimento social, eu posso pegar toda a agenda, toda a agenda de políticas sociais e dizer: nossa, tem dinheiro do SUS, tem o dinheiro do SUAS, está lindo, mas vamos combinar que não é essa a SAN real, as pessoas que estão ali, as ações que estão lá, elas não têm uma articulação com o direito humano e alimentação adequada, ela tem em comum um componente, uma dimensão do conceito que é fundamental, mas aí tem a intencionalidade para aquilo fazer sentido.

Mas aí vamos para critérios para você olhar dentro do PPA. Vamos partir do pressuposto que são setores que estão envolvidos com a construção dessa agenda dentro do CONSEA e da CAISAN. E aí a ação que ganha mais dinheiro é o Bolsa Família”.

Em um estudo sobre a composição do orçamento da PNSAN, Custódio et al. (2013) identifica 814 ações orçamentárias agregadas a 229 programas associados a 22 ministérios principalmente pelos Ministérios de Desenvolvimento Social, Educação, Agricultura e Desenvolvimento Agrário. Segundo as autoras: 
Do volume total de recursos destinados aos 229 programas identificados, mais de $90 \%$ foram destinados a apenas 10 
programas em 2010, sendo o Programa Bolsa Família (PBF) responsável isoladamente por $58,5 \%$ do total nesse ano. (CUSTÓDIO ET AL, 2013; p.146)

É importante gravar que os programas de transferência de renda são reconhecidamente instrumentos de redução e desigualdades e combate a pobreza destinada a contribuir com atendimento das necessidades sociais básicas (Mesquita, 2013). A criação do Programa Bolsa Família, em 2004, surge da fusão de diversos programas de transferência de renda com finalidades distintas como frequência a escola, cumprimento da agenda de saúde materno infantil, cartão alimentação para aquisição de alimentos e outros, na tentativa de superar a fragmentação e dar eficiência aos mesmos em âmbito nacional.

Quando a gente fez o orçamento de segurança alimentar $e$ nutricional, acho que foi em 2005, 2006 que a gente começou o debate, e a gente até ter um plano que tivesse expressão orçamentária, acho que o grande debate é que políticas são segurança alimentar, que políticas não são, das que são ou que estão diretamente ligadas à segurança alimentar, e as que só são indiretamente ligadas.

Tem duas grandes rubricas, no que a gente chama de orçamento de segurança alimentar e nutricional, que elas são bem robustas, que é o Programa do Bolsa Família, e que é o Benefício de Prestação Continuada. E essas são transferências, no caso o BPC Constitucional, no caso do Bolsa Legal, que de certa forma, eles são de grandes vultos. Então hoje o orçamento de segurança alimentar e nutricional deve estar na cada de 70 bi, eu diria que dois terços talvez estejam nessas duas ações. '

Aliar programas de transferência de renda à objetivos de segurança alimentar e nutricional foi elemento estratégico da política social brasileira dos últimos anos na medida em que reuniu uma antiga demanda da sociedade fundamentada no combate à fome com a distribuição de renda monetária, componente essencial da cidadania no modelo capitalista. 
Entre os entrevistados, embora haja o reconhecimento unanime sobre a importância do Programa Bolsa Família, há o entendimento que outros programas cumprem de forma mais direta a integração de ações voltadas à segurança alimentar e nutricional. Entres estes, o Programa de Aquisição de Alimentos e o Programa Nacional de Alimentação Escolar são expressões dos objetivos da PNSAN.

Mas tem outras políticas que eu diria que estão mais diretamente relacionadas à segurança alimentar $e$ nutricional, que também tem a sua expressão, como por exemplo, a questão do Programa de Aquisição de Alimentos, e o Programa de Alimentação Escolar, o PNAE. Então eu acho que esses dois programas também tem uma expressão significativa.

O PAA, mais no sentido de você acho que atua nos dois lados, tanto no sentido de você favorecer o agricultor familiar, ter capacidade de produzir alimentos para si mesmo, como poder comercializar o seu excedente, como uma parte desse alimento que é comercializado, como você pode fazer doações aos públicos mais vulneráveis, tanto atua na oferta como no consumo, não é? O PNAE, como forma de você garantir minimamente que as crianças que frequentam a escola, consigam ter refeição, e consigam ter um desenvolvimento sadio e condizente com o que é necessário para uma boa educação.

.... Depois do Bolsa Família a questão de aquisição de alimentos era uma agenda que mais capitalizava recurso. Hoje eu acho que ele abre para o Bolsa Família, e que eu vou te dizer, ele é importante para a SAN? Ele é fundamental, quer dizer, ele é importante para o país, importante economicamente para o país. Não é necessariamente você garantir renda que você vai fazendo a conta de que você está melhorando a segurança alimentar e nutricional. Tem um longo caminho. E você não tem isso, você não tem esse 
desenho assim. Quando você olha o PPA". 
Cunha (2011) afirma que mesmo que o PPA tenha retomado a questão do planejamento governamental, e venha paulatinamente se aproximado de um formato de plano de desenvolvimento de longo prazo, com a incorporação de dimensões mais estratégicas, o grande número de ações orçamentárias ainda dificulta uma análise de prioridades. Tal assertiva reforça a ideia de que não é possível superestimar a questão orçamentária.

A relação entre orçamento e gestão, primeiro no caso do Brasil ele é muito comandado por uma visão fiscalista oriunda da economia da Fazenda, que fez o Ministério do Planejamento Orçamento e Gestão virar Ministério de Gestão do Orçamento... ter constrangimentos fiscais.

...tentaram melhorar e acho que conseguiram alguma medida, melhorar um pouco o ordenamento das ações, procurando dar a elas uma elegibilidade ...que ficassem mais claras algumas prioridades, e nesse sentido o PPA vem ganhando... o PPA ganhou o significado, ele passou a ter uma função, um papel de indicar, sinalizar prioridades... tem muita dificuldade de rastrear ações.

Então só colocar... a segurança alimentar no orçamento não dá garantia se eu não tiver discursando sobre o financiamento dessas políticas. Então eu acho que eu colocaria como desafio, e mais como dar capilaridade para todo esse sistema....

O orçamento é um problema, porque é como dizem, os Prefeitos falam assim: "Ah, qual é o sentido da gente aderir aos sistemas"? O que a gente ganha com isso?" Acredita que falam assim? Tem Prefeito que fala isso, porque falam: "No caso da saúde tem lá tudo certo, da assistência também, na da segurança alimentar não tem." Precisa definir isso é uma lacuna que eu disse, não é? "“.

A indefinição sobre os mecanismos de financiamento do SISAN se sobrepõe a incorporação de um amplo número de programas no PPA sob a égide da SAN. 
Considerando uma nova etapa da política, uma vez que sua base legal e seu modelo já estão configurados, a questão central parece estar na definição da identidade, na interlocução com gestores municipais e no alcance da capilaridade da política.

\subsection{Decifrando os Significados do Monitoramento}

Ao questionar sobre o monitoramento da situação alimentar, as respostas dos entrevistados se situam em dois tipos de posicionamento. $\mathrm{O}$ primeiro refere-se à própria dificuldade do governo em geral com a temática do monitoramento e avaliação, caracterizando-o como um problema. A outra análise mais positiva parte do esforço em reunir indicadores de diferentes dimensões da situação alimentar e nutricional, e avançar na informação sobre a situação alimentar do país.

Todo o problema de monitoramento no Brasil, é muito frágil ainda... assim, e todo o nosso monitoramento, pelo menos, o nosso caso aqui, eu vejo a dificuldade que a gente tem, é muito centrado em número ainda, pouco centrado em qualidade, na avaliação qualitativa.

Porque realmente falta perna mesmo, acho que para você monitorar de uma forma mais abrangente assim o andamento dos programas. Aí por isso que você encontra distorções, você encontra questões aí graves que a gente sempre vê aí, mas não é por que o programa é ruim, nem nada disso, é por que realmente acho que falta ainda talvez uma maior estruturação do monitoramento por parte do governo.

Monitoramento é uma coisa que a gente tem tido pouco, acho que a gente teve um momento importante de discussão disso há uns quatro, cinco anos atrás. Eu acho que muitas vezes ele está muito mais voltado para o sistema, para as ações, do que para as pessoas, entendeu? E outra coisa assim, isso tem a ver um pouco com o momento político, quando a gente tinha meio que mais prioridade na agenda política e a gente estavam fazendo ações num território arrasado, as respostas eram sempre muito boas. Então interessava monitorar. 
Existe um monitoramento muito mais programático do que da situação de insegurança alimentar, o esforço do MDS está muito em cima da gestão do sistema, então eu tenho o Mapa SAN, a gente ...um diagnóstico dos CONSEAs para entender esse projeto.

O SISVAN, a escala e outros instrumentos de monitoramento que gente (CONSEA) andou criando não... ou é um arsenal, não desprezível, não é? Eu estou pensando... Todos os inquéritos indígenas, os levantamentos específicos com (ininteligível) populacionais, isso avançou muito. Tanto é que a gente hoje é capaz falar das mazelas que persistem na sociedade com muito mais... "...

Eu acho que esse é um ponto alto que eu vejo nos últimos tempos, tanto na reprodução de informações pelo próprio Governo, tem havido um aprimoramento do sistema de informação, e eu estou considerando isso aí lato sensu também como pesquisa.

De acordo com Vaitsman (2009) é possível confundir monitoramento e avaliação e controle. Se o controle se refere ao cumprimento de normas e metas de execução e a avaliação envolve vários aspectos de um programa ou política, como relevância, eficiência, efetividade, resultados e impactos, omonitoramento:

.. Consiste no acompanhamento contínuo e cotidiano, por parte de gestores e gerentes, do desenvolvimento dos programas e das políticas em relação a seus objetivos e metas. É uma função inerente à gestão e à gerência dos programas, devendo ser capaz de prover informações sobre o programa, permitindo a adoção de medidas corretivas para melhorar sua operacionalização. (VAISTMAN, 2009; p.157)

Nesse sentido, a abordagem dos entrevistados refere-se a um ou outro aspecto destes mecanismos para expressar a diretriz de monitoramento da situação alimentar presente no SISAN.

Há por um lado o reconhecimento da melhoria dos sistemas de informação e de 
avanços no levantamento das condições de alimentação de populações específicas. Uma abordagem mais gerencial, no que se refere ao monitoramento, também é percebida em etapas mais recentes, como uma ação positiva. No entanto, apontam-se lacunas acerca de aspectos qualitativos das ações e chama atenção a falta de referência acerca de processos de tomadas de decisão a partir da informação coletada.

Tal constatação coaduna-se com a observação de Abrúcio (2011) sobre a prática do monitoramento, no período da gestão federal petista, que embora marcada pelo uso de instrumentos de avaliação e monitoramento de políticas públicas, não gerou novos modelos de organização para se chegar aos resultados pretendidos.

Tanto a abordagem do monitoramento da situação alimentar de indivíduos e grupos como o monitoramento programático mostram a dificuldade de se alcançar uma medida que aponte para a efetividade do SISAN.

Nessa perspectiva, observa-se a ausência de indicadores que sintetize a SAN em toda sua abrangência, como demonstrativo de um resultado que possa ser relacionado ao SISAN de forma mais direta. Se ter ou não Conselho, ter ou não instancia de governo, ter ou não um plano ou uma lei apontam para a formalização do sistema ainda está longe de indicar uma atuação sistêmica efetiva. E sinaliza para os desafios de uma implementação que mescle iniciativas autônomas dos entes federados e um corpo de serviços prestados pela política de SAN.

\section{8. Uma leitura de conjunto da ópera: considerações acerca dos resultados a partir das categorias}

As categorias analisadas aqui mostram o percurso que vem seguindo a implementação do SISAN, na visão dos informantes selecionados, corroborando com a hipótese inicial deste estudo, acerca das ambiguidades que os mecanismos adotados

oferecem para caracterizar um sistema nacional que leve SAN para todos os brasileiros.

Retirando-se a atuação de programas consagrados, uns há mais de cinquenta anos como o PNAE, outros com mais de uma década como o Bolsa Família, ou aqueles que tem na prestação de serviços de nutrição na atenção básica de saúde, e na assistência social, resta um conjunto de programas localizados e ações pontuais cuja capacidade de sustentação pode oscilar com o tempo e o contexto político do próprio governo federal.

As entrevistas corroboram que a trajetória exitosa dos movimentos de SAN, a 
conquista da agenda governamental, a escolha do modelo de governança e os dilemas de implantação do Sistema alicerçado em programas de diversos setores e a capacidade de coordenação intersetorial, são fatores que são interpretados como forças e fragilidades com que a SAN se coloca no cenário de políticas públicas sociais. 
Com o objetivo de ilustrar a percepção dos informantes sobre como situam a realização das dos princípios e diretrizes do SISAN, foi solicitado que em uma escala de 0 a 5 pontuassem cada uma delas, no momento recente. Os valores pontuados foram somados e retratados pela media, mediana e desvio padrão conferido a cada item analisado.

O sistema recebe uma avaliação positiva e homogênea entre os participantes, sendo os itens referentes a participação social e promoção da intersetorialidade os que alcançam números médios mais altos da escala, repetindo as ideias contidas nas falas captadas. Calculamos o Coeficiente de Variação das notas para verificar, de maneira mais descritiva, a homogeneidade dentre os resultados para cada princípio ou diretriz. A maior variação recai sobre a conjuntura, com um $\mathrm{CV}=45,94 \%$, confirmando uma alta variabilidade nas notas desse quesito. Os outros coeficientes também se mostraram elevados, como os de monitoramento (33,93\%) e participação social $(28,06 \%)$, consolidando os questionamentos acerca do tipo de monitoramento efetuado, conforme levantado durante as entrevistas. A descentralização permanece como tema sensível, que junto com as premissas de articulação entre orçamento e gestão, universalidade e equidade e monitoramento compõe o grupo com pontuação media situado nos menores valores da escala.

Esse gráfico é de natureza ilustrativa, não substitui a análise qualitativa apresentada e busca tão somente captar, após a narrativa dos participantes, a avaliação subjetiva de méritos e dificuldades do conteúdo de orientações que cercam a implementação do SISAN. Foi escolhido o Box-Plot para que fosse possível verificar visualmente a distribuição das notas conferidas pelos entrevistados aos princípios e diretrizes analisados. 
Gráfico 1 - Distribuição das Notas Conferidas aos Princípios e Diretrizes do SISAN

Distribuição das notas conferidas aos

Princípios e Diretrizes do SISAN

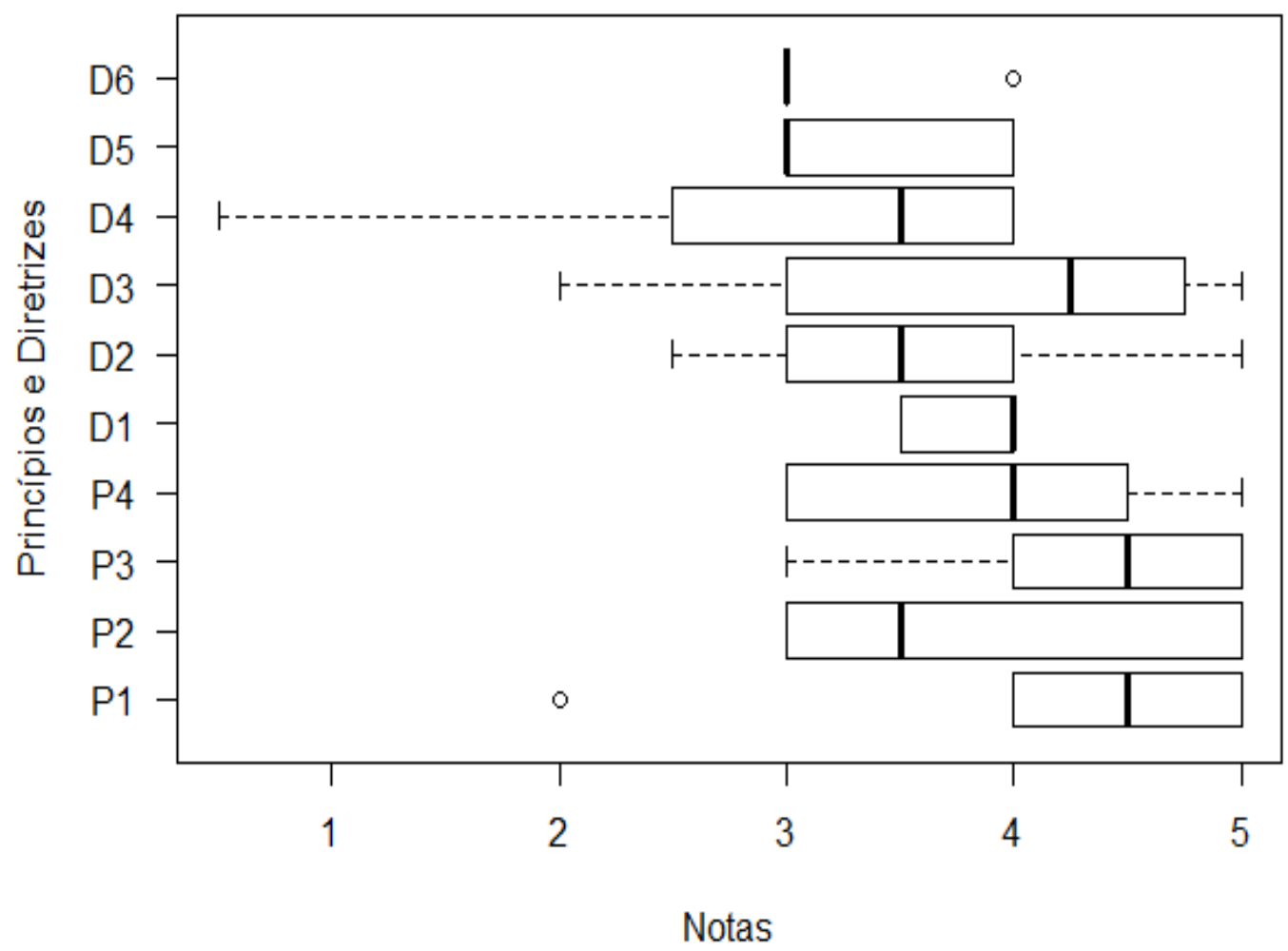

LEGENDA: P1= Participação social; P2= Universalidade e equidade; $\mathrm{P} 3=$ Transparência; $\mathrm{P} 4=$ Autonomia e dignidade; D1= Intersetorialidade; D2=Descentralização; D3=Monitoramento; D4= Medidas conjugadas; D5= Articulação entre orçamento e gestão; D6 =Estimulo à pesquisa e capacitação.

Fonte: a autora a partir dos dados coletados pelas entrevistas. 


\section{Capitulo 5 - Conclusões}

Nesta tese analisou-se o processo de implementação do SISAN investigando sua trajetória, seu percurso institucional e federativo e as ideias que conformaram a política de SAN no Brasil. Buscou-se recuperar antecedentes que em sua perspectiva histórica e com base nos referenciais de análise de políticas públicas e da abordagem neoinstitucional pudessem demostrar que o percurso de implementação do SISAN, diante de seus mecanismos institucionais traz limites a concretização da PNSAN no nível nacional.

A análise foi dirigida por componentes teóricos que procuraram elucidar em um primeiro momento, o que a história trazia de suporte para a construção do SISAN, e os fatos relevantes, que desembocaram na conjugação de forças em torno da agenda de combate à fome e promoção da segurança alimentar e nutricional, e as escolhas institucionais realizadas pelo Estado brasileiro, por meio de levantamento bibliográfico, documental e empírico, este último fundamentado pelas entrevistas com informantes chave que estiveram presentes em momentos crucias da elaboração da política nacional.

De forma geral, as ideias dos atores e das instituições materializadas no conjunto de procedimentos formais adotados, conformaram o arcabouço de análise que teve como unidade de analise o SISAN. De forma complementar, optou-se por uma análise quantitativa dos dados secundários informados por gestores estaduais e municipais reunidos pelo IBGE, a luz dos questionamentos elaborados pela própria coordenação central do SISAN, acerca de sua descentralização.

Ao descrever os antecedentes históricos e trajetória da Política de SAN e do SISAN, segundo revisão narrativa de literatura encontrou-se como resultado o reconhecimento de uma trajetória de lutas sociais vitoriosa que encontrou eco no contexto político partidário vigente, ao assumir projeção na agenda de governo federal pós eleições de 2002. A bibliografia consultada evidencia a construção positiva do SISAN pautada em manter, mesmo em um Estado de configuração adversa, os princípios de desenvolvimento social e de conquista de direitos, reafirmando institucionalmente em seu marco legal, o significado abrangente da segurança alimentar e nutricional. Reforça ainda o potencial dos mecanismos institucionais adotados para a realização do ideário da SAN em seu sentido de promover a participação social e a intersetorialidade como elementos constitutivos do sentido e significado de implantação do SISAN. 
A análise dos dados secundários sobre a disseminação do SISAN no território brasileiro, a partir das informações coletadas pela MUNIC/ESTADIC, cujo objetivo foi apresentar a repercussão da montagem do sistema nos níveis subnacionais, evidenciou as fragilidades que o SISAN enfrenta em adaptar os mecanismos federais de coordenação, articulação, participação e produção de consensos ao nível local, dado aos baixos números obtidos após 10 anos de construção de sua institucionalidade.

A análise de conteúdo das entrevistas realizadas com informantes chaves da política de SAN do governo e da sociedade civil, corroboram o virtuosismo do processo de construção do SISAN, reforçando a escolha consciente dos mecanismos institucionais adotados, mas emitindo mensagens de dúvidas e expectativas acerca de sua implementação diante de um cenário de perda de centralidade da agenda e de dificuldades na superação do modelo fragmentado do Estado brasileiro. A fragilidade dos mecanismos de financiamento do governo federal e ausência de responsabilidades com as ações e financiamentos subnacionais bem como a dificuldade em monitorar os resultados da política foram considerados explicativos dos riscos que o SISAN enfrenta em seu percurso como política pública nacional.

Com um percurso histórico rico em lutas sociais e de forte construção teórica, a questão da alimentação e seus entornos marcados pela contradição do modelo de desigualdade que afeta a democracia do Estado e da sociedade brasileira, chega ao século 21 repleta de esperanças de se ver como agenda política prioritária de um governo pautado pelo fortalecimento de direitos e maior igualdade social.

Se o modelo construído valorizou o percurso histórico trazido pela sociedade, cujos atores sociais não se abstiveram de trazer à tona, seja comunitária, política, ou academicamente as mazelas brasileiras com relação a fome e a falta de acesso adequado aos alimentos como questão social que impedia o pais de seguir adiante no seu processo de desenvolvimento, esta tese baseada na profícua produção cientifica do pais nesse tema aponta positivamente para o êxito alcançado.

Valores democráticos de participação social, cooperação institucional e construção de uma intersetorialidade não competitiva, mas sim solidária permearam a formulação do conceito, do sistema e da política de SAN. Tais valores corroboraram o papel central que o Conselho criado em prol da garantia do direito humano à alimentação desempenha na institucionalidade do SISAN sendo 
reconhecidamente um dos mais representativos e tecnicamente capaz de formular orientações e políticas de interesse do campo da SAN 
Do ponto de vista acadêmico, as análises não são menos eloquentes, a produção cientifica consultada aporta experiências e evidencias acerca das soluções que são assumidas como estratégias e políticas de governo, ressaltando o caráter inovador dos arranjos institucionais que se moldaram pela busca da participação e da articulação entre os diferentes setores voltando-se à criação de possibilidades para influenciar a dinâmica de governo em sua perspectiva democrática.

Com tal somatório de forças sociais e cientificas foi tarefa desafiadora discorrer sobre o fato de que implementação do SISAN sofre de várias limitações e pontos críticos que colocam em risco o seu alcance da forma abrangente como afirmada conceitualmente. Se a erradicação da fome é uma realidade, possibilitada por um dos maiores e mais representativos programas de transferência de renda operado por um governo, como é o caso do Programa Bolsa Família, como atestam os achados da revisão narrativa e integrativa de literatura e as falas recorrentes dos entrevistados acerca da virtuosidade do SISAN, na garantia do acesso aos alimentos, ele é insuficiente para afirmar que alcançamos como pais, a segurança alimentar e nutricional.

E é nesse ponto, que esta tese pretende contribuir para o debate acerca da implementação de políticas, que com forte apelo popular traduzem anseios e projetam ideias para o social que culminam na sua adoção como elemento essencial de um modelo de governo. A agenda de combate à fome aliada aos sentidos conferidos pelo conceito de SAN assumiu esta posição que a permitiu construir uma institucionalidade própria e seguir adiante enfrentando os desafios que a organização e o modelo do Estado brasileiro colocam.

Uma das primeiras ideias identificadas refere-se à positividade que cerca a construção do SISAN e seu êxito na ocupação da agenda governamental. Contribuíram para esta percepção aspectos temporais, de organização social, de capacidade de resposta aos problemas da fome e aspectos essencialmente políticos, uma vez que foi diante da oportunidade aberta com a transição de governo federal no ano de 2003, que a SAN marcou o programa e a agenda do governo eleito, dando início ao seu processo de institucionalização fundada nas expectativas de ampla participação social e de esforço para a articulação intersetorial.

Ao analisar os interesses dos atores e a percepção da influência que estes exerceram sobre a agenda da SAN, foi observado duas temporalidades. A primeira decorrente do forte poder exercido pelo grupo de atores responsáveis pelo Projeto 
Fome Zero advindo do Instituto da Cidadania, que por sua proximidade com o então 
Presidente Lula, torna o projeto o núcleo do discurso eleitoral na área social e o insere como agenda de governo. Em um segundo momento, essa influência encontra-se entre o grupo de especialistas e acadêmicos que estiveram ativos e produzindo ideias e significados que contribuíram para a construção e sustentação do ideário que permeou a formação do SISAN.

A aplicação da revisão de literatura para situar o Estado da arte somada a análise documental e do conteúdo das entrevistas evidenciou no SISAN, os elementos que o configuram como sistema institucional cuja trajetória se mostra dependente do modelo de políticas sociais implantadas pelo Estado brasileiro e das aprendizagens dos agentes do Estado e atores da sociedade atuantes sobre a área de alimentação e nutrição como questão social relevante.

No período estudado, foi possível observar a perda paulatina da centralidade da agenda da SAN, em um modelo de Estado capitalista e de economia fortemente baseada na agricultura de exportação, cujos modelos de intervenção sobre a questão alimentar acabaram por privilegiar programas de distribuição de renda e de alimentos, todos estes com colegiados e instancias próprias de decisão e encolheram as ações estruturantes do sistema de SAN. Um parêntese pode ser feito com relação ao avanço das ações de suporte à agricultura familiar e criação do Programa de Aquisição de Alimentos, que propiciou mudanças importantes na economia rural, mas que igualmente sofre de alterações que o fazem reduzir sua capacidade de intervenção, como apontado na fala de muitos dos atores consultados.

A partir dos elementos que permearam o processo de formulação e implementação, foi possível traçar com base nos referenciais teóricos adotados algumas analises que podem explicar algumas das potencialidades e fragilidades percebidas no decorrer da trajetória do SISAN.

De acordo com o conceito de dependência da trajetória, advindo dos referenciais neoinstitucionais, as mudanças nas instituições ocorrem a partir de uma dinâmica de eventos que conserva traços de suas origens. Os arranjos institucionais propostos para o SISAN, reproduzem trajetórias de sistemas sociais já implantados e mantem parte do modelo construído para a gestão do PFZ, que paulatinamente vai se adaptando ao modelo do federalismo, com a busca pela crescente adesão dos gestores estaduais e municipais.

A riqueza da construção dos mecanismos institucionais que se colocam 
como instancias de escuta social e compartilhamento de ideias, como é o caso do CONSEA e das conferências periódicas por ele coordenadas, é um dos mecanismos institucionais mais permeáveis e favoráveis ao diálogo e produção de consenso que os atores sociais colocaram na agenda de governo, sendo também reconhecido como de grande capacidade técnica na formulação da política de SAN.

$\mathrm{Na}$ dimensão de alargamento da esfera pública, como possibilidade de um agir baseado no diálogo qualificado de ideias, o CONSEA materializa a positividade da construção de um espaço que produz sentido e consequência às demandas de grupos sociais que ali estejam representados. Se este perfil decorre do modelo consultivo, que como percebido pelas entrevistas, responde pelo equilíbrio de forças entre setores e grupos sociais, favorecendo a participação e a manifestação de interesses na busca de decisões consensuadas, ou se deriva da enorme força política com que foi criado refletindo naquele momento a agenda central do governo federal, o tempo será capaz de narrar.

A síntese das dimensões institucionais mostra a opção pelas estratégias de implantação baseadas na escuta ampla da sociedade com encaminhamento de proposições, na pactuação federativa e na articulação e cooperação horizontal. Sobre a participação social, é inequívoca a avaliação positiva de seu alcance e tradução social.

Se este mecanismo se desgasta com o passar dos anos, na medida em que a dinâmica produzida internamente se expressa no diálogo com o Estado, por meio de exposições de motivos, perde força e influencia, como referido nas entrevistas, ele ainda é percebido pelos atores da sociedade civil e pelos especialistas como um espaço de resistência frente ao enfraquecimento da agenda de SAN.

A partir das entrevistas, foi possível corroborar a importância do CONSEA na reconstrução do projeto nacional da SAN como elemento de disseminação das ideias que ajudaram a sustentar sua institucionalização no âmbito de governo.

Da pluralidade de seus representantes, da capacidade de seus especialistas até a diversidade temática tratada ali, o CONSEA é na dimensão institucional, um dos espaços mais prestigiados da governança de SAN. Sendo conselho consultivo com atribuições de articulação, concertação e proposição obteve status privilegiado na formação do SISAN e manteve em pauta temas que mobilizam posições sensíveis para a agenda de SAN. Esse aspecto primordial para a alavancagem do SISAN encontra-se em momento emblemático, diante da necessária expansão de 
sua base municipal e estadual. É evidente que sua potencialidade se construiu voltada ao nível central da 
política tendo essa base local disseminada por movimentos sociais advindos da Ação da Cidadania e do PFZ, e outros que foram se somando ao longo do tempo reunindo os grupos de atores da SAN.

Considerada uma opção política consciente, como aponta as entrevistas, acerca do caráter de assessoramento do CONSEA à Presidência da República, tal opção, a depender do executivo federal, pode a longo prazo fragilizar as relações que mantém com seus pares nos demais níveis federativos, afetando todo o SISAN. Se o modelo funciona bem para o nível central criando um conselho de alto nível capaz de gerir a governança de SAN, talvez para configurar uma base federativa, seja necessário direcionar um olhar para os municípios na busca de experiências que possam ser disseminadas.

As informações acerca da criação e atuação dos CONSEAS estaduais e municipais, de acordo com os dados da MUNIC/ESTADIC e na visão dos informantes são menos especificas.

Embora haja o reconhecimento que os Estados chegaram primeiro na construção de seus conselhos, somente um Estado da federação mantinha o conselho diretamente ligado ao governo, seguindo a vinculação observada no CONSEA, sendo que os demais eram vinculados setorialmente. Embora há já representação de Presidentes de Conselhos Estaduais no CONSEA, não se pode afirmar se estes têm suas demandas inseridas nas agendas dos organismos federais que compõem o SISAN. Quando entrevistados, os informantes referiram-se ao pouco espaço ocupado com experiências locais e temas regionais no âmbito do pleno do CONSEA, bem como não foram mencionados como atores capazes de influenciar a agenda federal.

Os números da MUNIC/ESTADIC com relação aos conselhos municipais mostram que 1/3 dos municípios brasileiros afirmam ter implantado os conselhos, o que representa um número expressivo, considerando as demais instancias do SISAN, em nível local. Grande parte deles adota o modelo consultivo, associando outras funções como a de controle e são subordinados setorialmente. Neste aspecto, sendo os recursos das ações de SAN fragmentados em programas que já contam com estruturas próprias de controle, questiona-se as atribuições destes com relação as ações gerais de SAN.

A importância crescente que a CAISAN vem assumindo na transposição da etapa de formulação para a implementação complementa o ciclo de gestão da 
política, que se volta aos entes subnacionais como forma de dar consequência ao SISAN, em observância ao que foi formulado na etapa anterior.

No entanto, o risco de fragmentação da SAN, com o fortalecimento de agendas próprias dos programas como é o caso do PBF, do PNAE e PAA, representa risco ao modelo podendo esvazia o movimento de consolidação da institucionalidade sub- regional da SAN. É grande a aposta na capacidade indutora do Plano Nacional de SAN para inspirar as esferas estaduais e municipais na elaboração de planos locais. Sua inclusão como critério de adesão ao SISAN juntamente com a criação dos conselhos e instancias locais vem gerando um movimento a favor da construção dos pactos de adesão ao sistema.

Este processo tem sido enfatizado a partir de 2012, com a edição de inúmeras resoluções da CAISAN, acerca da organização estadual e municipal do sistema, e a busca de formalização da adesão de grande número de municípios ao SISAN. Mesmo com esta inflexão a favor da descentralização da política de SAN, o processo tem sido mais lento do que o esperado e demandado um esforço maior da burocracia central nos processos de pactuação e convencimento na medida em que a própria agenda perda terreno. O plano por sua vez incorre no mesmo vazio encontrado nos documentos anteriores, a falta de orientação sobre recursos e financiamento como garantia de sua implantação.

Os propósitos de SAN alicerçados em um projeto político partidário, como referido pelos entrevistados, pode dificultar a adesão de gestores locais mais distantes ou mesmo contrários a esta pauta social. Mesmo que o PLANSAN reúna as ações e programas expressivos da SAN em um documento que busca medir as intenções do governo, e seja mais um passo na consolidação institucional do SISAN, sua capacidade indutora ainda é limitada pela imprecisão da fonte de recursos e por ser de caráter voluntário, e ocorrer em um período marcado pelo afastamento da agenda de SAN do eixo central das políticas federais.

As informações emanadas da MUNIC/ESTADIC mostram a dispersão da organização do SISAN no âmbito estadual e municipal e sua aproximação cada vez maior com a esfera da assistência social como mecanismo de coordenação. Este modelo parece apontar para um recuo na dinâmica da SAN, como uma agenda de desenvolvimento capaz de sensibilizar e envolver ações mais estruturantes, tal qual idealizado inicialmente. No entanto, permite inferir que a organização territorial do SISAN está alicerçada na atuação destes dois setores. 
É reconhecida a atuação do setor saúde na constituição do sistema ao transportar para o SISAN algumas ações e mecanismos de enfrentamento da questão

alimentar seja por intermédio das ações prestadas no nível da atenção básica local, ou pela política de promoção da saúde ou ainda pela regulação exercida pela vigilância sanitária, marcaram também a trajetória da SAN. A incorporação da segurança alimentar e nutricional como determinante da saúde e parte integrante da política de saúde, possibilitou uma assimilação desta agenda pelos profissionais de saúde no âmbito estadual e municipal e sua participação ativa nos fóruns de SAN, como atesta o expressivo número de municípios cuja coordenação do sistema está a cargo da área da saúde. Na literatura consultada, há o reconhecimento de que a institucionalidade conferida a PNAN é um dos marcos da construção do SISAN. A constituição do SUAS e a fortaleza que sua institucionalização alcançou nos últimos anos, com a expansão da oferta de serviços em Estados e municípios também foi percebida como elemento de sustentação territorial do SISAN em seu aspecto institucional. Se este movimento será suficiente para expandir o sistema e realizar o enfretamento de questões estruturais que a agenda de SAN advoga, ainda não se pode afirmar.

Os critérios de adesão não têm sido suficientes para garantir o avanço na capitalização do SISAN, fato este corroborado pelo baixo percentual de municípios, que cumprem os requisitos propostos, ou seja, reunir instancias como conselho e câmara e elaborar o plano municipal. Reconhece-se, por parte dos entrevistados que o governo federal tem como um de seus desafios imediatos a expansão do sistema para os municípios. Reconhece-se ainda que a falta de definição sobre atribuições e responsabilidades dos entes federados e a falta de mecanismos de financiamento fragilizam o processo de descentralização.

Aparentemente estes parecem ser uma das principais barreiras ao processo de implementação do SISAN. No entanto, ao longo desta tese, outras exterioridades puderam ser observadas. A perda de centralidade da agenda, a fragmentação da própria constitucionalidade da SAN, na medida que os programas avançam sem necessariamente se submeteram aos mecanismos de coordenação e de dialogo existentes, o reduzido número de ações e de recursos que estão sob competência direta do SISAN, vão se mostrando como componentes de enfraquecimento da 
agenda de SAN. Como pode ser observado nos achados da revisão bibliográfica realizada e corroborado durante as entrevistas, há registros e relatos sobre a perda sucessiva da centralidade da agenda, que aos poucos subordina as ações e os resultados da SAN ao Programa Bolsa Família. Nesse aspecto, a dimensão de coordenação do SISAN ao exigir mecanismos institucionais mais sofisticados e mais inclusivos com relação ao conjunto de temas tratados, e a necessidade de temporalidades diferenciadas para que a SAN seja alcançada em sua integralidade, pode ser interpretada como um elemento que dificultou o avanço de sua implementação

O segundo momento, corroborado pelas entrevistas aqui realizadas, é o deslocamento da agenda da SAN para o combate à pobreza e erradicação da miséria, o Plano referente a estes objetivos, embora mantenha o eixo da SAN, empurra as ações do SISAN para um ponto mais distante de influência no âmbito do governo central, o que somado aos demais fatores institucionais vai desequilibrando seu processo de implementação.

$\mathrm{O}$ conceito de dependência da trajetória pode ser explicativo tanto dos mecanismos institucionais de origem setorial escolhido para gerir o SISAN, na medida em que havia um aprendizado social da burocracia de Estado e da sociedade civil em lidar com tais mecanismos como também esclarece a força e a resistência que este conjunto de mecanismos representa diante de possíveis processos de mudança.

Daí referenciais de participação e intersetorialidade advindos das experiências do SUS são colocadas na formulação do SISAN que os amplia, dado ao contexto que influencia a geração de políticas mais recentes. A partir dos achados desta tese, corrobora-se com a proposição de que a integração setorial e a conjugação de esforços vêm permeando a atuação do governo na condução das políticas sociais, mas não prescinde de um componente legitimo de coordenação.

No caso do SISAN, a complexidade de temas e de setores que o sistema busca alinhar coloca-o em um patamar de enfrentamento de conflitos centrais da sociedade brasileira, como a questão da terra, da produção sustentável de alimentos, de um consumo saudável sem uso de agrotóxicos e sementes transgênicas, que os referenciais setoriais de seleção de instrumentos de coordenação sejam insuficientes para responder aos seus propósitos.

A circunscrição da SAN às políticas de acesso aos alimentos com um forte 
componente de inclusão de povos tradicionalmente ausentes das políticas públicas nacionais e com recortes de gênero especialmente valiosos no âmbito rural também pode refletir a dinâmica de coordenação existente no governo brasileiro, que ainda não dispõe de mecanismos inovadores de governança. O risco desta dinâmica é esvaziar cada vez mais o sentido com o qual a SAN ganhou a agenda social e representou um ponto de inflexão nas políticas de alimentação e nutrição desde então.

Pelas informações quantitativas, o SISAN parece se alojar em setores cuja organização sistêmica de oferta de serviços se instalaram primeiro nos municípios a saber assistência social e saúde. Estes mesmos setores participam da gestão intersetorial do PBF, gerindo suas condicionalidades de saúde e respondendo pelo cadastro de beneficiários. A outra relação de força representada pela aproximação de interesses em ações conjuntas entre PNAE e PAA, não aparece como dados quantitativos relevantes, mas é expressiva na fala dos atores entrevistados como representantes de um modelo de alta aderência nos pequenos e médios municípios movimentando setores da produção familiar de alimentos e gerando renda no campo. Diante da limitação dos dados não é possível afirmar se há dicotomia de coordenação em ares urbanas e rurais, o que enseja um estudo mais aprofundado sobre a distribuição dos modelos de coordenação do SISAN nestes territórios.

As informações acerca do orçamento do SISAN também mostram a ambiguidade com que esta figura nos planos orçamentários nacionais. Um grande número de setores aporta seus orçamentos para o programa de SAN como demostrado nos capítulos anteriores.

Para efeitos de análise aqui efetuada, e considerando os programas mencionados com maior frequência pelos entrevistados e retratados nos artigos consultados, quais sejam os que estão sobre o comando do MDS, PBF e o aporte do PNAE, estes representam 1/5 do orçamento idealizado e entre estes cerca de 90\% referem-se exclusivamente ao PBF. Tal dicotomia, entre o que se retrata no orçamento federal, a depender dos recortes realizados, e o que se vincula a coordenação central de SAN é outro elemento de confusão que permeia a análise da implementação do SISAN.

Nas abordagens de análise de políticas públicas, tanto os mecanismos de orçamento como de financiamento são elementos indutores da expansão da política social. Nesse caso, há ambiguidade na análise orçamentária, decorrente de um 
recorte muito amplo de programas que na peça orçamentaria estão classificados como sendo vinculados a SAN e ocorre a ausência de mecanismos de financiamento diretos que se conformem como um mecanismo institucional robusto na indução da consolidação do na construção do sistema.

Os Estados recebem financiamentos federais para atividades de capacitação e fomento à produção orgânica, a implantação de tecnologias de acesso à agua para consumo humano, manutenção de feiras livres e doação de alimentos. Ao analisar o

repasse do governo federal verificou-se -se que a atividade de maior cobertura mais localizada regionalmente foi a implantação de tecnologias de acesso à água para consumo humano. No entanto, estas atividades também são referidas como sendo exercidas com recursos próprios, o que não é suficiente para afirmar se estas ações já seriam desenvolvidas ou passaram a ser desenvolvidas após o aporte de recursos federais, impossibilitando a análise do papel indutor do financiamento para a implementação do SISAN

No referencial de análise de políticas públicas, uma não decisão, é uma decisão. Ela acontece por enfrentar obstáculos diversos de graus de intensidade variados que fazem com que a situação, embora reconhecida e problematizada pelos atores da política se prolongue sem que alcance uma solução. O SISAN enfrentou e enfrenta não- decisões que afetaram sua conformação como agente da política de SAN, a tomar a questão referente ao seu orçamento e ao seu financiamento. Embora não se possa afirmar que não existe orçamento nem financiamento, pode-se supor que é uma questão que fica no meio do caminho enquanto sustentação do sistema e da viabilização da política, que não se faz universal nem abrangente como seu proposito enuncia.

A conformação do MDS como operador do SUAS e do PBF e a alocação da SAN sob sua coordenação, emprestam a tendência do arcabouço normativo seguido pelo SISAN, que perfaz um dos conjuntos de normas do SISAN dos mais sofisticados e completos. Em prazo de não menos que 10 anos, a SAN se tornou direito constitucional, consagrou uma lei orgânica própria com um decreto federal, sucessivas resoluções que o normatiza, desembocando em um plano nacional que lhe dá visibilidade e possibilidade de aderência.

Se como visto anteriormente, a descentralização de uma política social, como condição para sua implementação, não ocorre prontamente, o mecanismo de 
adesão dos entes federados é elemento imperativo para sua consecução.

No caso das políticas sociais brasileiras, é reconhecida a dificuldade de alguns municípios, especialmente os de pequeno porte, serem parceiros de primeira hora de programas lançados pelo governo federal. O levantamento quantitativo realizado aqui, mostrou a dificuldade dos municípios de pequeno porte em constituir ou delegar alguma estrutura para coordenar as ações do SISAN, o que aponta para o fato de que a uniformidade da regra nem sempre alcança municipalidades pequenas, levantando a necessidade de se pensar em modelos diferenciados de adesão e ou de pactuação de ações de SAN para estas localidades.

Soma-se a isto a ideia subjacente presente nas entrevistas de que falta materialidade aos serviços ofertados na ponta, deixando em aberto para os gestores a pergunta sobre o que aderir trará para melhorar as condições locais. Uma das possíveis respostas é que a visibilidade que a SAN assume no município, encontrase ofertada pelos programas que o compõem, mesmo que nas instancias federais exista uma importante atuação dos atores voltada a sua melhoria, por meio de uma participação ativa no CONSEA.

Na literatura pesquisada, as análises e experiências de implementação de políticas demostram que a adesão e o comprometimento do gestor local relacionamse a sua sobrevivência política ou a de seus aliados. Os baixos números, apontam para a possível imprecisão dos benefícios políticos que cercam a adesão ao SISAN. Seja pela falta de nitidez dos conteúdos dos mecanismos institucionais que o compõem, como certifica a dificuldade em se definir um fluxo continuo de financiamento e atribuir responsabilidades além de processos de adesão por vezes circunstanciais, seja porque a oferta de serviços é dispersa e com diferentes pontos de coordenação, seja porque é um projeto político alinhado a um só partido, conforme atesta o percurso documental e empírico trazido por esta tese.

A tese corrobora o aspecto desafiador que o modelo sistêmico da SAN enfrentou em sua primeira década de institucionalização, elencando os contornos de seu processo de implementação. Aponta, como base no referencial neoinstitucional e na abordagem das ideias, o êxito que a trajetória do SAN representa ao conferir uma institucionalidade sólida ao SISAN que contribui para a sua sustentação e possíveis resistências a processos de mudanças que o fragilizem. Expressa as ideias que permeiam a construção do sistema, fundada na adoção de um modelo de desenvolvimento e de governança solidário e voltado a produzir 
transformações na base social, por intermédio de forte participação e inclusão social, o qual enfrenta embates diante do Estado democrático de origem liberal que orienta a formação do Estado brasileiro. Revela os sentidos subjacentes ofertados a etapa de construção do SISAN e a de sua implementação, se na primeira as falam emitem a fortaleza que sua o êxito da construção do sistema representou, para interpretar a etapa seguinte percebe- se uma mensagem de dúvidas e questionamentos sobre o conteúdo da política e seus efeitos na pratica institucional. Revela com base na análise de dados secundários, a fragilidade com que o processo de expansão territorial do sistema vem se desenvolvimento, para a qual a insuficiência de mecanismos institucionais de financiamento perenes e a imprecisão das atribuições sub-regionais são variáveis explicativas.

\section{Limites da Pesquisa}

Os resultados aqui encontrados limitam-se a uma análise do perfil do SISAN, a partir dos mecanismos adotados pelo governo federal, e circunscrita a referências teóricas de médio alcance. A base de dados da ESTADIC /MUNIC ainda não permite analise estatísticas mais robustas com técnicas de análise de tendência em detrimento da temporalidade. Além disso, ela é baseada na concepção unilateral do gestor ou pessoa responsável por responder ao questionário institucional. A utilização de entrevistas semiestruturadas cuja seleção de informantes chaves privilegiou a perspectiva de atuação na esfera federal, tem no limite da técnica, a representação das ideias e significados de atores ativos e comprometidos com a consolidação do SISAN

Novos estudos que contemplem uma análise de triangulação de dados e entrevistas com atores estaduais e municipais poderão elucidar as tensões e avanços do SISAN, a consolidação e as ameaças à SAN no território brasileiro. 


\section{Referências Bibliográficas}

ABRUCIO, Fernando. Luiz. A coordenação federativa no Brasil: a experiência do período FHC e os desafios do governo Lula. Rev. Sociol.Polít. 2005; 24:41-67.

ABRÚCIO, Fernando Luiz. FRANZESE, Cibele. Federalismo e Políticas Públicas: o impacto das relações intergovernamentais no Brasil. In: ARAÚJO, Maria Fatima Infante; BEIRA, Ligia (Orgs.). Tópicos de economia paulista para gestores públicos. Fundap: São Paulo, v.1, 2007, p. 13-31.

ABRUCIO, Fernando Luiz. Três Agendas, seus resultados e um desafio: balanço recente da administração pública federal brasileira. Desigualdade\&Diversidade Dossiê Especial, segundo semestre de 2011, pp.119 -142. 2011.

AKERMAN, Marco et al. Intersetorialidade? IntersetorialidadeS! Ciência \& Saúde Coletiva, Rio de Janeiro, v. 19, n. 11, p. 4291-4300, nov. 2014 .

ALENCASTRO, Luíza et al. Conselhos gestores: uma bibliografia anotada. Projeto Arranjos Participativos Locais. Coordenação: Profa Rebecca Abers, Instituto de Ciência Política, UnB, Brasília, 2007.

ALMEIDA FILHO, Naomar. Transdisciplinaridade e Saúde Coletiva. Ciência \& Saúde Coletiva, Rio de Janeiro, v.2, n.1-2, p.5-20, 1997.

ALMEIDA FILHO, Naomar. Integração Metodológica na Pesquisa em Saúde: nota crítica sobre a dicotomia quantitativo-qualitativo. In: GOLDENBERG, Paulete (Org). O Clássico e o Novo: tendências, objetos e abordagens em ciências sociais e saúde. Rio de Janeiro. Editora Fiocruz, 2003.

ALMEIDA, Carla; TATAGIBA, Luciana. Os conselhos gestores sob o crivo da política: balanços e perspectivas. Serv. Soc. Soc. São Paulo, n.109, jan./mar. 2012.

ANJOS, Luís Antônio; BURLANDY, Luciene. Construção do conhecimento e formulação de políticas públicas no Brasil na área de segurança alimentar. Ciência 
\& Saúde Coletiva [online], v.15, n.1 p.19-22, 2010.

ARRETCHE, Martha Teresa da Silva. Políticas Sociais no Brasil: Descentralização em um estado federativo'. UNESP, São Paulo. Apresentado no XXI encontro da Associação de estudos latino americano. Chicago, Illinois, set.1998. p 24-26 (mímeo).

ARRETCHE, Martha Teresa da Silva. Federalismo e políticas sociais no Brasil: problemas de coordenação e autonomia. São Paulo em Perspectiva, v. 18, n. 2, p.17-26, 2004.

AVRITZER, Leonardo. Instituições participativas e desenho institucional: algumas considerações sobre a variação da participação no Brasil democrático. Opinião Pública, Campinas, v. 14, n. 1, p. 43-64, jun. 2008.

BACARIN José Giácomo; GRISA, CATIA. Políticas públicas e intervenção do Estado na agricultura familiar e na segurança alimentar e nutricional. GT-08. Natal, 2016. Disponível em: <http://www.redesrurais.org.br/7encontrorede/7gts/7gts08/>. Acesso em: 01/12/16.

BARDIN, Laurence. Análise de Conteúdo. Lisboa, Portugal; Edições 70, LDA, 2009.

BENTO, Antônio Maria Veloso. Como fazer uma revisão da literatura: considerações teóricas e práticas. Revista JA (Associação Académica da Universidade da Madeira), nº 65, p. 42-44. 2012.

BOURDIEU, Pierre. Poder simbólico. Rio de Janeiro: Difel, Bertrand Brasil, 1989.

BRASIL. Câmara Intersetorial de Segurança Alimentar e Nutricional. Resolução $n^{\circ}$ 2, de 21 de outubro de 2009. Instituir a comissão responsável por elaborar proposta de Política e Plano Nacional de Segurança Alimentar e Nutricional. Diário Oficial da União, 23 out. 2009.

BRASIL. Ministério da Saúde. Secretaria de Políticas Estratégicas. A Política 
Nacional de Alimentação e Nutrição do Setor Saúde. Informes Técnicos. Rev. Saúde Pública, v. 34, n. 1, p.104-08, 2000.

BRASIL. Lei $\mathrm{n}^{\mathrm{o}}$ 10.689, de 13 de junho de 2003, cria o Programa Nacional de Acesso à Alimentação - PNAA. Diário Oficial da União, de 16 jun. 2003.

BRASIL. Lei $\mathrm{n}^{\circ} 11.346$, de 15 de setembro de 2006, cria o Sistema Nacional de Segurança Alimentar e Nutricional - SISAN, com vistas em assegurar o direito humano à alimentação adequada e dá outras providencias. Diário Oficial da União, de 18 set. 2006.

BRASIL. Decreto n ${ }^{\circ}$. 7.272, de 25 de agosto de 2010. Regulamenta a Lei 11.346, de 15 de setembro de 2006 que cria o Sistema Nacional de Segurança Alimentar e Nutricional - SISAN com vistas a assegurar o direito humano à alimentação adequada, institui a Política Nacional de Segurança Alimentar e Nutricional PNSAN, estabelece o parâmetro para a elaboração do Plano Nacional de Segurança Alimentar e Nutricional e Nutricional. Diário Oficial de União, 25 ago. 2010.

BRASIL. Conselho Nacional de Saúde. Resolução n. 466, de 12 de dezembro de 2012. Diário Oficial de União.13 jun. 2013.

BRASIL. Emenda Constitucional $n^{\circ}$ 64, de 4 de fevereiro de 2010. Diário Oficial de União, 4 fev. 2010.

BRASIL. Lei nº 8472, de 07 de dezembro de 1993. Dispõe sobre a organização da Assistência Social e dá outras providências. Diário Oficial da União 1993; 07 dez.

BRASIL. Lei ${ }^{\circ} 11.346$ de 15 de setembro de 2006. Cria o Sistema Nacional de Segurança Alimentar e Nutricional - SISAN, com vistas em assegurar o direito humano a alimentação adequada e dá outras providencias. Diário Oficial da União, de 2006; 18 de setembro.

BRASIL. Instituto de Pesquisa Econômica Aplicada. O Conselho Nacional de Segurança Alimentar e Nutricional na Visão de seus Conselheiros. Relatório de Pesquisa. Projeto Conselhos Nacionais: perfil e atuação dos Conselheiros. IPEA, 2012. 
BRASIL. Ministério de Desenvolvimento Social. CAISAN [página eletrônica]. Disponível em: 〈http://www.mds.gov.br/segurancaalimentar/caisan/ legislacao>. Acesso em: 23 out. 2013.

BRASIL. Ministério de Desenvolvimento Social. Relação de Instâncias Estaduais de SAN. [Planilha]. Brasília; 2013.

BRASIL. Instituto Brasileiro de Geografia e Estatística. Perfil de Informações Básicas Municipais. Perfil dos Munícipios Brasileiros 2012. IBGE.2013.

BRASIL. Coordenação de Aperfeiçoamento de Pessoal de Nível Superior. Portal de Periódicos-CAPES/MEC. Disponível em:

<http://www.periodicos.capes.gov.br/>. Acesso em: 06 mar. 2015.

BRASIL. Conselho Nacional de Segurança Alimentar e Nutricional. Seminário de Pesquisa em Segurança Alimentar e Nutricional. Relatório Final. Brasília - DF, 2012.

BRASIL. Lei n. 11.346, de 15 de setembro de 2006. Cria o Sistema Nacional de Segurança Alimentar e Nutricional - SISAN com vistas em assegurar o direito humano à alimentação adequada e dá outras providências. Diário Oficial [da] República Federativa do Brasil. Brasília, DF, 15 set. 2006.

BRASIL. Conselho Nacional de Assistência Social. Resolução no 130, de 15 de julho de 2005. Aprova a Norma Operacional Básica de Assistência Social. Diário Oficial da União, 15 jul. 2005.

BRASIL. Ministério da Saúde. Secretaria de Atenção à Saúde. Departamento de Atenção Básica. Política Nacional de Atenção Básica / Ministério da Saúde. Secretaria de Atenção à Saúde. Departamento de Atenção Básica. - Brasília: Ministério da Saúde, 2012.

BRASIL. Pronunciamento do Presidente do CONSEA na solenidade de assinatura do Decreto PNSAN [pronunciamento na internet]. Maluf R. S. Brasília, CONSEA, 2010. [Cerca de 3 p]. Disponível em: 
<http://www3.planalto.gov.br/consea/comunicacao/ discursos/pronunciamento-dopresidente-do-consea-renato-maluf-em-solenidade-de-assinatura-decreto-pnsan>.

Acesso em: abril de 2014.

BURLANDY, Luciene. A construção da política de segurança alimentar e nutricional no Brasil: estratégias e desafios para a promoção da intersetorialidade no âmbito federal de governo. Ciências \& Saúde Coletiva, Rio de Janeiro, v. 14, n. 3, p. 851-860. jun.2009.

BURLANDY, Luciene. A atuação da sociedade civil na construção do campo da Alimentação e Nutrição no Brasil: elementos para reflexão. Ciências \& Saúde Coletiva, Rio de Janeiro, v. 16, n. 1, p. 63-72, jan. 2011.

A construção da política de segurança alimentar e nutricional no Brasil: estratégias e desafios para a promoção da intersetorialidade no âmbito federal de governo. Ciênc. Ciências \& Saúde Coletiva, 2009, v. 14, n. 3, p. 851-860.

BURLANDY, Luciene; MAGALHAES, Rosana; FROZI, Daniela. Políticas Públicas de Segurança Alimentar e Nutricional. In: ROCHA, C; BURLANDY, L; MAGALHAES, R. Segurança Alimentar e Nutricional: perspectivas, aprendizados e desafios para as políticas públicas. Rio de Janeiro: Editora Fiocruz, 2013.

CAROLAN, Michael. The Food and Human Security Index: Rethinking Food Security and 'Growth. Int. Jrnl. of Soc. of Agr. \& Food, Vol. 19, No. 2, pp. 176-200. 2012.

CASTRO, Josué. Geografia da Fome. 10. ed. Rio de Janeiro: Antares, 1984.

COHN, Amélia. Descentralização, Saúde e Cidadania'. In: Revista Lua Nova. n.32,p.15,1994.

CONOVER, William Jay. Practical nonparametric statistics. New York: Wiley, (C)1999.

COSTA, Christiane. G.A. Segurança alimentar e nutricional: significados e 
apropriações. 2008. 259 f. Dissertação (Mestrado em Saúde Pública) Universidade de São Paulo, São Paulo, 2008.

DAGNINO, Evelina. Sociedade civil, espaços públicos e a construção democrática no Brasil: limites e possibilidades. In: (Org.). Sociedade civil e espaços públicos no Brasil. Rio de Janeiro: Paz e Terra, 2002. p. 279-303.

DELGADO, Guilherme Costa. Do capital financeiro na agricultura à economia do agronegócio: meio século de mudanças cíclicas (1965-2012)’ - (no prelo)

DEMO, Pedro. Politicidade: razão humana. Campinas: Papirus; 2002.

DRAIBE, Sonia. A experiência brasileira recente de reforma dos programas sociais. Socialis, v. 5. 2001.

. A nova institucionalidade do sistema brasileiro de políticas sociais: os conselhos nacionais de políticas sociais. Cadernos de Pesquisa, n. 35, NEPP/Unicamp, Campinas, 1998.

. As políticas sociais brasileiras: diagnósticos e perspectivas. Para a

década de 90: prioridades e perspectivas de políticas públicas. Brasília, 1990.

FAO - Organização das Nações Unidas para Agricultura e Alimentação. World Food Security: a Reappraisal of the Concepts and Approaches. Director General Report. Roma: FAO, 1983.

FAO - Organização das Nações Unidas para Agricultura e Alimentação. Conferência Mundial de los Alimentos. Roma, 1974.

FAO - Direito à Alimentação • ESA • (C) FAO, 2012 Ficha informativa desenvolvida em colaboração com a FIAN. Autoria de Natalia Landivar e Martin Wolpold-Bosien, tradução por Vilmar Schneider, 2012.

FERRETTI, Celso. O pensamento educacional em Marx e Gramsci e a concepção de politecnia. Trabalho, Educação e Saúde, Rio de Janeiro, v. 7, suplemento, p. 105-128, 2009.

FRIEDMANN, Harriet. The Political Economy of Food: a Global Crises. New Left Review, n. 197, 29-57, 1993. 
GOHN, Maria da Glória. O papel dos conselhos gestores na gestão urbana (parte III: Planejamento, gestão e democracia: escalas e sentidos contemporâneos das intervenções urbanas). In: TORRES RIBEIRO, Ana Clara (Comp.). Repensando la experiencia urbana de América Latina: cuestiones, conceptos y valores. Buenos Aires: Consejo Latinoamericano de Ciencias Sociales (CLACSO), 2000. p. 175201. Disponível em: 〈http://168.96.200.17/ar/libros/urbano/gohn.pdf >. Acesso em: 17 ago. 2009.

. Movimentos sociais na contemporaneidade. Rev Bras Educ, v. 16, n.

47, p. 333-361, 2011.

GOMEZ, Desider K. A Fome Zero e a produção acadêmica realizada no âmbito dos programas de pós-graduação (2003-2009). In: FRANÇA, Caio Galvão; GROSSI, Mauro Eduardo; SILVA, José Graziano (Orgs.). Fome Zero: uma História Brasileira. Brasil. Ministério do Desenvolvimento Agrário, Brasília, 2010.

GONZÁLEZ REY, F. O valor heurístico da subjetividade na investigação psicológica. Em F. González Rey (org.), Subjetividade, complexidade e pesquisa em psicologia (pp. 27- 51). São Paulo: Pioneira Thomson Learning. 2005

HABERMAS, Jurgen. Direito e Democracia: entre facticidade e validade. Vol I .2 ed. Tradução Flávio Beno Siebeneichler. Rio de Janeiro: Tempo Brasileiro, 2003.

HALL, Peter. The role of interests, institutions, and ideas in the comparative political economy of industrialized nations". In: LICHBACK, Mark \& ZUCKERMAN, Alan (orgs.). Comparative politics: rationality, culture and structure. Nova York, Cambridge University Press, 1997, p. 174-207.

HALL P. Taylor R. As três versões do Neo-Institucionalismo. Lua Nova, n. 58: p. 193-223, 2003.

HAAS, Peter M. Introduction: epistemic communities and international policy coordination. International Organization, v. 46, n. 1, p. 1-35, 1992. 
HOOD, Christopher and JENNINGS, Will and HOGWOOD, BRIAN and BEESTON, Craig. Fighting fires in testing times: exploring a staged response hypothesis for blame management in two exam fiasco cases CARR Discussion Papers, DP 42. Centre for Analysis of Risk and Regulation, London School of Economics and Political Science, London, UK, 2007.

INSTITUTO BRASILEIRO DE GEOGRAFIA E ESTATÍSTICA. Perfil dos Estados e dos municípios brasileiros 2014 / IBGE, Coordenação de População e Indicadores Sociais. - Rio de Janeiro: IBGE, 2015. 126p.

JESSOP, Bob. The capitalist state - marxist theories and methods. Martin Robertson \& Company Ltd.. Oxford. 1983.

JUNQUEIRA, Luciano A. Prates. Intersetorialidade, transetorialidade e redes sociais na saúde. Rev. Adm. Pública, n. 34, p. 35-61, 2000.

- Novas formas de gestão na saúde: descentralização e intersetorialidade. Saúde soc., São Paulo, v. 6, n. 2, p. 31-46, dez. 1997.

KINGDOM, John W. Agendas, alternatives and public policies. 2. ed. NewYork: Harper- Collins College Publishers, 1995.

LAZIN, Frederick A. Politcs and Policy Implementation:Project Renewal in Israel. Vol. 15, Contemporary Jewry. No. 1, pp. 200-202. December 1994.

LEÃO, Marília Mendonça; MALUF, Renato S. A construção social de um sistema público de segurança alimentar e nutricional: a experiência brasileira / Marília Leão; Renato S. Maluf - Brasília: Ação Brasileira pela Nutrição e Direitos Humanos (ABRANDH), 2012.

MACHADO Moisés; ROCHA Daniele Fernandes. Dos movimentos sociais à implementação do Programa Fome Zero (1993-2013): a trajetória da cidadania alimentar no Brasil - 20 anos de Ação da Cidadania e 10 anos do Programa Fome Zero [conferência]. IV CONGRESO INTERNACIONAL EN GOBIERNO, ADMINISTRACIÓN Y POLÍTICAS PÚBLICAS]. Publicaciones Comunidad GIGAPP [cerca de 30 p]. Disponível em: <http://gigapp.org/es/lista- 
publicaciones?view=publication \&task=show \&id=875\#. VCXSysakrwk >. Acesso em: 20 jan. 2014.

MAHONEY, James; THELEN, Kathleen. Explaining Institutional Change: Ambiguity, Agency, and Power. Cambridge University Press, 2010.

MALUF Renato S. J. Segurança Alimentar e Nutricional. Petrópolis: Vozes, 2007.

Quadro institucional e de políticas públicas para a segurança

e soberania alimentar no Brasil [paper]. PCT/ IICA/MDA/NEAD. 2010.

Disponível em: http:// www2.membrosbrasilcma.org.br/docs/QUADROINSTITUCIONALEDEPOLITICAS PUBLICASPARAASEGURANCAESOBERANIAALIMENTARNOBRASIL.pdf. >. Acesso em: 10 maio 2013

MALUF Renato S. J; MENEZES, F.; VALENTE, F.S. Contribuição ao tema da segurança alimentar no Brasil. Cadernos de Debate, v. IV, p. 66-88, 1996.

MAX-NEEF, Manfred; ELIZALDE, Antonio; HOPENHAYN, Martín. Desarrollo a escala humana - Opciones para el futuro. Madrid, marzo de 2010. Recurso electrónico disponible en HTML y PDF: http://habitat.aq.upm.es/deh/. Acesso em 13 de fevereiro de 2015.

MINAYO, Maria Cecília de Souza; GOMEZ, Carlos Minayo. Difíceis e Possíveis Relações entre Métodos Quantitativos e Qualitativos nos Estudos de Problemas de Saúde. In: O Clássico e o Novo: tendências, objetos e abordagens em ciências sociais e saúde / Organizado por Paulete Goldenberg, Regina Maria Giffoni Marsiglia, Mara Helena de Andréa Gomes. Rio de Janeiro, Editora Fiocruz, 2003.

MINAYO, Maria Cecília de Souza. O desafio da pesquisa social. In: MINAYO, Maria Cecília de Souza; GOMES, Suely Ferreira Deslandes Romeu (org.). Pesquisa social: teoria, método e criatividade. 27ª ed. Petrópolis: Vozes, 2008, p.9-29.

MONTAGNER, Miguel Ângelo; MONTAGNER, Maria Inez. A teoria geral dos 
campos de Pierre Bourdieu: uma leitura. Tempus - Actas de Saúde Coletiva Antropologia e Sociologia da Saúde: novas tendências. Brasília, v.5, n. 2, 2011.

NASCIMENTO Renato Cavalheira. A fome como uma questão social nas políticas públicas brasileiras. IDeAS, v. 3, n. 2, p. 197-225, 2009.

NASCIMENTO, Suely. Reflexões sobre a intersetorialidade entre as políticas públicas. Serv. Soc. Soc., São Paulo, n. 101, p. 95-120, mar. 2010.

NYE, Joseph S. The Future of Power. New York: Public Affairs, 2011.

NORONHA, José Carvalho, LEVCOVITZ, Eduardo. AIS-SUDS-SUS: Os caminhos do Direito à saúde "In: GUIMARÃES, Reinaldo, TAVARES, R (orgs). Saúde e Sociedade no Brasil: anos 80. Rio de Janeiro: Relume Dumará, 1994.

NUNES, José Luís Feijó. Políticas públicas e descentralização: o impacto da municipalização na prática docente. Tese. Pontifícia Universidade Católica de São Paulo. 2010.

OLIVEIRA Lucas Conde; PINHEIRO, Roseni. A participação nos conselhos de saúde e sua interface com a cultura política. Ciência \& Saúde Coletiva, v. 15, n. 5, p. 2455-2464, 2010.

ONU. Assembleia Geral das Nações Unidas. Conselho de Direitos Humanos. Report of the Special Rapporteur on the right to food, Olivier De Schutter. Building resilience: a human rights framework for world food and nutrition security. 2008. Disponível em: <http://www.fanrpan.org/documents/d00591/Building_resilience_de_Schutter_Sep

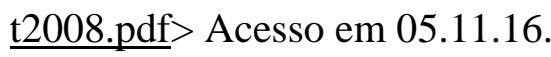

OSTROM Elinor; GARDNER, Roy; WALKER, James. Rules, Games, and Common-Pool Resources. The University of Michigan Press, 1994.

OXFAM - Diminuindo as distancias: a reforma da governança global da segurança alimentar. Nota informativa de 16 de novembro de 2009. Disponível em: 
<www. oxfam.org.br>. Acesso em: janeiro 2017

PEREIRA, Adelyne Maria Mendes. Análise de Políticas Públicas e Neoinstitucionalismo Histórico: Ensaio Exploratório Sobre o Campo e Algumas Reflexões. In: Guizardi, Francine L. (Org.) Políticas de Participação e Saúde. Rio de Janeiro: EPSJV; Recife: Editora Universitária - UFPE, 2014.

PEREIRA Potyara Amozeneida Pereira. Política Social, cidadania e Neoliberalismo: reflexão sobre a experiência brasileira in: Carvalho DBB, Demo P, Sousa NHB, organizadores. Novos paradigmas da política social. Brasília: UnB; 2002.

PESSANHA Lavínia Davis Rangel. A experiência brasileira em políticas públicas para a garantia do direito humano ao alimento. Rio de Janeiro: Escola Nacional de Ciências Estatísticas, Departamento de Ensino e Pesquisa, texto para discussão, $\mathrm{n}^{\circ}$ 5, 2000.

PIERSON, Paul. Polites in Time: History, Institutions and Social Analysis.

Princeton University Press, 2004.

PINHEIRO, Anelise Rizzolo. Análise histórica do processo de formulação da política nacional de segurança alimentar e nutricional (2003-2006): atores, ideias, interesses e instituições na construção de consensos. 2009. 236f. Tese (Doutorado em Serviço Social) - Universidade de Brasília, Brasília, 2009.

POULANTZAS, Nico.1978a. State, Power, Socialism. London: New Left.

PRADO ET al. Alimentação e Nutrição Como Campo Científico autônomo no Brasil: conceitos, domínios e projetos políticos. Rev. Nutr., Campinas, v. 24, n.6, p. 927-937, nov./dez, 2011.

PRZEWORSKI, Adam. Sobre o desenho do Estado: uma perspectiva agente $\mathrm{x}$ principal. In: BRESSER PEREIRA, Luiz Carlos; SPINK, Peter (Orgs.). Reforma do Estado e administração pública gerencial. Tradução de Carolina Andrade. Rio de Janeiro: Editora FGV, 2003. P. 39-73.

RAICHELIS, Raquel. Esfera pública e conselhos de assistência social. $2^{\text {a }}$ edição revisada. São Paulo: Cortez; 2000. 
RECINE, Elisabetta; VASCONCELLOS, Ana Beatriz. Políticas nacionais e o campo da alimentação e nutrição em saúde coletiva: cenário atual. Ciências $\&$ Saúde Coletiva, Rio de Janeiro, v. 16, n. 1, p. 73-79, Jan. 2011.

RIGON, Silvia Amaral; SCHMIDT, Suely Teresinha; BÓGUS, Claudia Maria. Desafios da nutrição no Sistema Único de Saúde para construção da interface entre a saúde e a segurança alimentar e nutricional. Cad. de Saúde Pública, v. 32, n. 3, 2016.

ROCHA, CV. Neoinstitucionalismo como modelo de análise para as Políticas Públicas. Civitas - Revista de Ciências Sociais, v. 5. n. 1, jan.-jun. 2005.

SALLES PINTO, Henrique. A segurança alimentar e nutricional no Brasil. Textos para Discussão 150; 152. ISSN: 1983-0645. Brasília: Senado Federal, Consultoria Legislativa. Disponível em: http://www2.senado.leg.br/bdst/handle/id/502818. Acessado em 17/06/16

SAMPAIO, Rosana Ferreira; MANCINI, Marisa Cotta. Estudos de Revisão Sistemática: um guia para síntese criteriosa da evidência científica. Rev. Bras. Fisioter. São Carlos, v. 11, n. 1, p. 83-89, Jan./fev. 2007.

SCOTT, William Richard. Institutions and Organizations. Second Edn. California: Thousand Oaks: Sage, 2001.

SHETTY, Prakash. From food security to food and nutrition security: role of agriculture and farming systems for nutrition. Current Science, Vol. 109, No. 3, 10 August 2015.

SILVA, L.A.L. A Construção Federal da Intersetorialidade na Política de Desenvolvimento Social Brasileira: o caso do Programa Bolsa Família. 2013. 143 f. Dissertação (Mestrado em Ciência Política) - Universidade Federal de São Carlos. São Carlos, 2013.

SILVA, Frederico Barbosa; JACCOUD, Luciana; BEGHIN, Nathalie. Políticas sociais no Brasil: participação social, conselhos e parcerias. In: JACCOUD, 
Luciana (Org.). Questão social e políticas sociais no Brasil contemporâneo. Brasília, DF: IPEA, 2005. p. 373-407.

SIMIONATTO, Ivete. Gramsci: sua teoria, incidência no Brasil, influencia no serviço social. 4 ed. São Paulo: Cortez, 2011.

SILVA, Rosangela Viana Alves. Descentralização e municipalização: a redefinição do papel do Estado no âmbitolocal. Disponível em:

<http://www.anpad.org.br/ diversos/trabalhos/EnANPAD/ enanpad_2000/ADP/2000_ADP425.pdf >. Acesso em: 12.06.16

STRELEC, Tamara; COSTA, Valeriano Mendes Ferreira. Cooperação e Relação intergovernamental: Classificação, Características e Formatos Existentes à luz da Experiência Brasileira. RIEM, Nº 14, Ano VII, ISSN 0719-1790, pp37-62, 2006.

TAKAGI, Maya. A implantação da política de segurança alimentar e nutricional no Brasil: seus limites e desafios. 2006. Tese (Doutorado em Desenvolvimento Econômico) - Universidade Estadual de Campinas, Campinas, 2006.

TATAGIBA, Luciana. Conselhos gestores de políticas públicas e democracia participativa: aprofundando o debate. Rev. Sociol. Polít. n. 25, p. 209-213, 2005;

TAPIA, Jorge; GOMES Eduardo R. Tempo Social. Revista de Sociologia da USP, v. 20, n. 1, jun. 2008.

THÉRET, Bruno. As instituições entre as estruturas e as ações. Lua Nova, n. 58, p. 225-254, 2003.

VAITSMAN, Jeni. Concepção e gestão da proteção social não contributiva no Brasil. -- Brasília: Ministério do Desenvolvimento Social e Combate à Fome, UNESCO, 2009.

VALENTE, Flavio Schieck, Direito humano à alimentação: desafios e conquistas. Cortez Editora, São Paulo, 2002.

VASCONCELOS, Francisco Assis Guedes. Combate à fome no Brasil: uma 
análise histórica de Vargas a Lula. Rev. Nutr. v. 18, n. 4, p. 439-457, 2005.

VOSGERAU D.S.A.R.; ROMANOWSKI, Joana P. Estudos de revisão: implicações conceituais e metodológicas. Rev. Diálogo Educ., v. 14, n. 41, p. 165189, 2014.

YASBEK, Maria Carmelita. O programa Fome Zero no contexto das políticas sociais brasileiras. São Paulo em Perspectiva, v. 18, n. 2, p. 104-112, 2004. 


\section{Anexo 1 - Roteiro de Entrevista Semiestruturada}

Tema: Os caminhos institucionais da Segurança Alimentar e Nutricional no Brasil, $2004-2014$.

Objetivo: Análise da Institucionalidade do Sistema Nacional de Segurança Alimentar e Nutricional e da Política Nacional de Segurança Alimentar e Nutricional.

Entrevistado:

Data:

1. Considerando a abrangência do conceito de SAN como você define a organização do Estado brasileiro para promover a SAN? Identifique fatores que facilitam e dificultam essa operacionalização.

2. O SISAN e a PNSAN são marcos legais para a SAN. Quais elementos positivos e negativos você destaca na implementação do SISAN, considerando o período de 2004 a 2014 ?

3. Em sua opinião, em uma escala de 0 a 5 como você classifica a relevância de seus princípios e diretrizes para a institucionalidade de SAN Por quê? 


\begin{tabular}{|l|l|}
\hline Princípios e Diretrizes & Observações \\
\hline $\begin{array}{l}\text { Participação social em todas as etapas da gestão das políticas públicas, em } \\
\text { todas as esferas de governo; }\end{array}$ & \\
\hline Universalidade e Equidade; & \\
\hline Transparência; & \\
\hline Autonomia e dignidade das pessoas; & \\
\hline Promoção da intersetorialidade; & \\
\hline Descentralização e Articulação; & \\
\hline Monitoramento de a situação alimentar; & \\
\hline $\begin{array}{l}\text { Conjugação de medidas diretas e imediatas de garantia de acesso à } \\
\text { alimentação adequada; }\end{array}$ & \\
\hline Articulação entre orçamento e gestão; & \\
\hline Estimulo ao desenvolvimento de pesquisa e à capacitação. & \\
\hline
\end{tabular}

4. Como você entende a promoção da intersetorialidade em SAN?

5. Nesse âmbito, como você define a atuação do governo federal enquanto coordenador do SISAN?

6. Em que medida, as demandas dos múltiplos setores que compõe a SAN são incorporadas no SISAN e na PNSAN?

7. No âmbito da promoção da participação social, como você define a atuação do Governo federal?

8. Em sua opinião, como a sociedade civil influencia o processo decisório no nível federal? Se possível cite um exemplo positivo e um exemplo negativo. 
9. Em sua opinião, quais são os atores /setores que participam efetivamente do processo decisório em SAN? Por quê?

10. Quanto à descentralização e articulação, como você define a atuação do governo federal, enquanto coordenador do sistema?

11. Em que medida as demandas dos demais níveis de governo influenciam as prioridades e as estratégias do SISAN/PNSAN?

12. No âmbito da articulação entre orçamento e gestão como você define a atuação do governo federal? Justifique.

13. Das iniciativas, programas e ações relacionadas nos dois últimos PPA (2008-2011 e 2012 - 2015) que você conhece, qual ou quais delas você destaca como sendo a mais expressiva para a promoção da segurança alimentar e nutricional? Por quê?

14. Que sugestões você faria para ampliar a institucionalidade do SISAN? 


\section{Anexo 2 - Plano Avaliativo das Entrevistas}

Objetivo: aferir ser a institucionalidade conferida ao SISAN é insuficiente para viabilizar a política de SAN em toda a sua abrangência (dimensão estrutural e dimensão ideológica) nacionalmente. (Ideias/Méritos/Fragilidades/Desafios/Ausências/Influência dos atores)

\begin{tabular}{|c|c|c|c|}
\hline $\begin{array}{l}\text { ORGANIZAÇÃO DO } \\
\text { SISTEMA }\end{array}$ & IDEIAS/MERITOS & $\begin{array}{l}\text { Coerência da organização do SISAN } \\
\text { com princípios e diretrizes }\end{array}$ & $\begin{array}{l}\text { 1. Considerando a abrangência do conceito de SAN como você define a organização do Estado brasileiro para promover a } \\
\text { SAN? Identifique fatores que facilitam e dificultam essa operacionalização. } \\
\text { 2. } \\
\text { 2. O SISAN e a PNSAN são marcos legais para a SAN. Quais elementos positivos e negativos você destaca na } \\
\text { implementação do SISAN, considerando o período de } 2004 \text { a } 2014 \text { ? } \\
\text { 3. Em sua opinião, em uma escala de } 0 \text { a } 5 \text { como você classifica a relevância de seus princípios e diretrizes para a } \\
\text { institucionalidade de SAN Por quê? }\end{array}$ \\
\hline $\begin{array}{l}\text { COORDENAÇÃO DO } \\
\text { SISTEMA }\end{array}$ & DESAFIOS & $\begin{array}{l}\text { Construção de Arranjos institucionais; } \\
\text { Instrumentos de gestão para } \\
\text { observância de princípios e diretrizes. }\end{array}$ & 4. Como você define a atuação do governo federal enquanto coordenador do SISAN na promoção da intersetorialidade? \\
\hline $\begin{array}{l}\text { CAPACIDADE DE } \\
\text { ARTICULAÇÃO DO } \\
\text { SISTEMA }\end{array}$ & $\begin{array}{c}\text { ATORES E } \\
\text { SETORES DE } \\
\text { INFLUENCIA } \\
\text { E } \\
\text { AUSENCIAS DE } \\
\text { ATORES }\end{array}$ & $\begin{array}{l}\text { Influência na Agenda; } \\
\text { Horizontalidade; Compartilhamento } \\
\text { da gestão e Informação. }\end{array}$ & 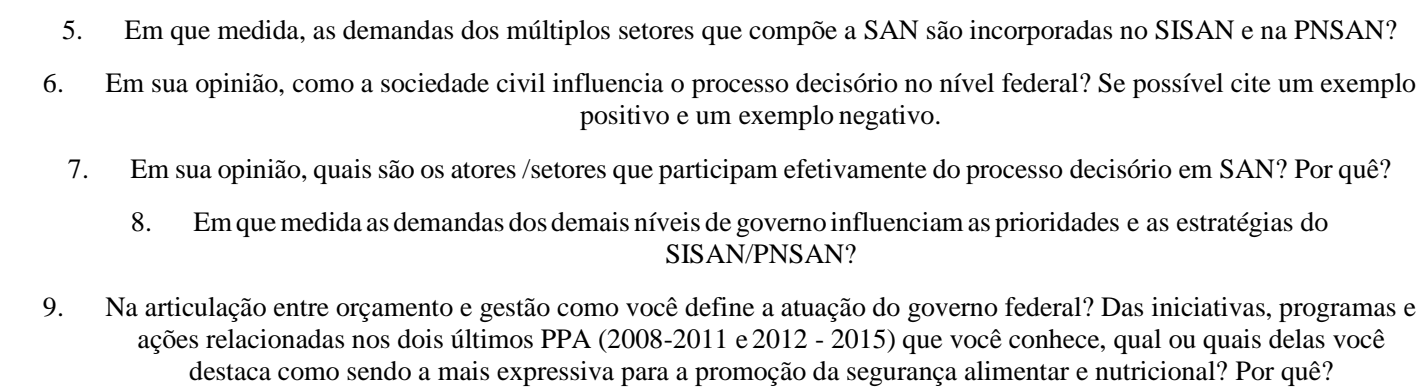 \\
\hline $\begin{array}{c}\text { CONTEXTOS DE } \\
\text { IMPLEMENTAÇÃO }\end{array}$ & FRAGILIDADES & $\begin{array}{l}\text { Déficits políticos conjunturais e outros } \\
\text { que impactam a Implementação. }\end{array}$ & 10. Que sugestão faria para aumentar a institucionalidade do SISAN/PNSAN? \\
\hline
\end{tabular}

Elaborado pela autora. 